Mara Gilene Alves de Carvalho

\title{
ESTRATÉGIA AMBIENTAL PRÓ-ATIVA: SEQÜENCIAMENTO DE LAVRA CONCOMITANTE COM A DISPOSIÇÃO DE ESTÉRIL DENTRO DA MINA
}


Mara Gilene Alves de Carvalho

\title{
ESTRATÉGIA AMBIENTAL PRÓ-ATIVA: SEQÜENCIAMENTO DE LAVRA CONCOMITANTE COM A DISPOSIÇÃO DE ESTÉRIL DENTRO DA MINA
}

\author{
Dissertação apresentada à Escola \\ Politécnica da Universidade de São \\ Paulo para obtenção do título de \\ Mestre em Engenharia Mineral
}


Este exemplar foi revisado e alterado em relação à versão original, sob responsabilidade única do autor e com a anuência de seu orientador.

São Paulo, 27 de abril de 2009.

Assinatura do autor Mone coman

Assinatura do orientador

\section{FICHA CATALOGRÁFICA}

Carvalho, Mara Gilene Alves de

Estratégia ambiental pró-ativa: seqüenciamento de lavra concomitante com a disposição de estéril dentro da mina / M.G.A. de Carvalho. -- ed.rev. -- São Paulo, 2009.

$111 \mathrm{p}$.

Dissertação (Mestrado) - Escola Politécnica da Universidade de São Paulo. Departamento de Engenharia de Minas e de Petróleo.

1. Mineração 2. Meio ambiente I. Universidade de São Paulo. Escola Politécnica. Departamento de Engenharia de Minas e de Petróleo II. t. 
Mara Gilene Alves de Carvalho

\title{
ESTRATÉGIA AMBIENTAL PRÓ-ATIVA: SEQÜENCIAMENTO DE LAVRA CONCOMITANTE COM A DISPOSIÇÃO DE ESTÉRIL DENTRO DA MINA
}

\author{
Dissertação apresentada à Escola \\ Politécnica da Universidade de São \\ Paulo para obtenção do título de \\ Mestre em Engenharia Mineral \\ Área de Concentração: \\ Engenharia Mineral \\ Orientador: \\ Prof. Dr. Giorgio de Tomi
}


A minha família, mãe Gileusa e irmãs, Françoane e Francely, pela força direcionada nos momentos mais díficeis. 


\section{AGRADECIMENTOS}

Aos colegas do curso, pela amizade e apoio.

À colega Evangelina Apparício, pela força inicial que impulsionou o mestrado.

Ao colega de trabalho e amigo, Flávio Ferreira, pelo meu aprendizado profissional e colaboração.

Ao meu orientador, Giorgio de Tomi, pelo apoio e abertura das portas para o mestrado.

Aos amigos, pelo eterno aprendizado.

À VALE, pela confiança depositada e pela oportunidade proporcionada. 


\section{RESUMO}

Este trabalho propõe uma metodologia inovadora de seqüenciamento de lavra em minério de ferro a qual, além de considerar os parâmetros operacionais e econômicos das técnicas tradicionais, permite uma abordagem ambiental proativa para sequenciar a lavra de forma a antecipar a exaustão de parte da cava para disposição do estéril dentro da cava final. A metodologia proposta de seqüenciamento ordenado de lavra permite reduzir a área degradada a ser reabilitada na mina, com significativos benefícios associados à reducão do impacto ambiental, sem comprometer as metas de produtividade e competitividade econômica da lavra. A metodologia de seqüenciamento ordenado de lavra foi aplicada em um estudo de caso de projeto de lavra de minério de ferro, e os resultados alcançados comprovaram os benefícios esperados com a aplicação da metodologia proposta.

Palavras-chave: Seqüenciamento de Lavra. Impacto Ambiental da Mineração. Lavra a Céu-Aberto. Minério de Ferro. 


\begin{abstract}
This paper presents a innovative approach for an environmentally pro-active mine scheduling process. The proposed methodology has been developed for identifying a mine sequence that meets all operational and economical constraints in iron-ore mining, and takes into account a pro-active approach for scheduling the mine according to environmental criteria. The proposed methodology allows a significant reduction of the environmental impact related to the mining operation without compromising productivity and the economical feasibility of the mine. The methodology has been applied to a case study of iron ore mining in Brazil, where the expected benefits have been proven.
\end{abstract}

Keywords: Mine Scheduling. Mining Environmental Impact. Open Pit Mining. Iron Ore Mining. 


\section{LISTA DE ILUSTRAÇÕES}

Figura 1 - Croqui sem escala da vista em perspectiva do modelo geológico de blocos.

Figura 2 - Fluxograma do método dos cones flutuantes 18

Figura 3 - Exemplo de custos e receitas dentro do processo produtivo 21

Figura 4 - Croqui sem escala dos drenos 35

Figura 5 - Croqui sem escala da fase de lançamento do método descendente .......36

Figura 6 - Croqui sem escala da fase de lançamento do método ascendente ..........37

Figura 7 - Croqui sem escala dos sistemas de drenagens 41

Figura 8 - Fluxograma da metodologia geral do planejamento de lavra. 45

Figura 9 - Fluxograma da metodologia específica do seqüenciamento de lavra ordenado 47

Figura 10 - Figura ilustrativa da localização do projeto ferro Carajás 49

Figura 11 - Mapa de localização dos principais platôs da província mineral em

Carajás .50

Figura 12 - Minas de ferro em lavra atualmente no sistema norte.

Figura 13 - Imagem Ikonos de Serra Sul mostrando o platô do alvo S11 e a

subdivisão dos corpos. .53

Figura 14 - Máficas encontradas na jazida de Serra Sul 54

Figura 15 - Tipos de rochas ricas em ferro encontradas na jazida de Serra Sul ......55

Figura 16 - Diagrama ilustrativo da função benefício ...........................................58

Figura 17 - Croqui sem escala da cava operacionalizada de Serra Sul ..................61

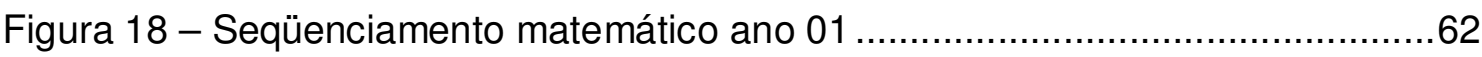

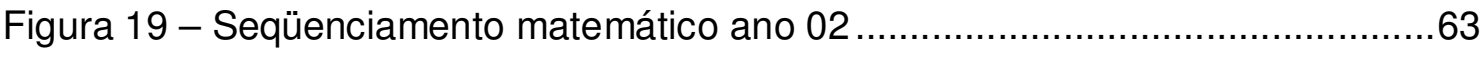

Figura 20 - Gráfico da evolução da SiO2 no seqüenciamento matemático ...............64

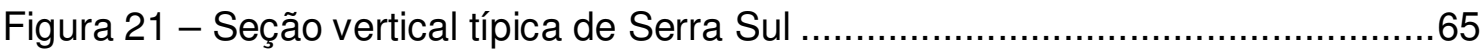

Figura 22 - Seção vertical típica de Serra Sul ....................................................66

Figura 23 - Malha de sondagem nos corpos C e D do alvo S11 ….......................67

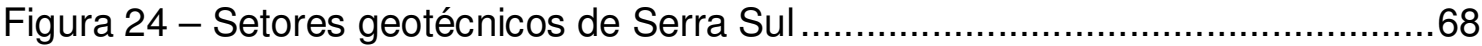

Figura 25 - Cava de Serra Sul dividida por áreas ...............................................69

Figura 26 - Indicativo de onde será o ínicio da lavra de Serra Sul ..........................70

Figura 27 - Croqui sem escala do plano de lavra ano 15 ....................................72 
Figura 28 - Croqui sem escala do plano de lavra e disposição de estéril ano 15 .....72 Figura 29 - Croqui sem escala da geometria dos depósitos de estéril 01, 02 e 03 ..76 Figura 30 - Croqui sem escala ano 15 (2025) lavra concomitante com a disposição de estéril dentro da mina 78

Figura 31 - Croqui sem escala ano 20 (2030) lavra concomitante com a disposição de estéril dentro da mina. 79

Figura 32 - Croqui sem escala da área calculada em hectares para disposição de estéril. 82

Figura 33 - Polígono da área calculado para dispor estéril dentro da cava..............83

Figura 34 - Seção com blocos do modelo econômico …………………………....90

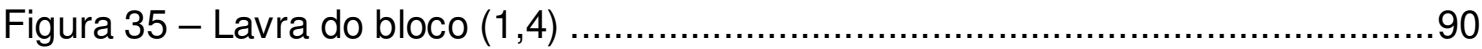

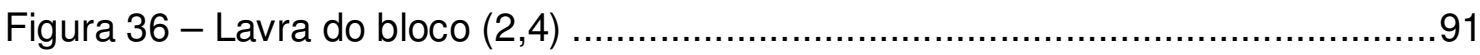

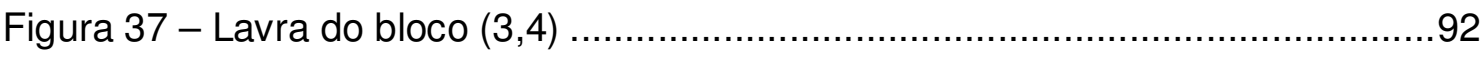

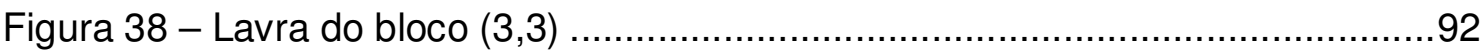

Figura 39 - Configuração Cava Final - Cones Flutuantes .....................................93

Figura 40 - Acumulação dos valores econômicos dos blocos .................................94

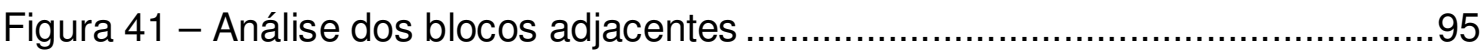

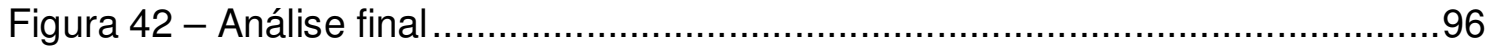

Figura 43 - Configuração da cava final - Lerchs Grossmann.................................96

Figura 44 - Croqui sem escala da topo primitiva ……........................................99

Figura 45 - Croqui sem escala da topo primitiva com limite da cava.....................100

Figura 46 - Croqui sem escala do plano de preparação da lavra ............................101

Figura 47 - Croqui sem escala do plano de lavra ano 01 (2011) ..........................102

Figura 48 - Croqui sem escala do plano de lavra ano 02 (2012) .........................103

Figura 49 - Croqui sem escala do plano de lavra ano 03 (2013) .........................104

Figura 50 - Croqui sem escala do plano de lavra ano 05 (2015) .........................105

Figura 51 - Croqui sem escala do plano de lavra ano 07 (2017) .........................106

Figura 52 - Croqui sem escala do plano de lavra ano 10 (2020) ..........................107

Figura 53 - Croqui sem escala do plano de lavra ano 15 (2025) ..........................108

Figura 54 - Croqui sem escala do plano de lavra e disposição de estéril ano 15

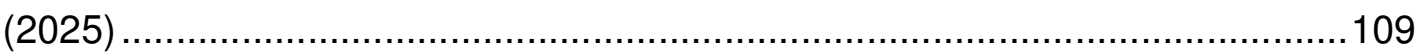

Figura 55 - Croqui sem escala do plano de lavra ano 20 (2030) ........................110

Figura 56 - Croqui sem escala do plano de lavra e disposição de estéril ano 20 (2030) 


\section{LISTA DE TABELAS}

Tabela 1 - Parâmetros geotécnicos com base no tipo de material .........................56

Tabela 2 - Descrição dos domínios geológicos e ângulos de taludes .....................57

Tabela 3 - Plano de produção da lavra................................................... 73 


\section{LISTA DE ABREVIATURAS E SIGLAS}

$\begin{array}{ll}\text { CARAJÁS } & \text { Província Mineral no Sul do Pará } \\ \text { DIPM } & \text { Diretoria de Desenvolvimento de Projetos Minerais } \\ \text { DIPF } & \text { Diretoria de Planejamento e Desenvolvimento de Ferrosos } \\ \text { DMT } & \text { Distância Média de Transporte } \\ \text { FLONACA } & \text { Floresta Nacional de Carajás } \\ \text { MINESIGHT } & \text { Software de Planejamento de Mina intitulado Minesight } \\ \text { NPV } & \text { Software de Planejamento de Mina intitulado NPV } \\ \text { N4E } & \text { Mina em lavra atualmente em Carajás } \\ \text { N4WN } & \text { Mina em lavra atualmente em Carajás } \\ \text { N5E } & \text { Mina em lavra atualmente em Carajás } \\ \text { N5EN } & \text { Mina em lavra atualmente em Carajás } \\ \text { N5W } & \text { Mina em lavra atualmente em Carajás } \\ \text { RE/M } & \text { Relação estéril minério } \\ \text { ROCKTYPE } & \text { Tipo litológico }\end{array}$




\section{SUMÁRIO}

1 INTRODUÇÃO........................................................................13

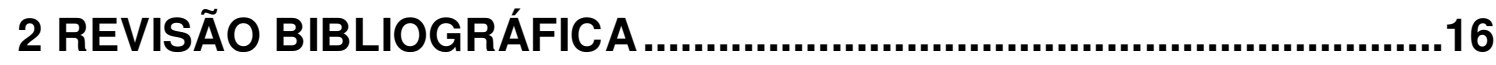

2.1 PRINCIPAIS TÉCNICAS PARA GERAÇÃO DE CAVA ..........................16

2.2 PRINCIPAIS TÉCNICAS PARA GERAÇÃO DE SEQÜENCIAMENTO DE

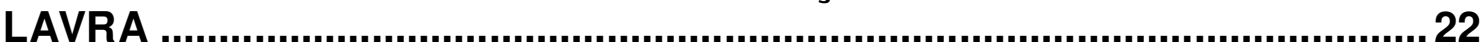

2.3 DISPOSIÇÃO DE ESTÉRIL DE MINA E REJEITO_..................................25

2.4 GERENCIAMENTO AMBIENTAL DE OPERAÇÕES MINEIRAS.............. 28

2.5 DISPOSIÇÃO EM CAVA..................................................................31

2.6 ELABORAÇÃO DE PROJETO DE ESTÉRIL, EM PILHA, EM MINERAÇÃO........................................................................................... 33

2.6.1 Desmatamento e Procedimentos Iniciais ................................................34

2.6.2 Método Descendente ...........................................................................36

2.6.3 Método Ascendente ...............................................................................36

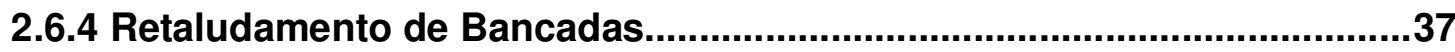

2.6.5 Sistema de Drenagem ...............................................................................38

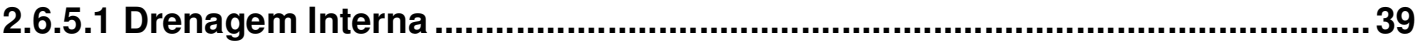

2.6.5.2 Drenagem Superficial............................................................................. 39

2.6.5.3 Drenagem Periférica ............................................................................... 40

2.6.6 Planejamento de diques de contenção de finos.....................................42

3 METODOLOGIA DO TRABALHO ...................................................43

3.1 DADOS E RECURSOS UTILIZADOS …....................................................43

3.2 METODOLOGIA GERAL DO PLANEJAMENTO DE LAVRA ..................44

3.3 METODOLOGIA ESPECÍFICA DO SEQÜENCIAMENTO DE LAVRA

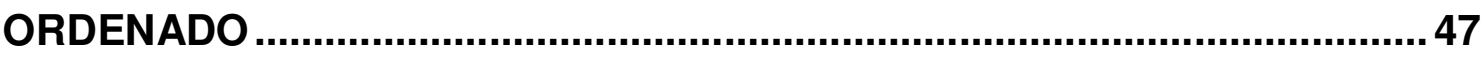

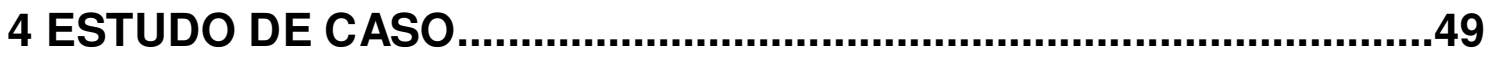

4.1 CARACTERIZAÇÃO DAS MINAS DE FERRO DE CARAJÁS NO SISTEMA NORTE

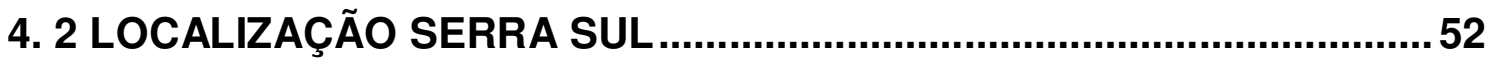

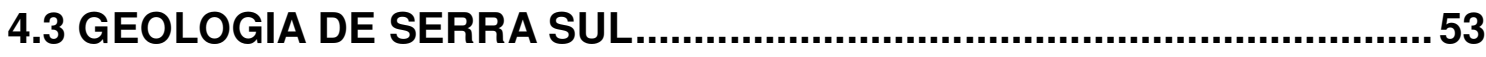




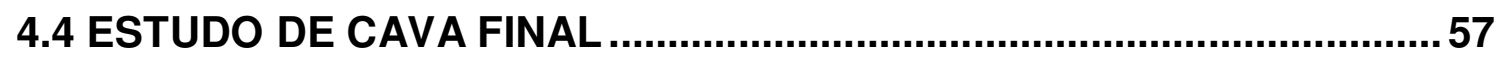

4. 5 SEQÜENCIAMENTO DE LAVRA ..................................................61

4.5.1 Seqüenciamento Matemático ................................................................61

4.5.2 Análise da geologia local......................................................................65

4.5.3 Análise da malha de sondagem ...........................................................66

4.5.4 Estudo geotécnico ...................................................................................67

4.5.5 Avaliação por área da cava .................................................................69

4.5.6 Seqüenciamento de lavra ordenado ..................................................70

4.6 DEPÓSITO DE ESTÉRIL ................................................................... 74

4.6.1 Depósito de estéril convencional..........................................................74

4.6.2 Depósito de estéril dentro da cava ..................................................... 78

5 RESULTADOS ..............................................................................81

5.1 QUANTITATIVO DA REDUÇÃO EM HECTARES DA ÁREA

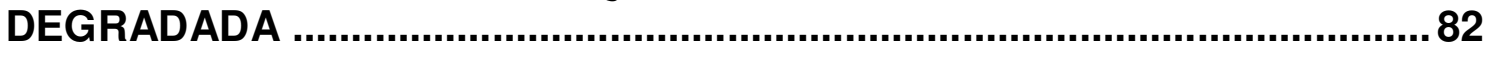

6 CONCLUSÕES............................................................................84

6.1 RECOMENDAÇÕES DE CONTINUIDADE DO TEMA DE PESQUISA ... 84 REFERÊNCIAS BIBLIOGRÁFICAS .............................................86

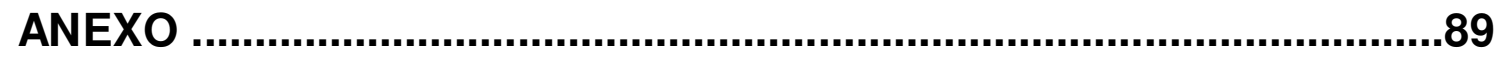




\section{INTRODUÇÃo}

O desafio do seqüenciamento de lavra de uma mina a céu aberto é normalmente associado à necessidade de atender as metas de produção e lucratividade durante toda a vida útil da mina, além de obedecer às restrições geotécnicas e operacionais de lavra como a estabilidade de taludes, gerenciamento da frota de carga e transporte, e o controle da variabilidade dos teores na alimentação da usina.

As técnicas de seqüenciamento de lavra mais amplamente utilizadas pelos especialistas em planejamento de mina incluem as técnicas heurísticas e a análise de parametrização econômica do depósito. Estas técnicas de seqüenciamento têm evoluído constantemente para atender os diferentes requisitos da indústria mineral e as especificidades de bens minerais variados, desde minérios metálicos de alto valor, como ouro, cobre e platina, até minerais industriais como calcário para cimento e argilas para a indústria cerâmica.

No entanto, além dos parâmetros técnicos e econômicos, uma demanda que tem sido progressivamente exigida no seqüenciamento de lavra é o atendimento das restrições ambientais da mina. A partir da década de 70, a proteção ambiental passou a ter maior importância na tomada de decisões de seqüenciamento de lavra, o que provocou sérias transformações na indústria mineral. Essa evolução gerou uma mudança de visão em relação ao papel da mineração na sociedade: a atividade mineral passou a ser entendida como uma forma de uso temporário do solo, e não de uso final, como era no passado (Oliveira, 2001).

Por outro lado, na última década, houve um aumento significativo da demanda global de bens minerais e, em particular, de minério de ferro. Esse fato desencadeou diversos esforços para aumento da capacidade produtiva do setor mineral, tanto em termos de infra-estrutura de produção, quanto na identificação de novos recursos minerais. Neste contexto, há a necessidade de expansão da produção das minas em operação além da abertura de novos projetos de minério de ferro. 
Expandir uma mina em operação ou abrir uma nova normalmente significa ampliar a quantidade de estéril a ser lavrada, de forma a liberar recursos adicionais de minério. O desafio para o seqüenciamento de lavra nesses casos é planejar a expansão dos projetos de disposição de estéril, tanto em depósitos já existentes, quanto em novos depósitos de estéril.

Todo novo projeto de mineração ou qualquer revisão ou expansão requer a aprovação dos órgãos gestores do meio-ambiente, que no Brasil passa pelo procedimento de licenciamento da implantação e da operação de todas as instalações da mina. Assim, todo novo projeto ou mudança nos projetos de disposição de estéril também depende de licenciamento ambiental. Essa situação introduz incertezas adicionais no seqüenciamento de lavra, uma vez que a disposição de estéril através da expansão dos depósitos atuais ou através de novos projetos dependerá da aprovação de todo o procedimento legal de licenciamento de implantação em tempo hábil para atender as necessidades do plano de lavra.

Neste contexto, o principal objetivo desse trabalho é apresentar uma metodologia inovadora de seqüenciamento de lavra em minério de ferro a qual, além de considerar os parâmetros operacionais e econômicos das técnicas tradicionais, permita levar em conta uma abordagem ambiental proativa para seqüenciar a lavra de forma a antecipar a exaustão de parte da cava visando a disposição do estéril dentro da cava final.

Os principais aspectos estratégicos introduzidos pela metodologia proposta são:

- Aperfeiçoamento do processo de reabilitação de áreas degradadas na mina;

- Diminuição considerável da área degradada nos entornos da operação, com redução significativa dos impactos ambientais na região;

- Possibilidade de disposição do estéril na mesma cava com redução significativa da DMT ("Distância Média de Transporte") da mina e consequente aumento da produtividade; 
- Redução da degradação de áreas virgens que eventualmente seriam necessárias para a disposição do estéril adicional;

- Redução de obras de infraestrutura para a construção de diques e drenos de fundo de novos depósitos de estéril;

- Eliminação de riscos de ruptura de taludes, já que parte do estéril será depositado de forma confinada dentro da cava exaurida;

- Redução de custos com estudos geotécnicos, hidrogeológicos, ambientais, de licenciamento e de descomissionamento de área para os novos depósitos de estéril.

Embora a utilização de cavas exauridas para depósito de estéril seja uma prática comum em alguns métodos de lavra, como por exemplo, a lavra em tiras (Kennedy, 1990), este trabalho propõe uma metodologia de seqüenciamento de lavra que antecipa a exaustão de áreas estratégicas da mina para dispor estéril enquanto a lavra continua em outras áreas. 


\section{REVISÃO BIBLIOGRÁFICA}

\subsection{PRINCIPAIS TÉCNICAS PARA GERAÇÃO DE CAVA}

A cava final é definida como sendo aquela na qual, caso a remoção de todo o minério e de todo o estéril pudessem ser feitas de uma só vez, resultaria no lucro máximo.

Todos os algorítimos atualmente em uso para a determinação da cava final trabalham com o conceito de modelo de blocos, o qual foi desenvolvido, segundo Girodo; Campos e Valente (2000) na década de 60 pelos mineradores de cobre do sudeste americano.

A Figura 1 apresenta uma vista em perspectiva de um modelo de blocos.

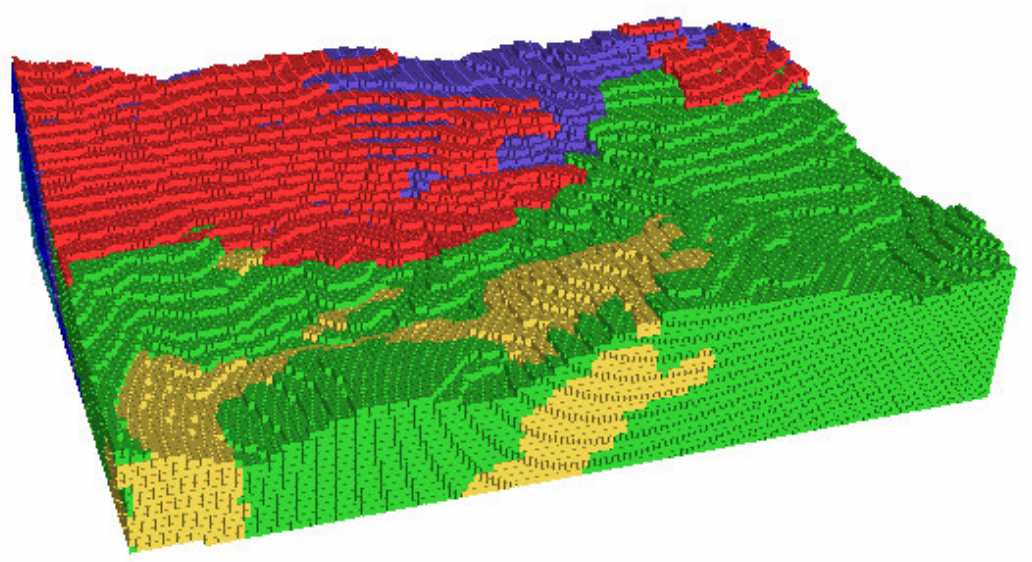

Figura 1 - Croqui sem escala da vista em perspectiva do modelo geológico de blocos Fonte - Carvalho e De Tomi, 2009

Segundo Chausson; De Tomi e Azevedo (2001) o modelo de blocos contém informações de natureza diversa, mas intimamente ligadas à jazida em questão, como teores das substâncias constituintes do bem mineral, ângulos de talude por setor da jazida, características geomecânicas das rochas, valores de cada bloco calculados segundo uma função benefício. 
A elaboração de um modelo de blocos consistente com as observações verificadas no campo é uma das etapas mais complexas na modelagem geológica e planejamento de lavra de uma jazida mineral, é de importância vital para a adequada sequência de operações de uma mina.

Recentemente, este processo tornou-se objeto de estudos mais refinados e precisos, uma vez que a correta valorização de um jazimento mineral passou a ser um dos critérios exigidos por bancos e investidores na apreciação do investimento a ser realizado. Em países como a Austrália e os Estados Unidos, a criação de códigos de avaliação de jazidas segundo critérios mais rígidos passou a ser adotada e seguida, com a avaliação de profissionais especialmente capacitados para tal.

Dentro das várias técnicas disponíveis para a determinação da cava final, citaremos as duas principais, cuja utilização e limitações já são comprovadas por engenheiros de planejamento em todo o mundo.

O algorítimo dos cones flutuantes e suas derivações trabalham extraindo seletivamente de um modelo de blocos aqueles blocos que podem ser lavrados com lucro. Para tal, faz-se uma varredura no modelo de blocos com um 'cone invertido', selecionando-se aqueles blocos cujo valor seja capaz de pagar a sua retirada e a do material imediatamente acima do mesmo.

Este algorítimo, embora muito utilizado, mostrou-se incapaz de resolver alguns problemas para a identificação de combinações de blocos que individualmente não poderiam ser lavrados com lucro, mas quando tomados em conjunto obtinham valor suficiente para pagar a sua retirada.

A Figura 2 representa o fluxograma do algoritmo dos cones flutuantes. 


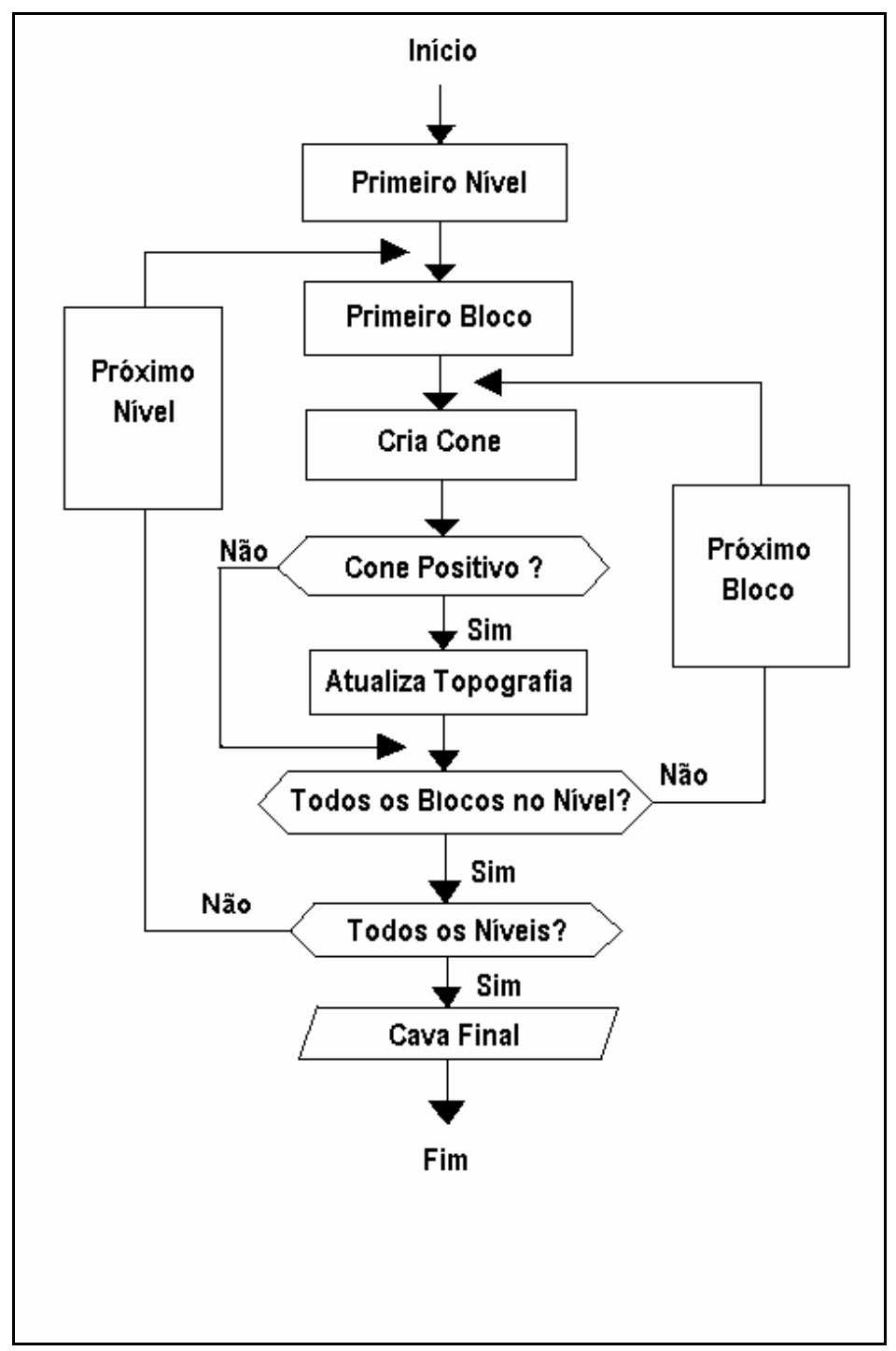

Figura 2 - Fluxograma do método dos cones flutuantes Fonte - Adaptado de Wright, 1990

O fluxograma acima mostra um algoritmo iterativo que consiste na construção de um cone invertido (com as restrições de talude e fundo de cava) que caminha ao longo do modelo econômico de blocos, partindo do topo do modelo. Para cada posição do vértice do cone é calculado o somatório do valor econômico dos blocos que estão em seu interior. Todo cone positivo será lavrado e ao final da simulação todos os cones lavrados constituirão a cava final.

É um dos mais populares métodos devido à facilidade de entendimento, por sua simplicidade, apresentando menor complexidade para sua implementação computacional, em relação aos outros métodos de determinação da cava final. 
Novos desenvolvimentos e modificações têm sido feitos nesta técnica por autores como Yamatomi et al. (1995), a fim de resolver os problemas expostos acima.

Um exemplo de aplicação do método dos cones flutuantes é apresentado no Anexo 01.

O algorítimo de Lerchs-Grossmann, como descrito e provado por ambos em artigo publicado em 1965, tornou-se a referência mundial como a solução matemática do problema de otimização de cavas.

Conforme Whittle (1989), o método trabalha com um modelo de blocos criado a partir de um corpo geológico e progressivamente, constrói matrizes de blocos relacionados que devem, ou não serem lavrados. A matriz final define um contorno da cava que tem o maior valor possível, levando-se em conta os requisitos dos ângulos de talude da cava. Este contorno irá incluir todo bloco lavrado, levando-se em conta o estéril removido para acessar o minério. Da mesma forma, também exclui todos os blocos que não devem ser lavrados.

Estes blocos possuem um valor econômico positivo, consistindo do valor do produto recuperável, menos os custos de lavra e processamento, o que compreende o valor do fluxo de caixa líquido do bloco resultante da lavra do mesmo, isoladamente. Os blocos de estéril e ar têm valores negativos e zero, respectivamente.

Segundo Ferreira e De Tomi (2001) a maioria dos métodos de otimização usados com a finalidade da definição do limite econômico de escavação de minas a céu aberto utiliza uma função benefício econômico, que permite que se verifique se a lavra de um bloco complementar a um dado limite de escavação adiciona valor ao limite anterior, ou não.

Bongarçon (1993) classifica os métodos computacionais utilizados na indústria mineral em quatro familias, a saber:

- Método das expansões, variante computacional do tradicional método manual dos avanços; 
- Algoritmos dos cones móveis (também denominado de cones flutuantes ou cones mineradores);

- Teoria dos grafos, popularmente conhecidos como algoritmos de Lerchs \& Grossman;

- Método da parametrização de reservas.

Cada uma destas famílias de métodos computacionais tem produtos comerciais que implementam os respectivos modelos matemáticos, permitindo a modelagem dos parâmetros de engenharia do empreendimento, tais como: configurações dos ângulos de estabilidade dos taludes, rampas, acessos, restrições operacionais, etc.

Eventualmente, são efetuadas comparações entre os vários métodos, que via de regra conduz a resultados semelhantes se a implementação do modelo matemático foi bem executada, conforme exemplificado por Kentwell (2002).

Ainda segundo Bongarçon (1993), todos os métodos citados anteriormente pressupõem a existência de um modelo de blocos computacional contendo o valor econômico de cada bloco individualizado, que é a variável a ser maximizada no processo de otimização.

A Figura 3 exemplifica os custos relacionados ao valor econômico de cada bloco do modelo. 


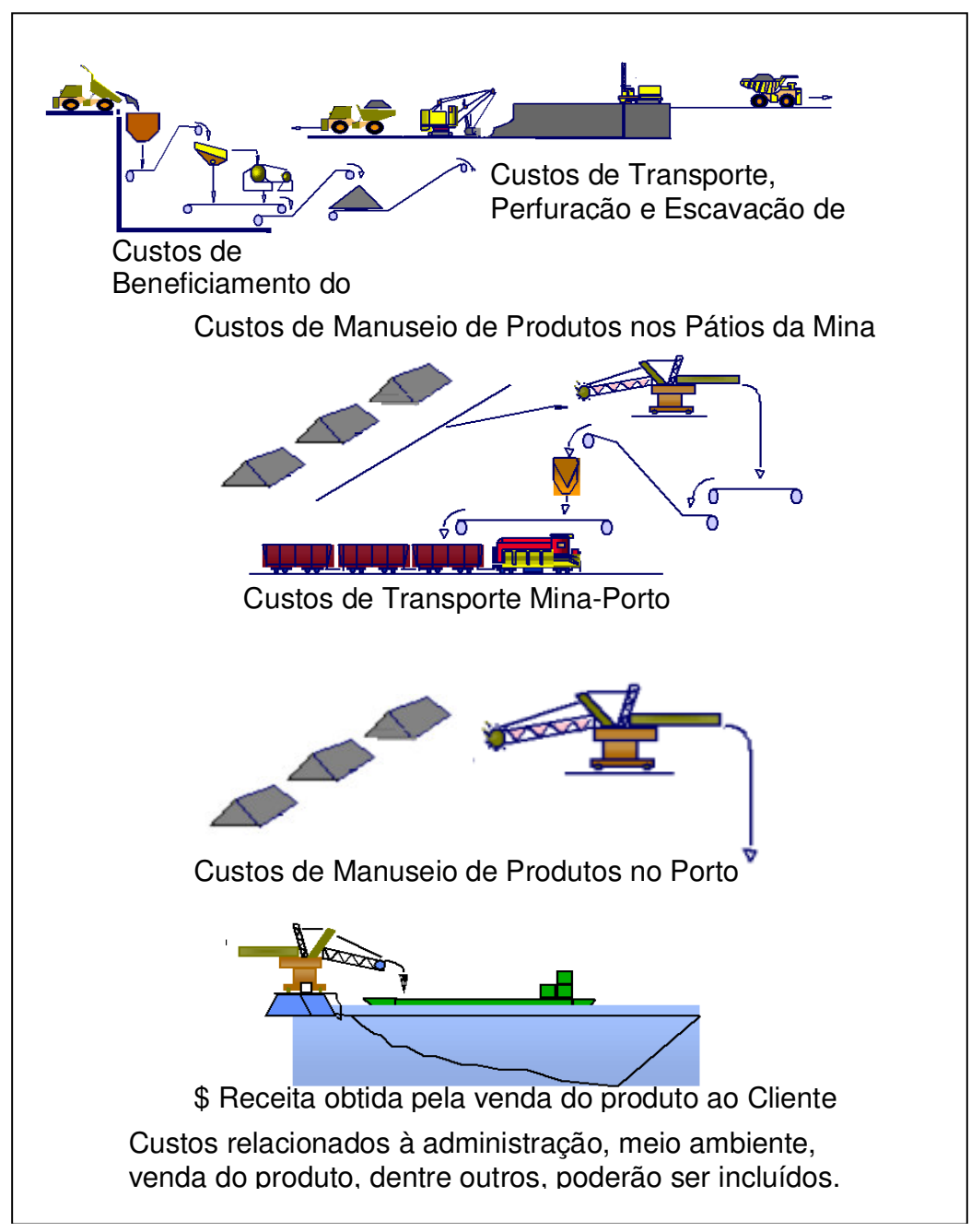

Figura 3 - Exemplo de custos e receitas dentro do processo produtivo Fonte - Silva, 2003

Quando há restrições de qualidade definindo as condições de contorno dos problemas de otimização, os modelos matemáticos supracitados conduzem a resultados ótimos se existirem funções de correlação entre os parâmetros de qualidade utilizados e a função benefício e, além disso, as referidas funções puderem ser aplicadas a cada bloco individual do modelo de blocos computacional. Desta forma, alguns blocos que não atenderem à função de correlação dos parâmetros de qualidade terão benefícios negativos e serão considerados como blocos estéreis.

No Anexo 02 é apresentado um exemplo da aplicação do algoritmo por programação dinâmica em 2D. 


\subsection{PRINCIPAIS TÉCNICAS PARA GERAÇÃO DE SEQÜENCIAMENTO DE LAVRA}

O seqüenciamento de lavra convencional parte do princípio de que uma cava final é inicialmente encontrada por alguma metodologia e a partir da mesma, a sequência de extração será desenvolvida.

Segundo Chausson; De Tomi e Azevedo (2001), diversas discussões têm versado em torno deste tema, as quais têm questionado a utilização de resultados que priorizam a maximização do lucro, ou do metal contido em detrimento da seqüência ótima de extração, que seria obtida com a disponibilização de um material de características constantes para a planta de beneficiamento. Tais discussões levaram à elaboração de técnicas alternativas, como será visto no próximo item, que tentam equacionar de forma mais dinâmica e adequada tanto os aspectos de otimização e seqüenciamento quanto os de caráter operacional de uma mineração.

A seguir são apresentadas as principais técnicas de seqüenciamento disponíveis na literatura:

Heurístico de Gershon

A técnica Heurística descrita por Gershon (1982) utiliza o conceito de blocos com "pesos posicionais" para determinar quando um bloco deve ser lavrado. O peso posicional de um bloco advém da geração de um cone decrescente do bloco até a extremidade da cava final e da soma dos valores de todos os blocos naquele cone. O valor resultante fornece uma medida da necessidade de remover um dado bloco naquele ponto no tempo. Ele reflete a qualidade do minério e a posição do bloco e a qualidade do minério sobre certo bloco.

Para efetuar o seqüenciamento, os pesos posicionais para todos os blocos na cava são ordenados e uma seleção é feita a partir dos blocos de valor mais alto. Este procedimento é repetido até que todos os blocos na cava final tenham sido extraídos. 


\section{Análise Paramétrica}

Lerchs e Grossmann (1965) reconheceram que ter um contorno ótimo para uma cava final não era de muita utilidade sem uma boa sequência de extração para produzi-lo. Para satisfazer este requisito, eles introduziram o conceito de análise paramétrica, na qual o desenvolvimento de uma cava é caracterizado pela modificação gradual em um ou mais de seus parâmetros-chave.

Fazendo isto, Lerchs e Grossmann estavam procurando produzir uma sequência de extração a qual iria maximizar o fluxo de caixa integral com relação ao volume total lavrado.

Estabelecendo-se que não haja excessivas interdependências entre regiões de minério e estéril, o resultado final é uma série de cavas endentadas/aninhadas que podem ser usadas para determinar uma sequência apropriada de extração. A técnica é, portanto conhecida como o algoritmo endentado de Lerchs-Grossmann.

Infelizmente, se estas condições são apenas parcialmente satisfeitas, o salto entre cavas endentadas consecutivas pode ser tão largo que ele impede a aplicação efetiva das cavas endentadas para o processo da sequência de extração. De fato, sob condições 'corretas', também é possível saltar de nenhuma cava para a cava final em um único incremento. Isto é comumente conhecido como o problema do "salto" (gap problem).

Matheron (1975a e 1975b), François-Bongarçon e Guibal (1984) e Coleau (1988) expandiram mais tarde estas idéias para incluírem a parametrização técnica, tanto quanto a econômica, do depósito.

Este método foi desenvolvido no Centro de Geoestatística da Escola de Minas de Paris entre 1975 e 1976, e foi pioneira e inovadora na solução do problema de definição da cava final. O modelo das técnicas anteriores passa, necessariamente, pela avaliação conjunta técnico/econômica para encontrar a cava ótima. Nesta metodologia ocorre uma completa desvinculação da análise técnica (questão geométrica) da econômica. 
Simplificadamente, a técnica parte do princípio que todas as cavas possíveis podem ser descritas em função de três parâmetros básicos: a tonelagem de minério $(T)$, a quantidade de metal contido (Q) e a tonelagem total (V).

Heurístico de Wang e Sevim

Wang e Sevim (1992) utilizaram o conceito de cones invertidos de Gershon no desenvolvimento do seu algorítmo heurístico. Entretanto, sua aproximação não requeria que uma cava final tivesse sido determinada inicialmente. O heurístico começava pela determinação da maior cava que iria satisfazer tanto os requisitos de ângulos de talude quanto se ajustar dentro dos limites das bordas externas.

A seguir ele prossegue ordenando uma lista de cones adequados por seus teores médios e remove uma quantidade suficiente dos cones com teores mais baixos para satisfazer o tamanho dos incrementos de cava necessários. Este procedimento é repetido até que nenhum bloco reste para ser extraído. Desta forma, uma série de cavas incrementais é gerada, as quais não apresentam o problema dos "saltos" evidentes de outras análises paramétricas. Wang e Sevim reinvindicam que eles obtiveram parametrizações que são muito próximas daquelas produzidas pelo algorítimo de cavas endentadas de Lerchs-Grossmann.

No entanto, o Heurístico de Wang e Sevim sofre das seguintes limitações:

1. Como foi o caso para as primeiras implementações dos cones flutuantes, ele não é capaz de lidar propriamente com os efeitos dos cones sobrepostos;

2. Devido ao fato de que os incrementos de lavra são gerados em uma ordem contrária à qual eles devem necessariamente ser lavrados, fica mais difícil incorporar limitações adicionais do processo de seqüenciamento;

3. O seqüenciamento de lavra produzido não necessariamente será aquele que maximiza o NPV da mina.

Entretanto, ele aparenta ter sido, no final, parcialmente bem sucedido ao derivar uma cava e um seqüenciamento de lavra consecutivamente com um tempo de processamento aceitável. 


\subsection{DISPOSIÇÃO DE ESTÉRIL DE MINA E REJEITO}

As atividades de mineração geram uma grande quantidade de estéreis na mina e de rejeito na planta de beneficiamento. $\mathrm{Na}$ classificação granulométrica desses materiais tem-se desde estéril grosseiro de mina até argila fina, rejeitos de flotação, precipitados químicos e lamas. Tal diversidade de tamanhos dificulta o projeto de construção de áreas para depósitos de estéreis, e no geral, deve-se levar em consideração até as características físicas, químicas e mineralógicas desses rejeitos. A descarga dos estéreis da mina e dos rejeitos da usina de beneficiamento produz uma origem potencial de contaminação do meio ambiente e outros problemas incluindo os seguintes, de acordo com Ritcey (1989):

- A água de mina descarregada nos depósitos de contenção de rejeitos pode conter, em adição ao metal remanescente (que poderia ser recuperado em alguns casos), ácido devido à auto - oxidação ou oxidação bacteriana de sulfetos na mina. Tal ácido, a menos que seja neutralizado antes da disposição, reagirá com os rejeitos para solubilizar mais metais e então produzir possíveis contaminantes. Muitas usinas de beneficiamento estão atualmente recirculando a água de mina para uso no circuito do processo a fim de minimizar o problema. A drenagem ácida da mina provavelmente representa o aspecto mais importante no procedimento para o trato dos rejeitos e estéreis de mina e o impacto mais acentuado destes sobre o meio ambiente;

- Rejeitos podem conter também finos e lamas os quais podem afetar a estabilidade das áreas de depósito dos mesmos. Os rejeitos têm usualmente alguma mineralização remanescente após processamento e podem assim constituir um problema ambiental em potencial;

- Os efluentes do processo podem conter metais e ácidos os quais devem ser neutralizados antes da disposição. Alguns materiais orgânicos ou óleos das operações de lavra ou beneficiamento podem constituir um problema no circuito 
se reciclados, e podem criar problemas também na área de deposição dos rejeitos;

- Os rejeitos que são difíceis para desaguar necessitam de grandes áreas de disposição. Frequentemente uma quantidade de água não pode ser reciclada no processo a menos que dispendiosas áreas para depósito sejam construídas para permitir a difícil drenagem;

- O estéril removido nas operações de mina a céu aberto e subterrânea é frequentemente disposto aleatoriamente em áreas não confinadas.

Os rejeitos e os estéreis gerados na mina/usina de beneficiamento podem ser dispostos de várias formas, segundo Ritcey (1989), tais como:

- Depósitos sobre o solo;

- Usado como enchimento posterior na mina a céu aberto ou subterrânea;

- Disposto em lagos profundos;

- Disposto próximo à praia;

- Processamento para recuperação do metal secundário e então disposição.

Naturalmente cada uma das alternativas tem certas vantagens e desvantagens dependendo do minério em particular, do processo e do local de disposição. Algumas implicações ambientais potenciais de depósitos de rejeitos incluem, de acordo com Ritcey (1989):

- Contaminação de rios por infiltração de águas ácidas contendo alta concentração de metais e outras substâncias;

- Contaminação de rios devido ao carreamento de partículas sólidas das áreas de depósitos pela água superficial;

- Contaminação da água e do ar devido à erosão pelo vento de depósitos de rejeitos secos;

- Possível risco de rompimento catastrófico da barragem e liberação de lamas e outras substâncias; 
- Modificação física e estética do meio ambiente;

- Dificuldade de estabelecimento da cobertura vegetal para permanente estabilização dos rejeitos, devido geralmente à desfavorável condição do solo na presença de rejeito de pirita, ou outros materiais sulfetados;

- A disposição em lagos profundos não tem sido mais uma prática aceitável.

$\mathrm{Na}$ fase de projeto da área de disposição de rejeitos existem muitos fatores, que causam impacto sobre o local selecionado, tais como: o projeto da barragem e o método da descarga do rejeito. Esses fatores incluem a presença de um leito de um rio na área, a geologia e a topografia, o material disponível para a construção da barragem, material de fundação, área e configuração da barragem, dimensionamento da borda livre, provisão para controle da água de infiltração, proteção contra erosão, etc. Fatores como esses, se levados em consideração desde o início, ajudarão a assegurar a estabilidade a longo prazo. Esta deve ser a responsabilidade de cada mineração em prover a engenharia e o projeto de áreas seguras para depósito dos rejeitos e seu controle e manutenção. Subsequentemente, a empresa tem a responsabilidade de assegurar a cobertura dos rejeitos, e minimizar poeira e efluentes de contaminação ao meio ambiente. A adequada construção de barragens de rejeitos e estruturas é, portanto, um importante aspecto para conter contaminantes potenciais. Dado que a estrutura deve funcionar igualmente bem, tanto para os efluentes líquidos como para os sólidos, mais atenção é dada para satisfazer seu projeto e construção. Em muitos países a indústria de mineração tem continuamente feito melhorias nos métodos de disposição de estéril, segundo Ritcey (1989).

A superfície das pilhas de estéril é submetida à erosão pela água e pelo vento tanto quanto à reações químicas resultantes da exposição ao ar e a água. Os produtos dessas reações, e os próprios materiais estéreis podem ser espalhados longe do local de origem por forças erosivas. Assim, os contaminantes das pilhas de estéril requerem isolamento do material com relação ao ar e à água, para minimizar a transformação química e a erosão, segundo Ripley; Redmann e Crowder (1996). 
Rejeitos e outros materiais estéreis são altamente susceptíveis à erosão pelo vento se a superfície permanece descoberta e seca, e as partículas são de textura fina, e sua agregação é pequena.

As erosões podem ser muitas e grandes durante os períodos de alta intensidade pluviométrica.

As pilhas de estéril são susceptíveis também ao colapso por frequentes abalos por tremores de terra, e podem também, sob condições estáticas, romperem por causa da liquefação resultante da infiltração da água em aterros. Alguns dos fatores que podem contribuir para essa repentina fluidez dos materiais estéreis são a ausência de drenagem, uma alta tensão de confinamento, e um grande e frequente ciclo de tensões sobre o aterro. Um fator adicional é a natureza do material; a baixa densidade do material, comumente, induz a ocorrência da liquefação do mesmo, segundo Ripley; Redmann e Crowder (1996).

\subsection{GERENCIAMENTO AMBIENTAL DE OPERAÇÕES MINEIRAS}

O gerenciamento ambiental de uma operação de mineração é uma parte integrante dessa operação. Ele pode ser planejado e organizado de maneira que contribua para a realização das metas da empresa incluindo produtividade, qualidade do produto e lucratividade. O desempenho ambiental também é um indicador do direito de cidadania coletivo. Em resumo, o gerenciamento ambiental padrão pode representar uma peça chave na determinação de todo o sucesso de uma operação para acionistas, empregados, comunidade local e o público em geral, de acordo com Higgins (1988).

De modo oposto, um gerenciamento ambiental pouco eficiente, ou a total ausência dele, pode ser responsável por um péssimo desempenho da empresa, ou em algum momento pode decretar a sua falência financeira quando um trabalho dispendioso de recuperação for requerido para satisfazer as obrigações ambientais. 
Por causa desse impacto potencial sobre o sucesso, ou de outro modo, de um novo risco de mineração, problemas ambientais devem ser incorporados dentro do planejamento do projeto. Essa incorporação requer planos para monitoramento ambiental dos impactos projetados.

A incorporação desses problemas de gerenciamento ambiental dentro do planejamento de uma nova mineração deve levar em consideração dois preceitos. Primeiramente, a construção e operação de uma mina, relativas às facilidades de processamento e infraestrutura, não estão livres de quaisquer impactos sobre o meio ambiente; em segundo lugar, o nível de impacto que seja aceitável será fortemente governado pelas particularidades do projeto e suas características geográficas, ecológicas, econômicas e também pela política ambiental.

O ambiente natural tem muitos usos reais para o homem, um dos quais é a assimilação da mineração e dos estéreis industriais. A tarefa do gerenciamento ambiental é fazer o uso sensato da capacidade ambiental em completa consideração de outras demandas dos recursos ambientais, segundo Higgins (1988).

Antes de entrar em operação, uma nova mineração passa por fases distintas de desenvolvimento. Cada fase é categorizada pela ênfase localizada sobre as atividades a serem conduzidas, de maneira que níveis apropriados de informação sejam providos para decisões seguras com referência ao futuro do projeto. As fases podem se sobrepor e não precisam ser contínuas, mas seguir em uma sequência estabelecida.

Se o gerenciamento ambiental é para ser integrado completamente ao projeto, nenhum deslize deve ser cometido anteriormente nem posteriormente ao projeto como um todo, por isso ele deve desenvolver um nível de informação que permita decisões por comparação, segundo Higgins (1988).

$\mathrm{Na}$ fase de projeto conceitual a ordem de magnitude de benefícios, custos, desenvolvimento estratégico e possíveis problemas são estudados, inclusive a identificação de prováveis problemas ambientais. 
No estudo de pré-viabilidade é feita a classificação da mineralização como corpo de minério econômico e exames preliminares econômicos, logísticos e de mercado. Em termos de atividade ambiental, nessa fase é feito o reconhecimento da área com compilação dos dados existentes, definição de restrições e coleta de dados.

O estudo de viabilidade estabelece a extensão e o teor do corpo de minério e a estrutura para desenvolvimento, e onde se verifica a existência ou não de obstáculos insuperáveis. Pela atividade ambiental, são identificados os principais problemas e avaliados com os dados disponíveis; é feita uma previsão dos impactos como gerenciáveis, ou não, e iniciada uma coleta de dados.

Após o estudo de viabilidade é realizado o projeto de engenharia onde são feitas investigações de campo (tais como aquelas relativas à geotecnia e topografia) para projeto, é detalhado o projeto de todas as construções e iniciados contratos e aquisições. Pelo lado ambiental, são estabelecidos detalhes dos fundamentos ambientais, previstos impactos em detalhe, criado o programa de gerenciamento e monitoramento ambiental e incorporados controles ambientais ao projeto.

$\mathrm{Na}$ fase de construção, que vem em seguida, são erguidas as edificações e estabelecido o quadro de pessoal para as operações e os seus procedimentos. $\mathrm{Na}$ atividade ambiental são monitorados os impactos das construções, estabelecido o time para operação, estrutura, programa e equipamentos.

$\mathrm{Na}$ fase de comissionamento, são realizados testes e treinamento para os operadores e são feitas modificações e melhorias. Para as questões ambientais, são executados testes de desempenho dos controles ambientais e monitoramento das descargas iniciais.

Quando em operação, haverá a fabricação de produtos, envio e comercialização dos mesmos. Ambientalmente, acontecerá o monitoramento das operações com informações e controle dos impactos, auditoria e revisão do programa de gerenciamento e monitoramento ambiental, além da preparação para o fechamento da mina. 
Na última fase, que é a de fechamento, as operações são encerradas. Para questão ambiental é hora de limpar o local, assegurar drenagem para estabilidade das construções de mineração no longo prazo, fazer os preparativos para monitoramento e verificações periódicas, segundo Higgins (1988).

\subsection{DISPOSIÇÃO EM CAVA}

Esse método de disposição, tipicamente, dispõe o material estéril dentro de uma cava exaurida de uma mina e dispensa a construção de diques e drenos de fundo, de acordo com Ritcey (1989).

Alguns fatores que devem ser observados a respeito da disposição de estéreis em cava são os seguintes, segundo Ritcey (1989):

- Como na disposição em mina subterrânea, menos material em relação ao que foi removido poderá ser colocado. A diferença em volume é em torno de $25 \%$;

- O método é fácil de projetar e a execução da cobertura assegura erosão mínima e boa drenagem;

- Resulta em poluição mínima do ar;

- Esteticamente o método pode ser agradável;

- A lavra pode ser conduzida concomitante com a colocação do estéril. Usualmente uma pequena cava inicial é usada no estágio inicial da operação;

- Os altos e profundos taludes da cava, por estarem cobertos pelo estéril, têm a área total superficial a ser revegetada minimizada;

- Parâmetros hidrogeológicos considerando migração de contaminantes e infiltração são pobremente entendidos.

Um recente estudo encontrou 40 locais ao redor do mundo dentre os quais se incluem o Canadá, os Estados Unidos, Austrália e Alemanha, segundo Mend (1995), citado por Kuyucak (2001), onde têm sido usadas cavas exauridas de mina a céu 
aberto para a disposição de resíduos tais como: rejeitos, estéril de mina, capeamento de mina, lama e drenagem ácida de mina.

A disposição de estéreis em cava de mineração pode possibilitar um ganho estético e uma melhor reabilitação ambiental em termos de habitat potencial tanto para plantas como animais aquáticos e terrestres, isto em relação aos métodos convencionalmente adotados, de acordo com Mend (1997), citado por Kuyucak, (2001). Os tipos de estéreis incluem os resíduos de processos industriais e lixo urbano. Em adição, têm sido propostas aberturas de cavas com a finalidade de disposição de estéril de mina de urânio.

Como exemplos recentes de projetos de disposição de estéreis em cavas de minas a céu aberto pode-se citar:

- A mina de urânio de Ronneburg, na ex-Alemanha Oriental, explotou em grande escala de produção em subsolo e a céu aberto por aproximadamente 40 anos que resultaram em 113000 toneladas de Urânio e cerca de 200 milhões de metros cúbicos de estéril. Atualmente estes materiais causam risco à saúde humana e fortes impactos ambientais e, portanto exigem ação corretiva. Dentre as opções disponíveis para minorar o enorme passivo ambiental gerado por essa atividade, existe a da disposição desse material na cava exaurida da mina com correção do relevo paisagístico seguido de aplicação de revegetação. O sistema de vegetação adequado, combinado com o sistema de drenagem superficial, provê estabilidade à longo prazo contra erosão e reduz a geração de água ácida, e por meio desse procedimento, se atendem os objetivos principais, que são a redução à exposição radiológica e de emissão de contaminantes à longo prazo. O projeto do sistema de cobertura inclui a avaliação dos critérios e modelos geotécnicos, radiológicos, hidrológicos, geoquímicos e ecológicos, segundo Gatzweiler (2001).

- Outro exemplo é o da pedreira de granito da KWP, em Hong Kong, onde a cava exaurida será preenchida gradativamente por 4,7 milhões de metros cúbicos de capeamento da parte superior da mina em uma operação balanceada de corte e enchimento. O minério está sendo extraído atualmente no nível $125 \mathrm{~m}$ e existe 
uma estrada no nível 190 m, nível até o qual se pretende fazer o enchimento. O enchimento será colocado na cava exaurida com o objetivo de reabilitar a área degradada e manter a estrada para tráfego, que é o objetivo do plano final para essa área de Hong Kong, considerada um dos pontos de referência da cidade.

\subsection{ELABORAÇÃO DE PROJETO DE DEPÓSITOS DE ESTÉRIL EM MINERAÇÃO}

A Associação Brasileira de Normas Técnicas, ABNT, em sua NBR 13029 de julho de 1993, trata no Capítulo 4, intitulado condições específicas, dos parâmetros a serem observados na construção da pilha que são condicionantes relativas à localização da mesma, à sua geometria externa e interna e outros parâmetros que influem na concepção do projeto (NBR 13029, 1993).

Quanto à localização, o material deve ser disposto dentro da própria cava ou o mais

próximo possível da mesma, de preferência em áreas já degradadas, dentro dos limites legais do empreendimento. Deve-se evitar dispor o material em vales com talvegues de inclinação superior a 18; em drenagens, nascentes e cursos d'água; áreas de preservação permanente; terrenos instáveis, alagadiços ou sujeitos a inundação; áreas com vegetação nativa exuberante; áreas com solos férteis.

Quanto à geometria externa e interna da pilha, devem ser observados os seguintes limites e cuidados: altura máxima de bancos de 10 metros; largura mínima de bermas de 6 metros; altura máxima da pilha de 200 metros; existência de acessos para manutenção; reduzir o ângulo entre bancos, para valores inferiores ao ângulo de repouso natural do estéril; bermas com declividade longitudinal e transversal mínimas de 1\% e 5\%, respectivamente; implantação de leiras na crista dos bancos. Atualmente esses valores são dimensionados em função da precipitação pluviométrica da região, das características dos materiais a serem dispostos na pilha, da configuração geométrica da mesma (dependente do local da disposição) e 
das novas exigências dos órgãos ambientais (principalmente ângulos de taludes); não desprezando essas observações de ordem prática.

Os parâmetros adicionais que influem na concepção do projeto são os seguintes: zoneamento interno dos materiais a serem dispostos, de forma a aproveitar ao máximo as características de resistência e drenabilidade de cada um; compatibilização da formação e zoneamento da pilha com as etapas de remoção do estéril; execução da pilha de forma ascendente; proteção dos taludes, preferencialmente com vegetação; remoção e estocagem do solo orgânico da fundação da pilha para aproveitamento futuro; sistemas de drenagem interna, superficial e periférica; sistema de retenção de sedimento oriundo de erosão; sistema de monitoramento.

Houve a revisão dessa norma em outubro de 2006 (NBR 13029, 2006), onde a maior diferença com a norma de 1993 é a altura máxima permitida da pilha que era de 200 metros de altura e na revisão da norma ficou livre esse ítem, onde o fator de segurança mínimo permitido de 1.50 que define a altura máxima da pilha.

\subsubsection{Desmatamento e Procedimentos Iniciais}

As áreas destinadas à lavra devem ser desmatadas conforme as necessidades de desenvolvimento da lavra, abertura de acessos e disposição de estéril. Deve-se proceder a todas estas ações, porém de forma racionalizada e em consonância com o órgão ambiental responsável, conforme o licenciamento.

Antes que se inicie a formação da pilha, deverá ser procedida a limpeza da fundação, que consistirá do desmatamento e destocamento da área, assim como também a remoção do solo superficial, rico em compostos orgânicos que deverá ser re-aproveitado em outras áreas para recobrimento de taludes que serão revegetados. 
A remoção deste solo mole também favorece a estabilidade, pois esta camada pode funcionar como um lubrificante entre a fundação e o material disposto. No fundo dos vales, deverão ser executados os serviços de drenagem e desvio dos cursos d'água existentes. Caso ocorram cursos d'água perenes sob a pilha, os mesmos deverão ser captados e desviados através de tubulações adequadas, ou drenados com blocos de rocha, envolvidos por transições filtrantes.

O conjunto de drenos assume a forma de uma espinha de peixe, com os drenos mestres posicionados ao longo do fundo do talvegue, conforme mostra a Figura 4.

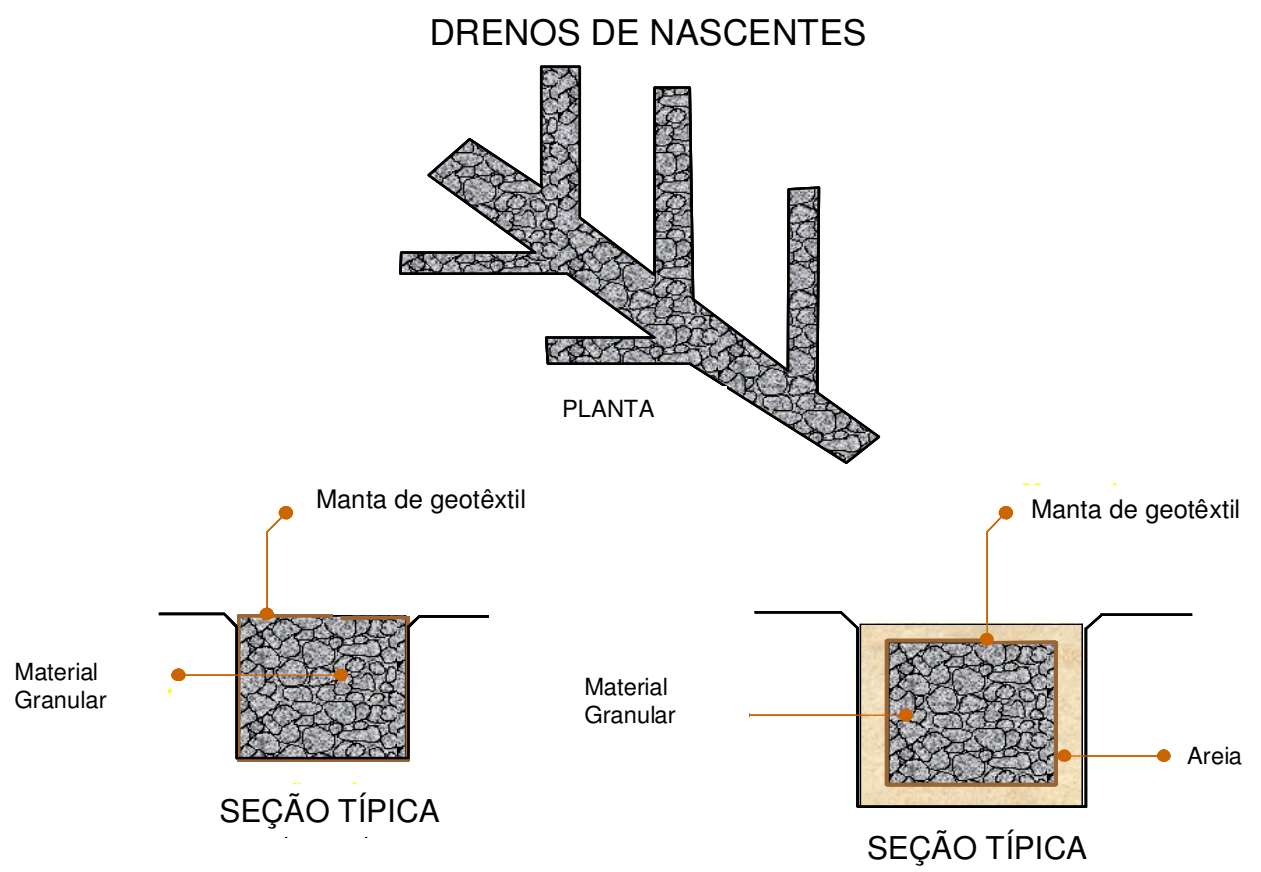

Figura 4 - Croqui sem escala dos drenos

Fonte - Apostila sobre formação de depósito de estéril e rejeito, Relatório interno Vale 2000

Em alguns casos, para aumentar a estabilidade pode ser necessária a execução de um tapete drenante no contato com a fundação, próximo à primeira bancada. Todos os drenos de fundo deverão ser conduzidos até o enrocamento de pé, cuja função é evitar erosões, conforme mostra a Figura 6.

Seguem abaixo os principais métodos de execução de pilhas de estéril:

- Pilhas alteadas pelo método descendente (ponta de aterro);

- Pilhas alteadas pelo método ascendente;

- Contrapilhamento. 


\subsubsection{Método Descendente}

Material lançado em ponta de aterro, sem planejamento ordem ou controle. A pilha é construída em sua altura máxima. Neste caso, o material não sofre compactação e não há preparação da base para o seu recebimento, conforme mostrado na Figura 5.

O método descendente é aparentemente mais econômico, porém não atende às condições mínimas de segurança, podendo causar escorregamento e erosão. Neste método causa danos ao meio ambiente que não são aceitos pelas normas técnicas. O método descendente reduz a distância de transporte, porém o material não adquire compactação, nem apresenta a drenagem adequada. Nos períodos de chuva pode romper e escorregar pela ação da saturação do maciço.

Neste método, não se executa a proteção superficial contra a erosão, ficando o material da superfície não compactado e solto.

Desta forma, durante o período chuvoso estas pilhas irão contribuir com um volume grande de finos para os cursos d'água localizados a jusante. Somente seriam recomendáveis este tipo de pilha onde houvesse uma fundação bastante resistente e o material fosse bastante granulado, permeável.

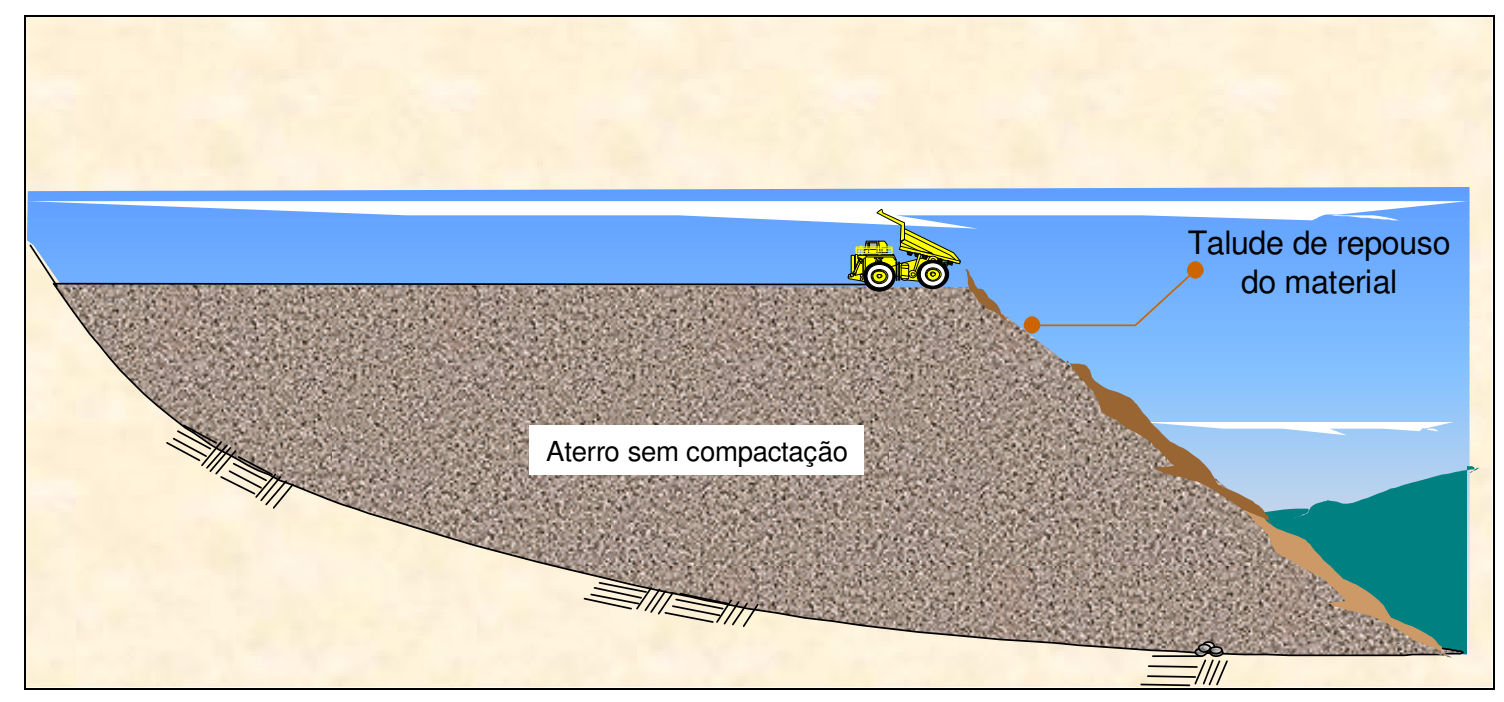

Figura 5 - Croqui sem escala da fase de lançamento do método descendente Fonte - Apostila sobre formação de depósito de estéril e rejeito, Relatório interno Vale, 2000 


\subsubsection{Método Ascendente}

Material transportado e lançado por caminhões, regularizado por tratores ou lançado por correias e regularizado por "scrapers" de forma ordenada, controlada da base do maciço até o topo.

Este método é o mais recomendado pela norma técnica NBR 13029 em vigor, pois contempla todos os procedimentos para maior segurança e estabilidade.

Os bancos deverão ser formados do fundo do vale em direção às cabeceiras, formados pelo basculamento dos caminhões, gerando pilhas individuais com altura de 2 e 3 metros.

Após esta operação, o trator de esteiras deverá quebrar as pilhas, formando uma camada de estéril semi-compactada com a altura de 1 a 1,5m.

O tráfego dos equipamentos provoca compactação no material, suficiente para estabilizar a pilha. As bancadas poderão variar entre 10 e 15 metros de altura. Normalmente as larguras das bermas devem ser superiores a 6 metros, largura mínima aceita pela norma padrão, Figura 6 a seguir.

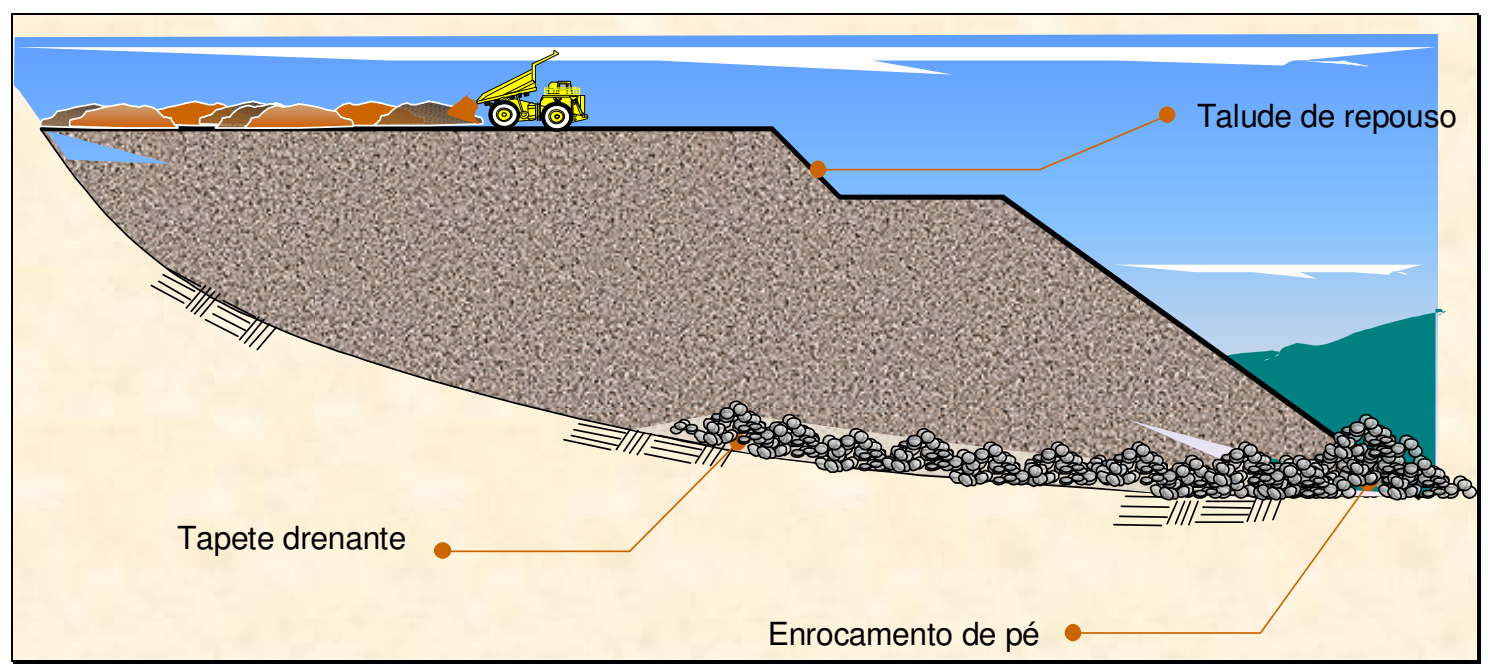

Figura 6 - Croqui sem escala da fase de lançamento do método ascendente Fonte - Apostila sobre formação de depósito de estéril e rejeito, Relatório interno Vale, 2000 


\subsubsection{Retaludamento de Bancadas}

Após a conclusão de cada bancada, deverá ser executado o retaludamento, motivo pelo qual se deve formar a pilha com bermas entre 10 e 12 metros, que consiste em quebrar a crista de cada bancada para suavizar o ângulo de repouso. Esta operação tem por objetivo aumentar a estabilidade da pilha através da compactação da superfície.

Em alguns casos, dependendo do resultado da análise da estabilidade, e do material que está sendo empilhado, pode-se lançar o estéril em ponta de aterro, e se executar o retaludamento para favorecer a compactação da superfície.

\subsubsection{Sistema de Drenagem}

Através do planejamento de longo prazo são definidos os planos de drenagem das minas, como objetivo de racionalizar a seqüência de lavra sem prejudicar a sua operação, bem como projetar obras civís para captar e conduzir a drenagem de forma adequada.

$\mathrm{Na}$ fase do planejamento e ao longo da lavra, deve-se manter o controle do nível de drenagem das bancadas para que se favoreça ao aspecto operacional e econômico, reduzindo os processos erosivos causados pelas águas de chuva e conseqüente carreamento de finos para áreas externas à lavra.

Deve-se observar sempre o sentido de caimento da drenagem superficial para minimizar as erosões.

Para cada pilha, é definido um sistema de drenagem com inclinação de $1 \%$, suficiente para evitar erosões e para impedir empoçamento da água. Para proteger a 
face do banco, evitando que a água desça pela crista, deve-se dotar a berma de um caimento de 3 a 5\% em direção ao pé da bancada superior. Poderá ser executada uma leira junto à crista (banqueta). Após a conclusão de cada bancada, é conveniente cobrir os taludes com uma fina camada de solo rico em compostos orgânicos, proveniente da limpeza da fundação, para facilitar seu plantio.

O processo de formação da pilha por via seca pelo método ascendente permite ainda o zoneamento interno dos materiais a serem dispostos, de forma a aproveitar ao máximo as características de resistência e permeabilidade de cada material.

Canaletas de drenagem com dissipadores de energia devem ser construídas no entorno da pilha em terreno natural. A água proveniente das bermas deverá ser conduzida para estas canaletas.

\subsubsection{Drenagem Interna}

Também chamada drenagem de fundo. É a drenagem executada com o objetivo de canalizar curso de água, nascentes. Normalmente é uma obra contratada. Para favorecer a drenagem em áreas que não possuem cursos d'água, deve-se forrar a base da pilha com material de granulometria maior para que funcione como tapete drenante.

\subsubsection{Drenagem Superficial}

Durante a evolução das pilhas, com o objetivo evitar as erosões, deverá ser dado o caimento adequado às praças, a partir de pontos determinados, com declividade de 1\%. Para evitar que a água caia pelas faces dos taludes. As bermas deverão ser construídas com caimento de $5 \%$ em direção ao pé da bancada superior. 
Após a conclusão das bancadas e implantação do sistema de drenagem, deverão ser executadas as descidas d'água com enrocamento para redução da velocidade da água que poderão criar as erosões. A garantia para a eficiência do sistema de drenagem superficial é a criação de canaletas nas praças que dirijam as águas para os pontos de descida.

Em sua fase final, deverá ser providenciado o plantio de gramíneas e de plantas nativas para recobrimento e maior proteção dos taludes e bermas.

\subsubsection{Drenagem Periférica}

A drenagem periférica tem como objetivo receber as águas das descidas d'água e lança-las na drenagem natural com o menor impacto possível. Prevê-se que desta forma, durante a evolução das pilhas, serão preparadas áreas preferenciais para descidas d'água e enrocamento no pé dos taludes. Será conveniente a construção do enrocamento com materiais de granulometria mais grosseira e resistente, de maneira que atuem como um muro de contenção estéril, evitando que a ação das águas cause erosões. A Figura 7 mostra os tipos de sistemas de drenagens. 


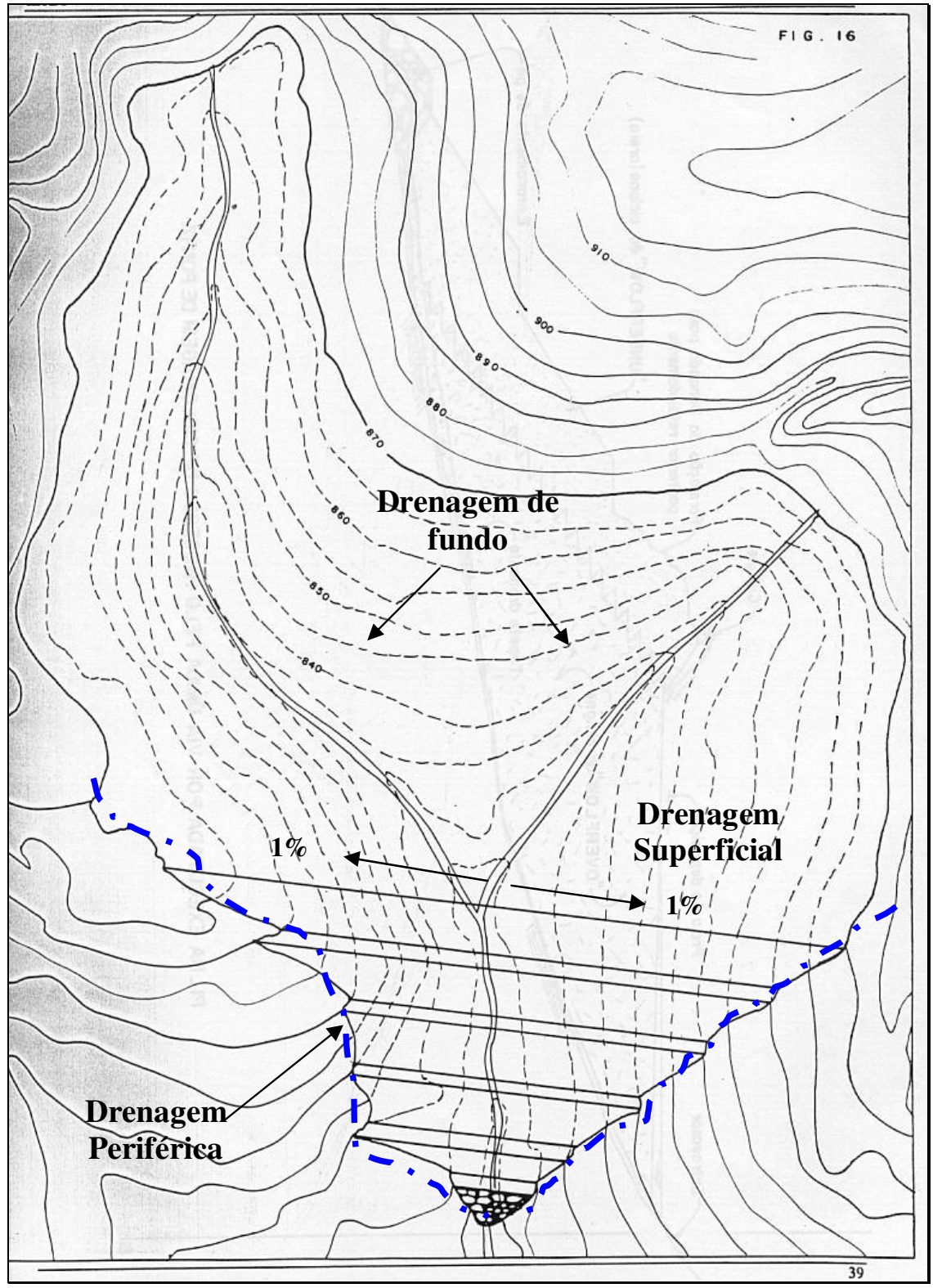

Figura 7 - Croqui sem escala dos sistemas de drenagens Fonte - Apostila sobre formação de depósito de estéril e rejeito, Relatório interno Vale, 2000 


\subsubsection{Planejamento de diques de contenção de finos}

Cabe ao sistema de drenagem prover condições favoráveis à retenção de finos dentro da mina, evitando assoreamento de barragens e possíveis transtornos à comunidade.

Porém, de posse do planejamento da lavra a longo prazo, deve-se levantar, através da localização das pilhas de estéril e do traçado da cava, os pontos que deverão ser dotados de sistema de contenção de finos.

Estes diques têm a função de promover a decantação (retenção das partículas sólidas desprendidas das pilhas) para que a água transborde limpa dos tanques. 


\section{METODOLOGIA DO TRABALHO}

A metodologia abordada tem como intuito possibilitar a diminuição considerável da área degradada da Flonaca (Floresta Nacional de Carajás), com redução dos impactos ambientais na região, além de conduzir a uma menor distância de transporte do estéril removido das áreas em lavra.

Através da leitura deste Capítulo, pode-se ter uma visão geral dos vários aspectos abordados na elaboração do Planejamento de Serra Sul, bem como das ferramentas computacionais utilizadas no desenvolvimento da mesma.

\subsection{DADOS E RECURSOS UTILIZADOS}

Para a elaboração da dissertação de mestrado a Diretoria de Planejamento e Desenvolvimento de Ferrosos da Vale (DIPF) disponibilizou os seguintes dados:

-Modelo de blocos tridimensional de Serra Sul;

-Teores de corte;

-Cava final operacionalizada;

-Modelo do NPV;

-Seqüenciamento de lavra atual da mina (geometrias e tabelas);

-Depósitos de estéril e estoques (geometrias e capacidade anual);

-Distâncias de transporte anual por área. 


\subsection{METODOLOGIA GERAL DO PLANEJAMENTO DE LAVRA}

A metodologia geral consiste no Planejamento de Lavra de Serra Sul a partir da definição do modelo econômico e da cava matemática, que permitirá o controle das restrições econômicas, geométricas, operacionais, e de qualidade, contando para isso com a utilização de recursos computacionais baseados em conceitos derivados das técnicas mais empregadas e respeitadas na atualidade.

A seguir serão apresentadas as principais etapas do trabalho:

- Criação dos modelos geológicos e geotécnicos;

- Definição da função benefício do empreendimento;

- Definição dos objetivos de produção da empresa, incluindo qualidade e restrições;

- Otimização da cava e seqüenciamento de lavra.

De forma geral, os objetivos estão mais bem relacionados através da Figura 8, a seguir. 


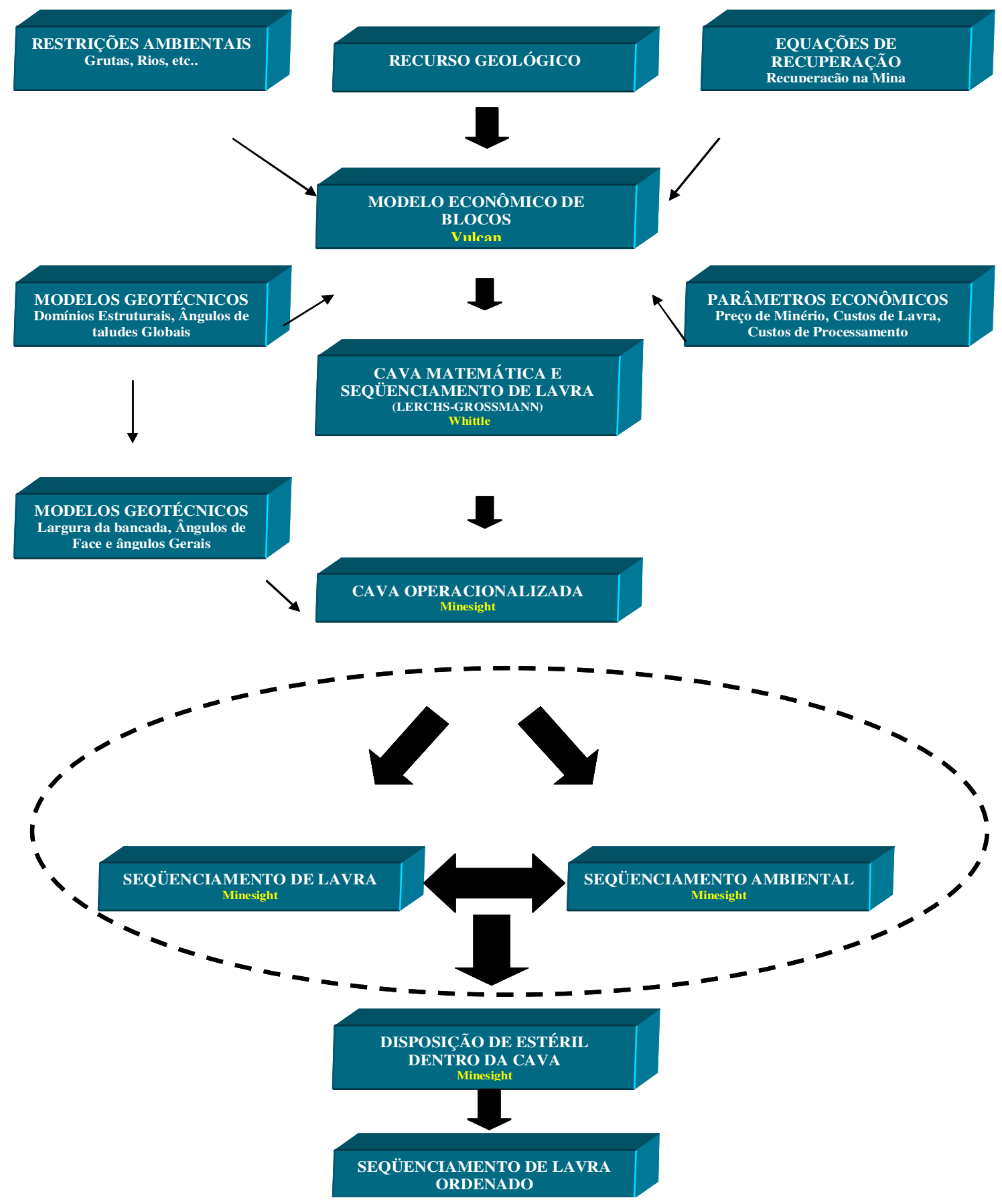

Figura 8 - Fluxograma da metodologia geral do planejamento de lavra Fonte - Carvalho e De Tomi, 2009

A metodologia geral do planejamento de lavra consiste nos seguintes passos:

- A partir do recurso geológico representado por um modelo de blocos tridimensional, foram considerados apenas os recursos medidos e indicados (posteriormente convertidos para reservas provadas e prováveis). Realizou-se 
uma preparação desse modelo de blocos que consistiu na atualização do modelo removendo-se tudo que já tinha sido lavrado e na incorporação ao modelo de atributos referentes aos tipos de minério e materiais para o cálculo do valor econômico de cada bloco em função de parâmetros econômicos, equações de recuperação de mina e processamento. Foram incorporados, também, parâmetros geotécnicos e as restrições ambientais para controlar as expansões das cavas.

- Uma vez preparado o modelo de blocos, o passo seguinte consistiu na otimização econômica e seqüenciamento de lavra de longo prazo, visando a definição da geometria final da cava ótima e dos períodos qüinqüenais de lavra da mina.

- Em seguida, as cavas matemáticas geradas no Whitlle, que definem a cava final ótima e as cavas dos períodos qüinqüenais de lavra foram exportados para o Minesight, onde foram operacionalizadas. Dessa forma a Cava final foi operacionalizada, porém, nessa primeira rodada do seqüenciamento automático, foi visto que o mesmo não atendia à premissa principal do estudo, que era exaurir de uma forma ordenada áreas da mina para a disposição de estéril, devido a isso todo o seqüenciamento de lavra foi revisado manualmente no aplicativo Minesight.

- Finalmente, como premissa para o seqüenciamento de lavra, adotou-se a estratégia de iniciar a lavra pela extremidade leste do corpo $\mathrm{D}$, e dar seguimento das operações de lavra em direção a oeste, de forma a criar condições para a colocação de estéril dentro da cava nos anos posteriores, ou seja, se propõe uma lavra no sentido leste-oeste, de forma ordenada.

- A partir da exaustão de parte da cava, o projeto da pilha de estéril começa a ser executado Tal projeto é bem simplificado, porque na região em cava o material estéril depositado ficará confinado entre as paredes da mina, sem risco de ruptura dos taludes. 


\subsection{METODOLOGIA ESPECÍFICA DO SEQÜENCIAMENTO DE LAVRA ORDENADO}

A metodologia específica do Seqüenciamento de Lavra ordenado consiste no ínicio da lavra pela extremidade do corpo, exaurindo a mina de forma a possibilitar a disposição de estéril dentro da cava, à medida que evolui a lavra nas outras regiões.

A seguir serão apresentadas as principais etapas do trabalho:

- Análise da Geologia Local;

- Análise da malha de sondagem;

- Estudo Geotécnico;

- Avaliação por área da cava;

- Seqüenciamento Ordenado;

- Disposição de estéril dentro da cava.

Podemos verificar com mais detalhes a metodologia específica na Figura 9 a seguir.

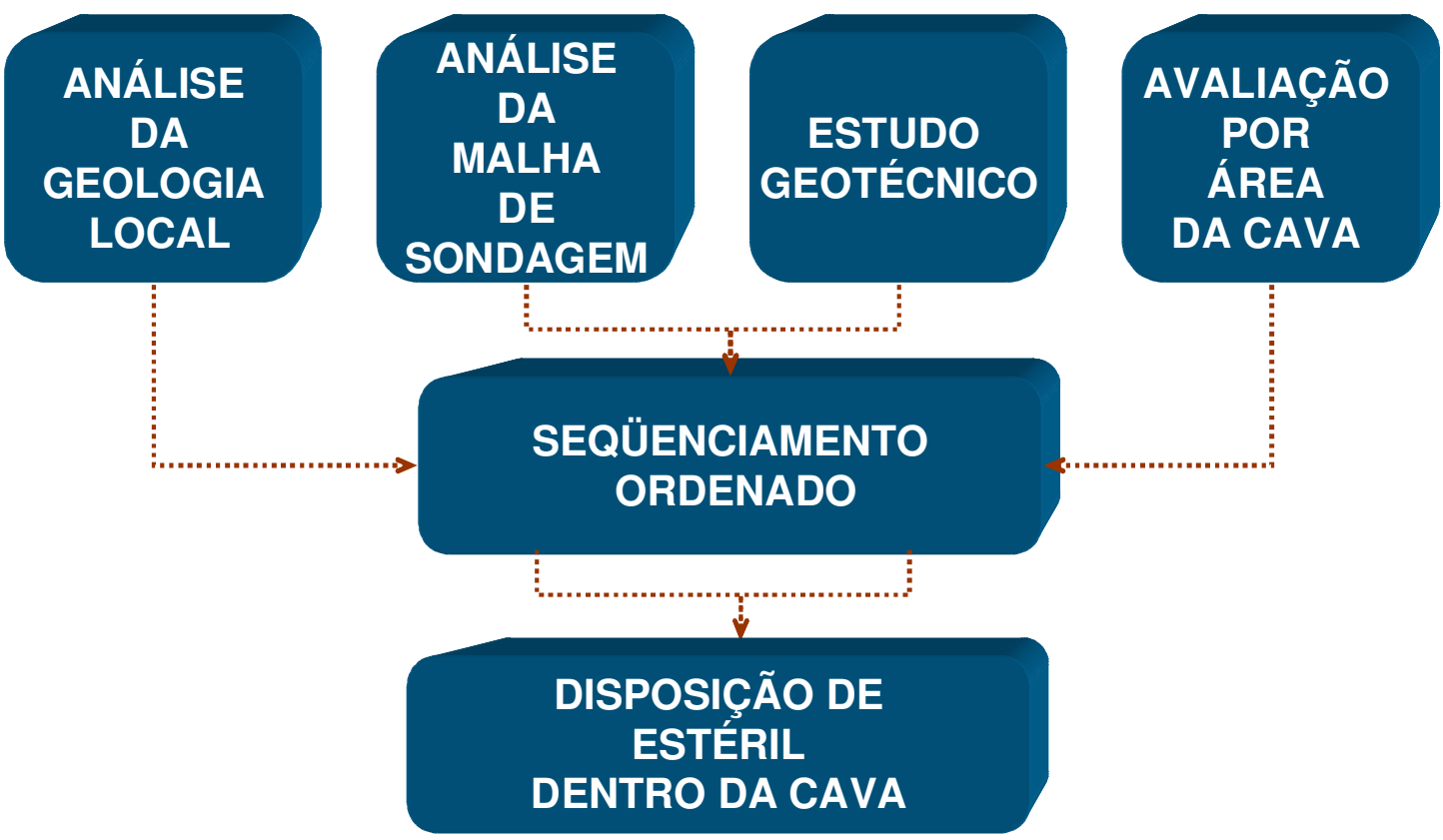

Figura 9 - Fluxograma da metodologia específica do seqüenciamento de lavra ordenado Fonte - Carvalho e De Tomi, 2009 
A metodologia específica do seqüenciamento ordenado consiste nos seguintes passos:

- Análise da Geologia Local para verificar o mergulho do corpo de minério, pois, corpos extensos e rasos viabilizam positivamente essa metodologia;

- Análise da malha de sondagem da região, verificando se a área de interesse do ínicio da lavra está bem fechada, ou se existe um período de tempo para fechar essa malha até o ínicio das operações da mina, viabilizando dessa forma uma maior segurança na lavra do minério da região e também na disposição de estéril futura, minimizando o risco de dispor estéril em áreas potenciais de minério;

- Estudo Geotécnico das áreas onde será efetuada a disposição do estéril lavrado. Esse estudo garante a segurança dos bancos que ficarão na encosta, além dos bancos em cava. Não é o caso desse estudo, pois, todo o estéril nessa revisão foi considerado confinado na cava;

- Avaliação por área da cava para o conhecimento da qualidade e da relação estéril minério por região da mina. Em minas com o tipo de minério homogêneo há uma segurança maior na adaptação da metodologia, pois não prejudica a estacionarização da qualidade nos anos correntes;

- Com as análises descritas acima realizadas, temos o embasamento necessário para realizar o seqüenciamento de lavra ordenado, iniciando a lavra pela extremidade do corpo;

- Após parte da cava exaurida, é possível a disposição do estéril dentro da mina de forma ordenada, enquanto a lavra continua normalmente nas outras regiões da cava. 


\section{ESTUDO DE CASO}

\subsection{CARACTERIZAÇÃO DAS MINAS DE FERRO DE CARAJÁS NO SISTEMA NORTE}

O Projeto Ferro Carajás, um sistema integrado Mina-Ferrovia-Porto, é formado pelas minas, localizadas na Floresta Nacional de Carajás, município de Parauapebas a $550 \mathrm{Km}$ a sudoeste de Belém, no estado do Pará, pela estrada de Ferro Carajás, com $892 \mathrm{Km}$ de extensão e pelo terminal Marítimo de Ponta da Madeira, localizado a $9 \mathrm{Km}$ a sudoeste de São Luís do Maranhão. Produz diversos produtos destinados à indústria siderúrgica. A Figura 10 mostra com mais detalhes a localização do sistema integrado Mina-Ferrovia-Porto.

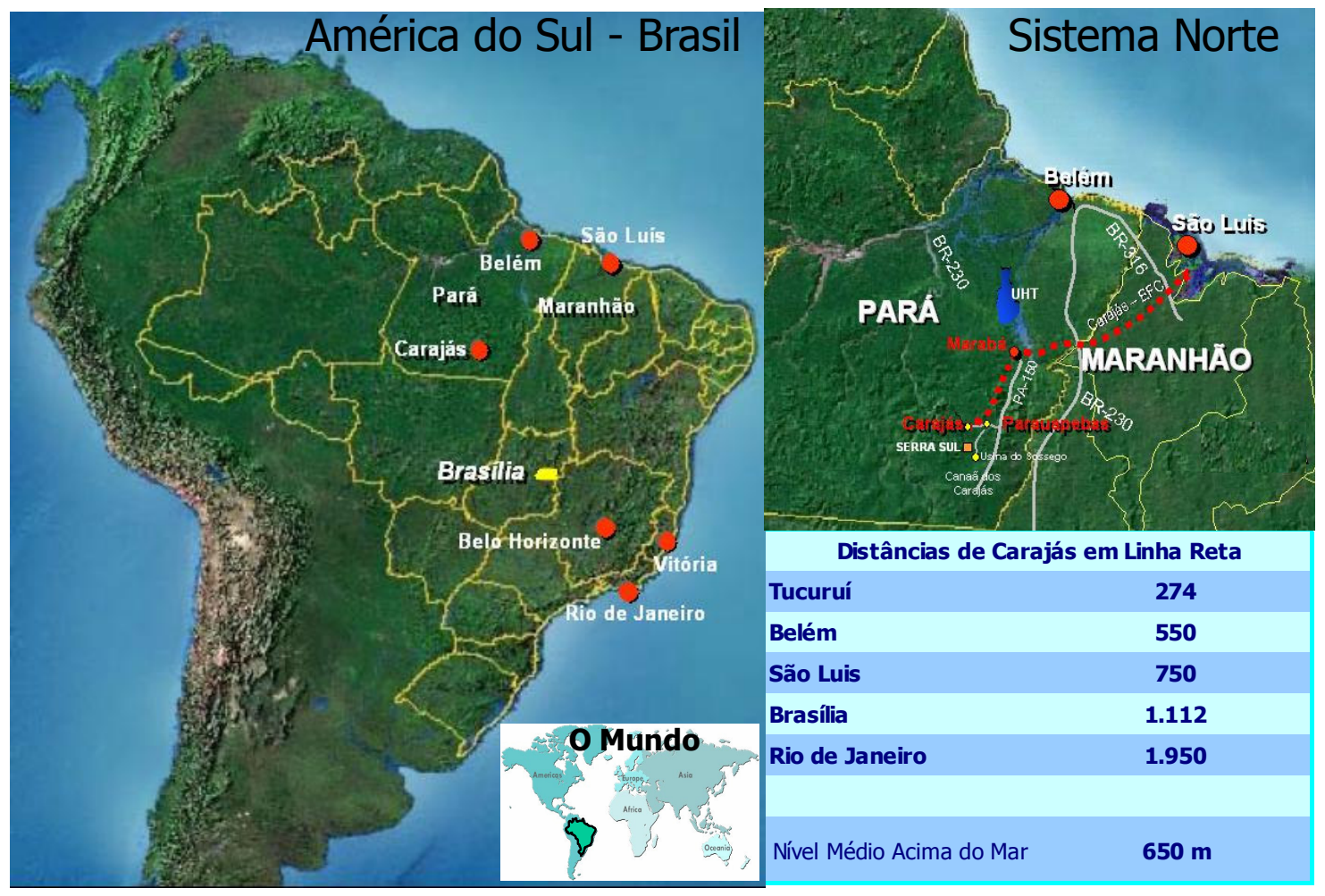

Figura 10 - Croqui sem escala da localização do projeto ferro Carajás Fonte - Carajás Update, Relatório Interno Vale, 2006 
Além das minas de minério de ferro, a província mineral possui ainda depósitos de minério de manganês, cobre e níquel, demonstrando assim a grande diversidade mineral desta região. A Figura 11 apresenta a província mineral, na região da Floresta Nacional de Carajás (Flonaca).

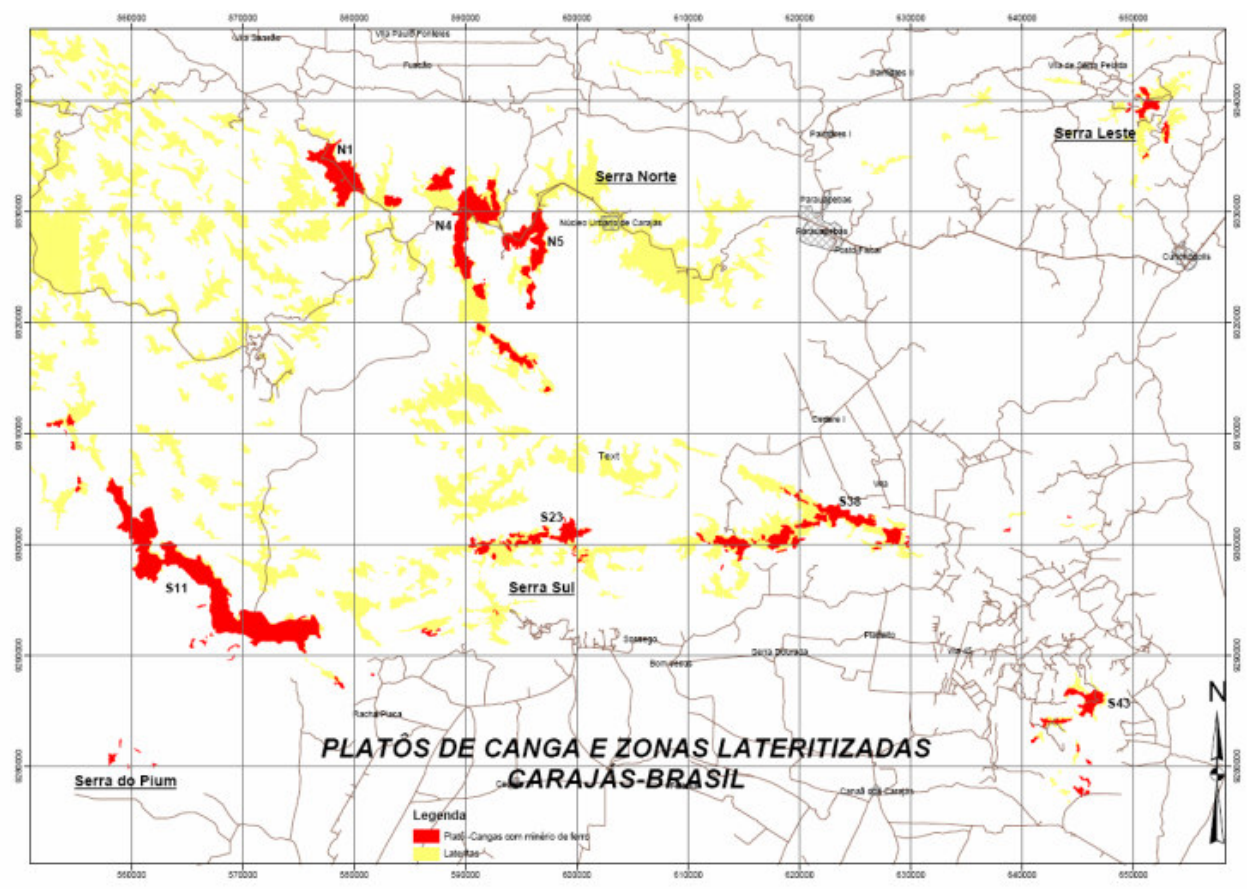

Figura 11 - Croqui sem escala do mapa de localização dos principais platôs da província mineral em Carajás

Fonte - Relatório de Avaliação de Recursos de Serra Sul, Relatório interno Vale, Set/2008

Todos os planos de lavra são elaborados de forma integrada, ou seja, consideram as várias minas ora em operação (N4E, N4W, N5W e N5E), sendo lavradas simultaneamente, objetivando produzir uma mistura de materiais com a menor variação possível a longo prazo, fato desejado para manutenção dos atuais clientes.

A lavra do minério de ferro iniciou-se pelo corpo de $N 4 E$, em função da sua localização e qualidade do minério contido, com baixos teores de ganga. A Figura 12 apresenta a localização das minas de ferro ora em lavra no sistema norte.

O método de lavra utilizado é a céu aberto, com bancadas de 15 metros de altura e operações de perfuração, detonação, carregamento e transporte do minério. A operação de carregamento é efetuada com escavadeiras a cabo e hidráulicas e pás mecânicas. O transporte até as unidades de britagem é efetuado através de caminhões fora de estrada. 
As minas de Carajás apresentadas na Figura 12 são dotadas de 3 equipamentos de britagem primária semi-móveis (BSM), localizados nas minas $\mathrm{N} 4 \mathrm{E}, \mathrm{N} 4 \mathrm{~W}-\mathrm{N}$ e $\mathrm{N}-5$, que tem a finalidade de reduzir a distância de transporte do minério lavrado até a usina de beneficiamento, aumentando a produtividade e reduzindo os custos do sistema, além de,uma instalação fixa de britagem primária.

O alto teor de ferro in natura da hematita de Carajás é responsável por considerável redução nos custos de beneficiamento do minério, que não necessita de concentração. Esse processo consiste basicamente de operações de britagem, classificação, desaguamento, moagem e filtragem. Os produtos obtidos são o sinter feed, o granulado, o pellet feed e os Finos para Redução Direta. Esta usina de beneficiamento possui capacidade de produção anual de $100 \mathrm{Mt}$ de produtos. Em Carajás, depois de beneficiados, os produtos são empilhados nos pátios de estocagem e posteriormente expedidos para o Terminal Marítimo de Ponta da Madeira, nos vagões da Estrada de Ferro Carajás.

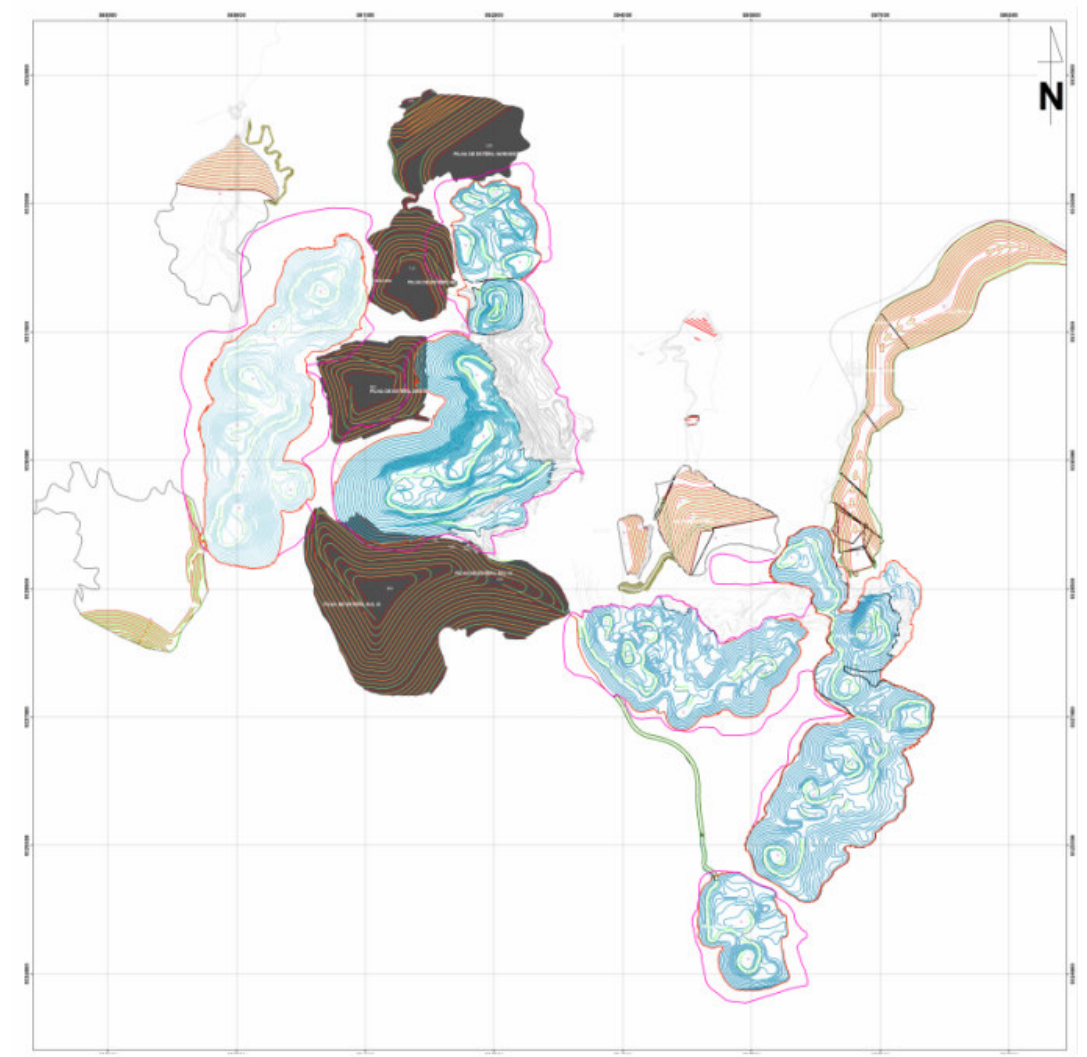

Figura 12 - Croqui sem escala das minas de ferro em lavra atualmente no sistema norte Fonte - Relatório programa 130 Mta, Relatório interno Vale, 2007 
Chegando ao Porto, o minério é descarregado através de dois viradores de vagões com capacidade individual de $8.000 \mathrm{t} / \mathrm{h}$ e estocado em pátios com capacidade para 3.9 Mt de produtos.

\section{2 LOCALIZAÇÃO SERRA SUL}

A jazida de Serra Sul, objeto desse estudo, está situada na Província Mineral de Carajás em uma área denominada S11. A jazida de $S 11$ faz parte do grupamento mineiro de Serra Sul definido pelo Processo DNPM 74.508/74.

A área $S 11$ foi dividida, para efeito de pesquisa mineral, em quatro corpos: $A, B, C$ e D. Para efeito de lavra, serão considerados somente os corpos C e D de S11.

Os corpos C e D estão definidos pelas coordenadas UTM 9.290.000N, $566.000 \mathrm{E}$ 9.297.000N e 578.000E. As cavas geradas, compreendendo os Corpos C e D, englobam os recursos medidos e indicados, podendo ser acrescidas, no futuro, dependendo dos resultados de campanha de sondagem complementar nas regiões onde o status do recurso é inferido.

A área $S 11$ pode ser acessada por estrada não pavimentada, com largura aproximada de $10 \mathrm{~m}$ e também a partir de acessos em fazendas localizadas nas proximidades dos corpos de minério. Existe, no local, um heliporto próximo ao acampamento de sondagem. Na Figura 13 temos a subdivisão de S11. 


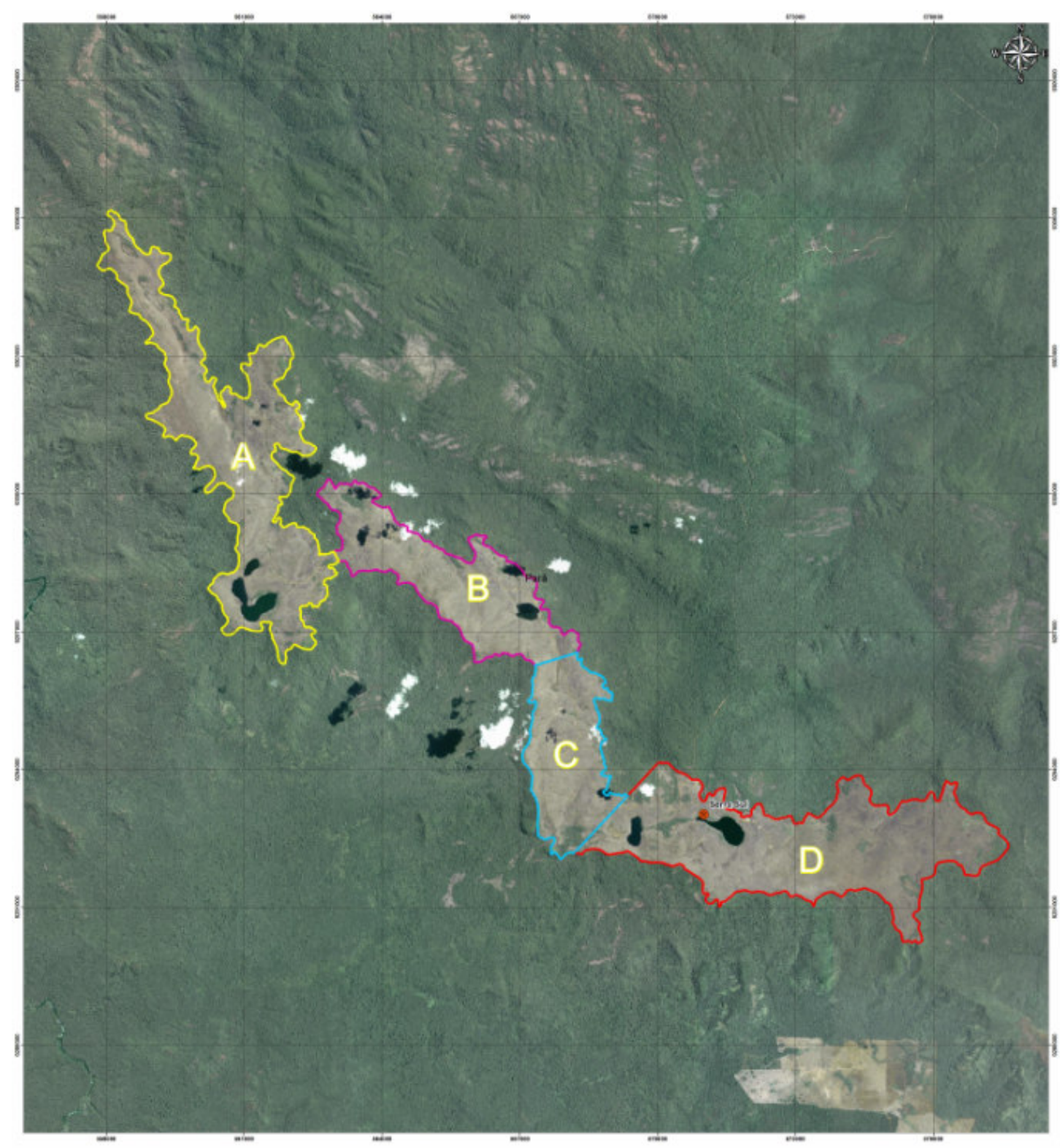

Figura 13 - Croqui sem escala da imagem lkonos de Serra Sul mostrando o platô do alvo S11 e a subdivisão dos corpos.

Fonte - Relatório de Avaliação de Recursos de Serra Sul, Relatório interno Vale, Set/2008

\subsection{GEOLOGIA DE SERRA SUL}

Segundo o relatório da Diretoria de Desenvolvimento de Projetos Minerais (DIPM), relativo à campanha de sondagem realizada de 2005 a 2007, referente à geologia da jazida de Minério de Ferro de Serra Sul (denominada de S11), a referida jazida está 
assentada num trend SE-NW com $28 \mathrm{~km}$ de comprimento por $1 \mathrm{~km}$ de largura e profundidade conhecida de 600 metros. Com o conhecimento inicial destas características da geologia da região, um corpo de minério extenso e raso, deu-se ínicio ao estudo em questão.

O conjunto das Serras Sul dos Carajás abriga o maior jazimento do Projeto Serra Sul, o platô S11. Segundo dados do projeto RADAMBRASIL (1974), a região sul do Pará está no contexto de duas grandes unidades morfoestruturais e morfoclimáticas por conseqüência: planalto dissecado do sul do Pará e depressão periférica do sul do Pará.

A tipologia usada no mapeamento das Minas de Serra Sul obedeceu às nomenclaturas e definições usadas pelas Minas de Ferro do Sistema Norte, ora em operação. Na classe dos minérios têm-se os tipos: CM [Canga de Minério], HM [Hematita Mole], HDL [Hematita Dura Limonitizada], HLL [Hematita Laminada Limonitizada], HD [Hematita Dura], JP [Jaspelito], JPCb [Jaspelito Carbonático], e na classe dos estéreis os tipos: CQ [Canga Química], MS [Máfica Sã], MD [Máfica Decomposta]. As Figuras 14 e 15 mostram os tipos de materiais encontrados na Jazida de Serra Sul.
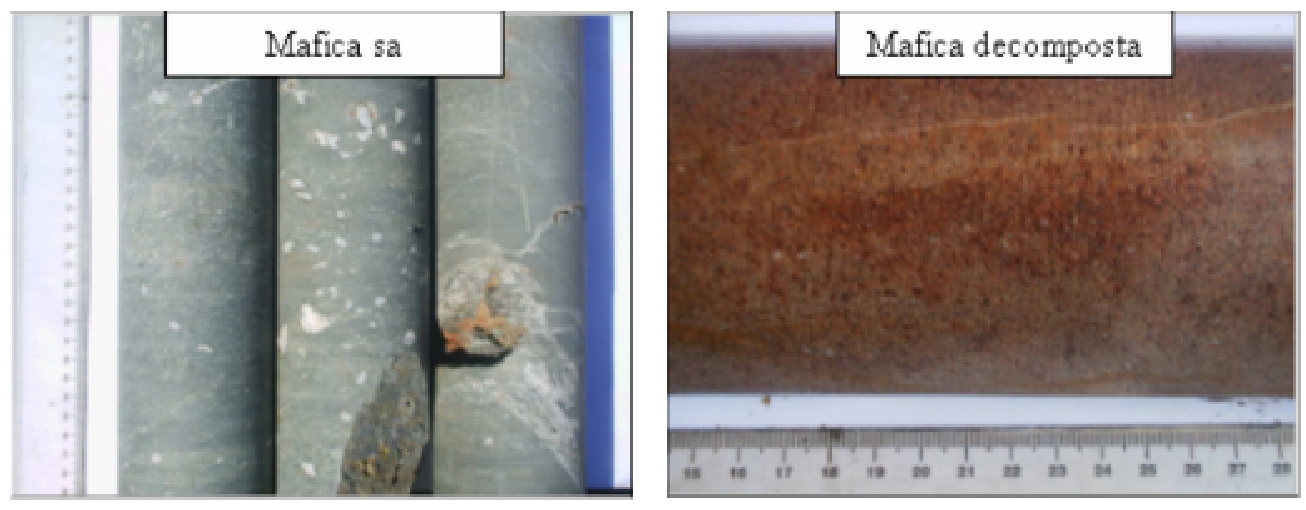

Figura 14 - Máficas encontradas na jazida de Serra Sul Fonte - Relatório de Avaliação de Recursos de Serra Sul, Relatório interno Vale, Set/2008 

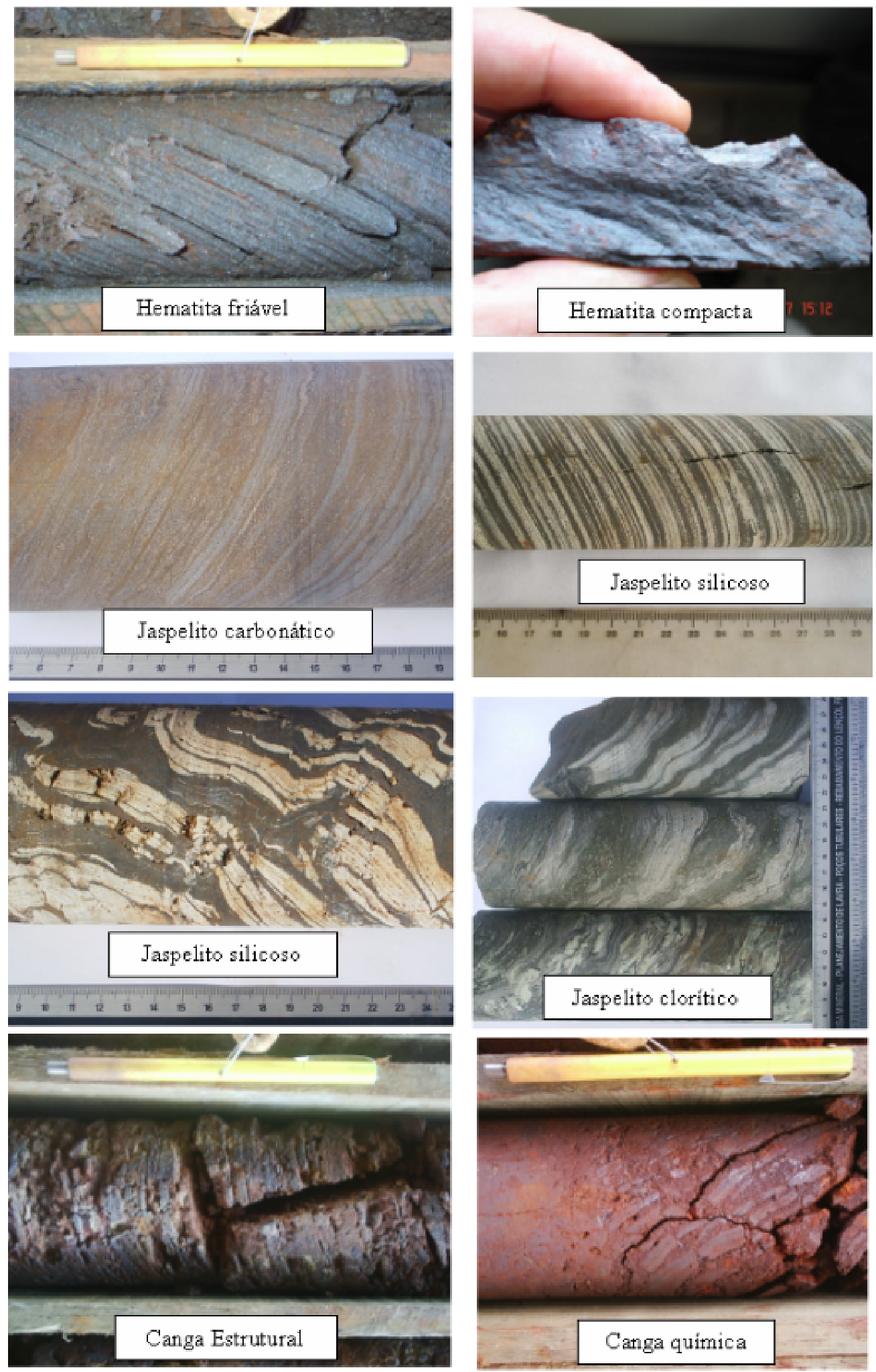

Figura 15 - Tipos de rochas ricas em ferro encontradas na jazida de Serra Sul Fonte - Relatório de Avaliação de Recursos de Serra Sul, Relatório interno Vale, Set/2008 
Dentro do procedimento de determinação de cava final, o principal fator geométrico que restringe a cava, ao lado do limite de concessão de lavra, é o ângulo de talude final.

Para a avaliação dos possíveis ângulos de talude da cava, tanto final, quanto operacional, deverão ser realizados estudos geomecânicos detalhados dos diferentes tipos de materiais existentes. Tais estudos compreendem, entre outros, a determinação das principais estruturas geológicas, conhecimento hidrogeológico da região e ensaios geotécnicos. Partindo destas informações, o modelo poderá ser criado, indicando os ângulos de talude médios, conforme as características geotécnicas de cada setor da mina.

A princípio, os ângulos de estabilidade são medidos em relação à vertical, considerado para determinação da cava preliminar concebida para esta mina será correlacionado ao tipo de material (minério ou estéril). Adotou-se serem os mesmos utilizados em N4E, mina existente e ora em operação no Sistema Norte, em Carajás, conforme Tabela 1.

Tabela 1 - Parâmetros geotécnicos com base no tipo de material Fonte - Relatório Serra Sul Fel 3 - Relatório interno Vale, Mar/2008

\begin{tabular}{lccc}
\hline Material & $\begin{array}{c}\text { Ângulo geral } \\
\text { (graus) }\end{array}$ & $\begin{array}{c}\text { Ángulo de } \\
\text { face } \\
\text { (graus) }\end{array}$ & $\begin{array}{c}\text { Largura de bermas } \\
\text { (m) }\end{array}$ \\
\hline Hematita Mole & 40 & 62 & 10.0 \\
Hematita Dura & 50 & 70 & 7.2 \\
Canga de Minério & 40 & 62 & 10.0 \\
Canga Química & 40 & 62 & 10.0 \\
Máfica Sã & 50 & 70 & 7.2 \\
Máfica Decomposta & 30 & 40 & 8.1 \\
Jaspilito & 50 & 70 & 7.2 \\
Demais Materiais & 40 & 62 & 10.0 \\
\hline
\end{tabular}




\subsection{ESTUDO DE CAVA FINAL}

Esse primeiro estudo de cava final de Serra Sul datado de julho/2007 foi desenvolvido em conjunto com a Diretoria de Desenvolvimento de Projetos Minerais (DIPM) e a Diretoria de Planejamento e Desenvolvimento de Ferrosos (DIPF) da Vale.

A metodologia utilizada para determinação das cavas otimizadas foi a maximização de uma função benefício econômico utilizando-se o algoritmo de Lerchs-Grossmann.

Foram considerados apenas dois produtos, em conformidade com a rota principal de processo, considerada no estudo de viabilidade: Sinter Feed mais a britagem da fração granulada, e o outro produto é o Pellet Feed. O modelo geotécnico usado foi baseado no modelo litológico, ou seja, foi associado um ângulo de talude para cada litologia. A Tabela 2 mostra a descrição dos domínios geológicos e ângulos de taludes.

Tabela 2 - Descrição dos domínios geológicos e ângulos de taludes Fonte - Relatório Serra Sul Fel 3 - Relatório interno Vale, Mar/2008

\begin{tabular}{|c|c|c|c|c|}
\hline LITOLOGIA & ROCKTYPE & Tipo de minério & $\begin{array}{c}\text { ROCKTYPE PARA } \\
\text { KRIGAGEM }\end{array}$ & Ângulo Talude \\
\hline $\mathrm{CM}$ & 1 & Canga de minério & \multirow{3}{*}{ 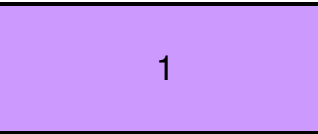 } & \multirow{3}{*}{30} \\
\hline$\overline{F F L}$ & 2 & Canga de minério & & \\
\hline HLL & 3 & Canga de minério & & \\
\hline $\mathrm{HM}$ & 4 & hematita mole & 4 & 40 \\
\hline $\mathrm{HD}$ & 5 & hematita dura & 5 & 55 \\
\hline FFC & 6 & hematita mole & \multirow{3}{*}{4} & \multirow{3}{*}{40} \\
\hline HCT & 7 & hematita mole & & \\
\hline MBT & 8 & hematita mole & & \\
\hline $\mathrm{JP}$ & 9 & Jaspilito & 9 & 55 \\
\hline $\mathrm{CQ}$ & 10 & Canga Química & 10 & \\
\hline $\mathrm{MD}$ & 11 & Máfica Decomposta & 11 & 30 \\
\hline MS & 12 & Máfica Sã & 12 & 55 \\
\hline $\mathrm{DB}$ & 15 & Diabasica & 15 & 30 \\
\hline QZ & 18 & Quartzito & 18 & 30 \\
\hline
\end{tabular}

Para a definição da cava matemática, foram considerados apenas os recursos medidos e indicados (posteriormente convertidos para reservas provadas e 
prováveis), conforme metodologia usada nas auditorias de reservas, na verdade, esta metodologia é a indicada pela SEC - da bolsa de NY-, onde a Vale tem listadas as suas ações, mas ela não difere muito da prevista pelo código JORC, da Austrália.

São apresentados, a seguir, os parâmetros e restrições utilizados para definição e cálculo da função benefício, utilizada na determinação das cavas otimizadas:

- As reservas são obtidas após a aplicação das restrições geoquímicas, geomecânicas, de processo, ambientais, de mercado e econômicas (custos de investimento e operacionais), etc;

- Para determinação dos blocos de minério adotou-se a seguinte restrição química de sílica (SiO2) menor do que 3.50\%;

- Para determinação do minério considerou-se apenas os recursos medidos e indicados;

- A princípio, o ângulo de estabilidade considerado para determinação da cava preliminar concebida para esta mina será correlacionado ao tipo de material (minério ou estéril). Adotou-se serem os mesmos utilizados em N4E.

Os recursos naturais reconhecidos através dos trabalhos de exploração constituem um banco de dados geológicos. A partir desses dados, um modelo de blocos é montado. Cada centróide de bloco contém as próprias informações como teores, faixa granulométrica e posição geográfica.

Para a valorização de cada bloco, foram definidos atributos segundo uma função benefício. Estes atributos permitem calcular a rentabilidade de cada bloco em função dos custos e receitas associados. A Figura 16 mostra os parâmetros associados à função benefício.

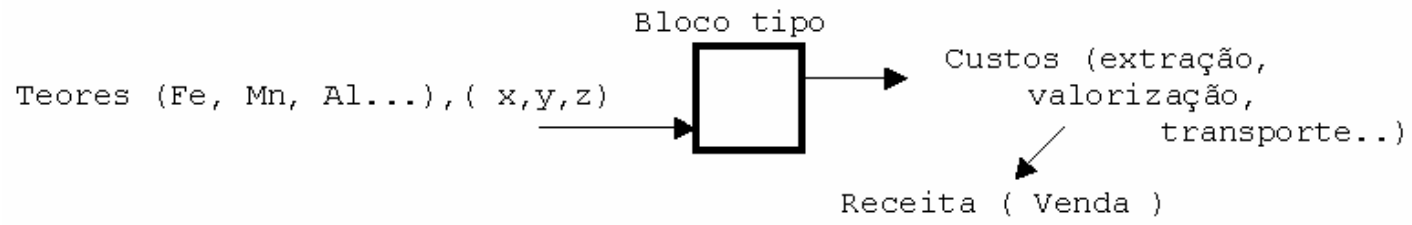

Figura 16 - Diagrama ilustrativo da função benefício Fonte - Relatório Serra Sul Fel 3 - Relatório interno Vale, Mar/2008 
Foram considerados como atributos:

- $\quad$ Custo de perfuração;

- $\quad$ Custo de detonação;

- $\quad$ Custo de carregamento;

- Custo rateio;

- $\quad$ Custo de transporte variável;

- $\quad$ Custo de transporte fixo;

- $\quad$ Custo de usina ferrovia;

- $\quad$ Custo de Porto;

- Impostos;

- $\quad$ Custos de investimentos correntes;

- Provisão para Fechamento de mina.

A formulação básica para um bloco contendo minério e estéril será:

VEB $=P^{*} V^{*} M^{*} R-\left(\left(C F L^{*} V M+C F B^{*} V M+C F E^{*} V E\right)-\left(C M P^{*} V P\right)-\left(C V M^{*} V M\right)-\right.$ $(C V E * V E))$

Onde: VEB é o valor econômico do bloco;

PV é o valor de venda do produto por unidade de peso $(\$ / t)$;

VM é o número de unidades de peso de minério contido no bloco (t);

$\mathrm{R}$ é a recuperação no processo (\%)

CFL são os custos fixos da lavra de minério por unidade de peso $(\$ / t)$;

CFB são os custos fixos do beneficiamento de minério por unidade de peso $(\$ / t)$;

CFE são os custos fixos da lavra de estéril por unidade de peso $(\$ / t)$;

CMP são os custos de movimentação entre o beneficiamento e faturamento do produto $(\$ / t)$;

CVM são os custos variáveis de lavra de minério por unidade de peso $(\$ / t)$;

CVE são os custos variáveis de lavra de estéril por unidade de peso (\$/t);

VE é o número de unidades de peso de estéril contido no bloco (t).

A função benefício foi desenvolvida com o objetivo de simular os custos de todas etapas do processo da lavra até o embarque do produto no porto e a obtenção da receita da venda.

A estimativa do custo a atribuir a cada bloco tem a seguinte rotina: 
- Estabelecer a condição do bloco (minério/estéril), em função da litologia e do teor de corte;

- Estabelecer os custos de perfuração e desmonte em função do material.

- Associar o custo de carregamento;

- Localizar o bloco e calcular a distância necessária de transporte do bloco (minério / estéril), até o destino final. Cada bloco tem o custo de transporte diferenciado em função da sua localização no espaço;

- Associar o custo de rateio;

- Associar os custo de Usina, Ferrovia e Porto;

- Associar o custo de investimento corrente, parcela para fazer frente aos investimentos destinados à manutenção do negócio, tais como reposição de frotas de equipamentos, investimentos para rebaixamento do lençol freático das minas, construção e ampliação de pilhas de estéril, etc referente às fases de mina, usina, ferrovia e porto, que foi acrescido no custo unitário para os respectivos processos. - Associar os custo de fechamento de mina (provisão);

-A receita bruta do bloco foi calculada em função da partição granulométrica do bloco e dos preços de venda em unidade metálica de cada um dos produtos e sua respectiva recuperação em massa.

As determinações da cava final e cava ótima foram realizadas através dos softwares Vulcan e Whittle compreendendo apenas os blocos dos recursos medidos e indicados, além de todos os parâmetros e restrições já mencionados.

Procedeu-se à criação e manipulação de variáveis através de scripts de matemática computacional para determinar o benefício de cada bloco, levando em consideração os parâmetros e restrições pertinentes. 
Posteriormente, considerando este benefício em conjunto com as restrições geomecânicas determinou-se a cava final utilizando-se do algoritmo de Lerchs \& Grossmann3D. A Figura 17 mostra a cava operacionalizada de Serra Sul.

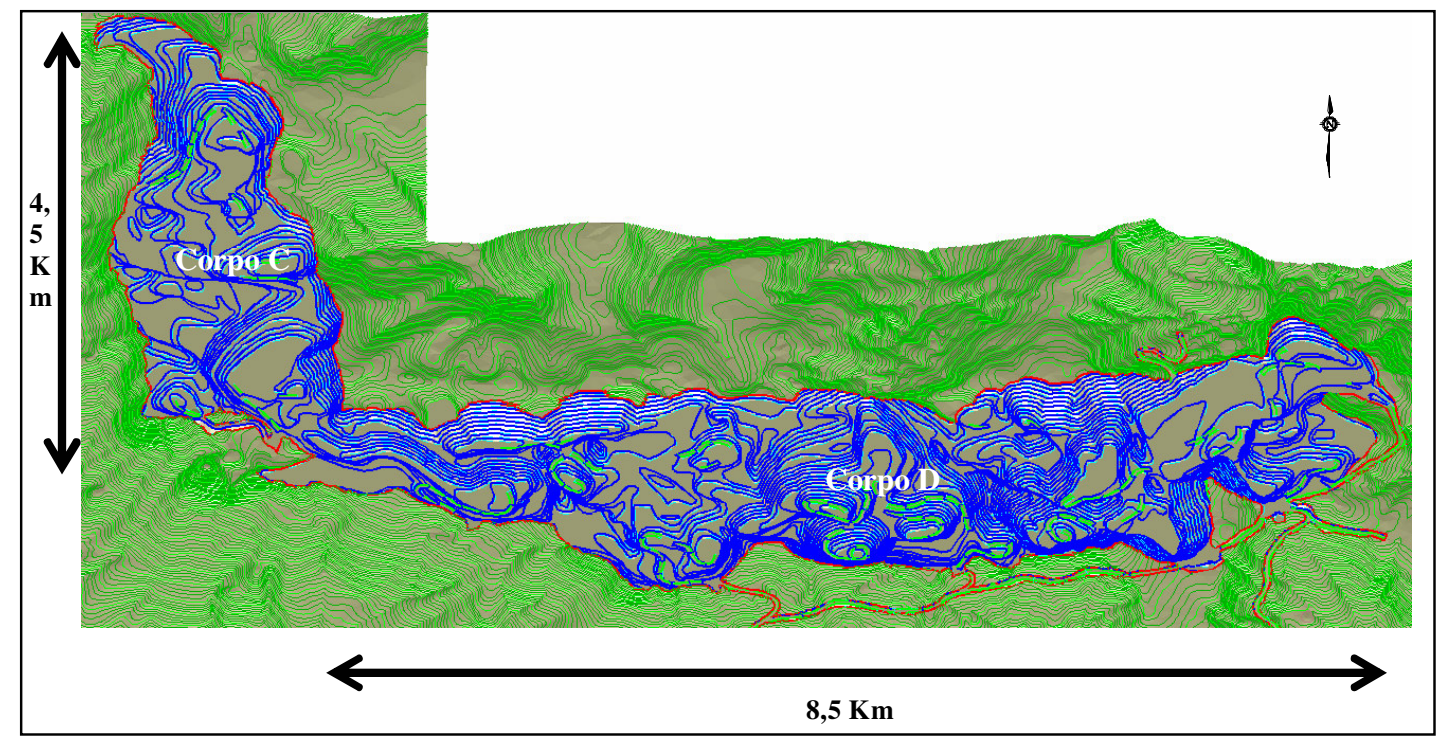

Figura 17 - Croqui sem escala da cava operacionalizada de Serra Sul Fonte - Relatório Serra Sul Fel 3 - Relatório interno Vale, Mar/2008

\section{5 SEQÜENCIAMENTO DE LAVRA}

\subsubsection{Seqüenciamento Matemático}

Buscou-se, neste trabalho, a definição de cavas matemáticas o mais operacionais possível, visando, desta forma, minimizar as diferenças de movimentação de estéril entre as cavas matemáticas e as operacionalizadas.

O plano de mina é pouco operacional, com frentes de lavra bastante espalhadas, devido à pequena escala e à grande área disponível ao longo da Serra, com minério disperso em pequenas porções, aflorando ou pouco profundo. Esta situação exige muito deslocamento dos equipamentos de carga, diminuindo a produtividade dos mesmos. 
Primeiramente, estes blocos tratados no Vulcan foram, posteriormente, exportados para o Whittle. Neste, através da variação do "Fator de Preço", obteve-se uma série de cavas aninhadas, utilizadas nos "Avanços Operacionais", para determinação do seqüenciamento anual requerido, através da utilização de algoritmos para maximização do Valor Presente Líquido.

As premissas consideradas para lavra foram:

- Posicionamento de 03 Britadores Primários Semi-Móveis próximos ao Corpo D;

- 03 pilhas para Disposição de Estéril;

- Produção base úmida da Planta de 100 milhões de toneladas por ano;

- Recuperação média da Planta de 92\%.

As Figuras 18 e 19 apresentam o seqüenciamento matemático dos anos 01 e 02.

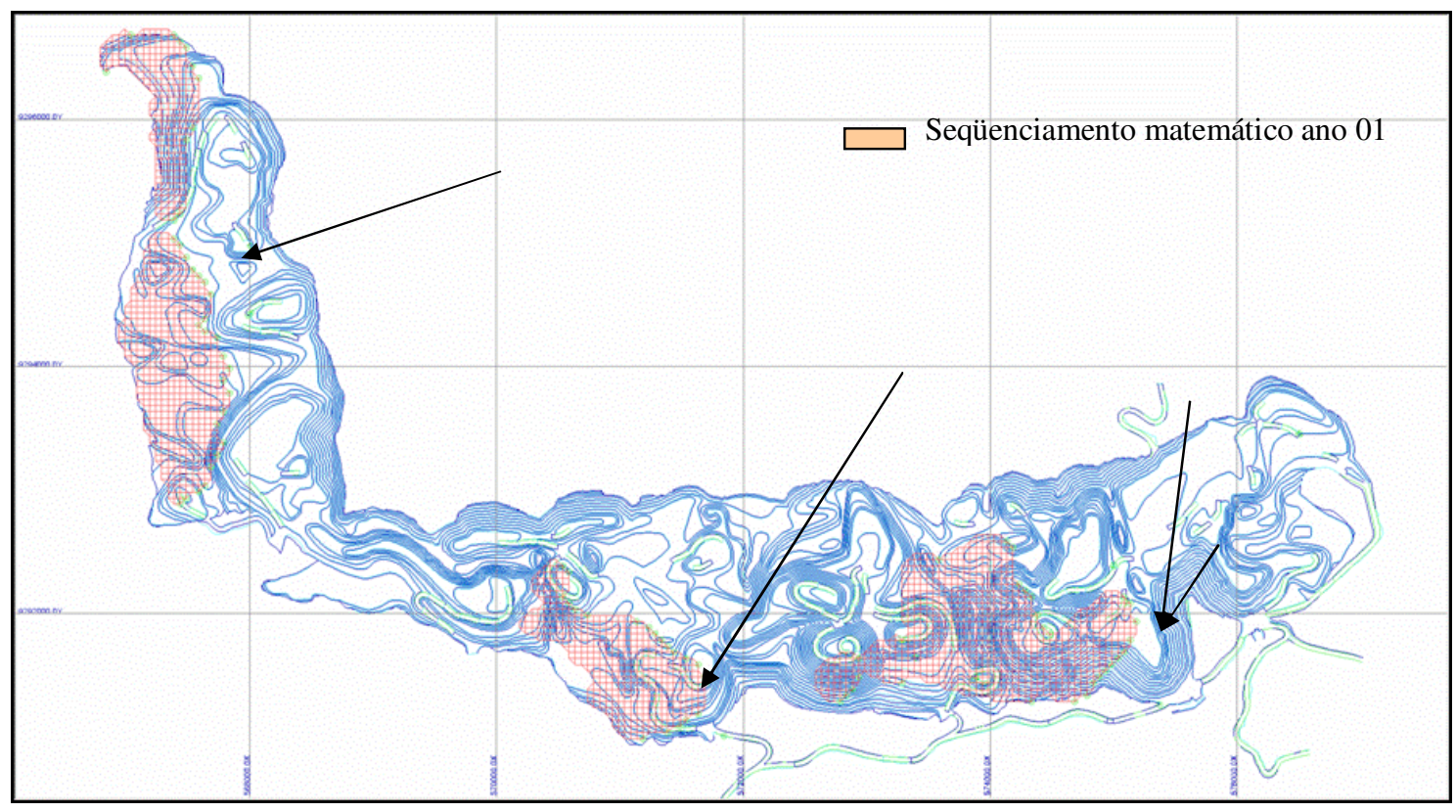

Figura 18 - Croqui sem escala do seqüenciamento matemático ano 01 Fonte - Carvalho e De Tomi, 2009 


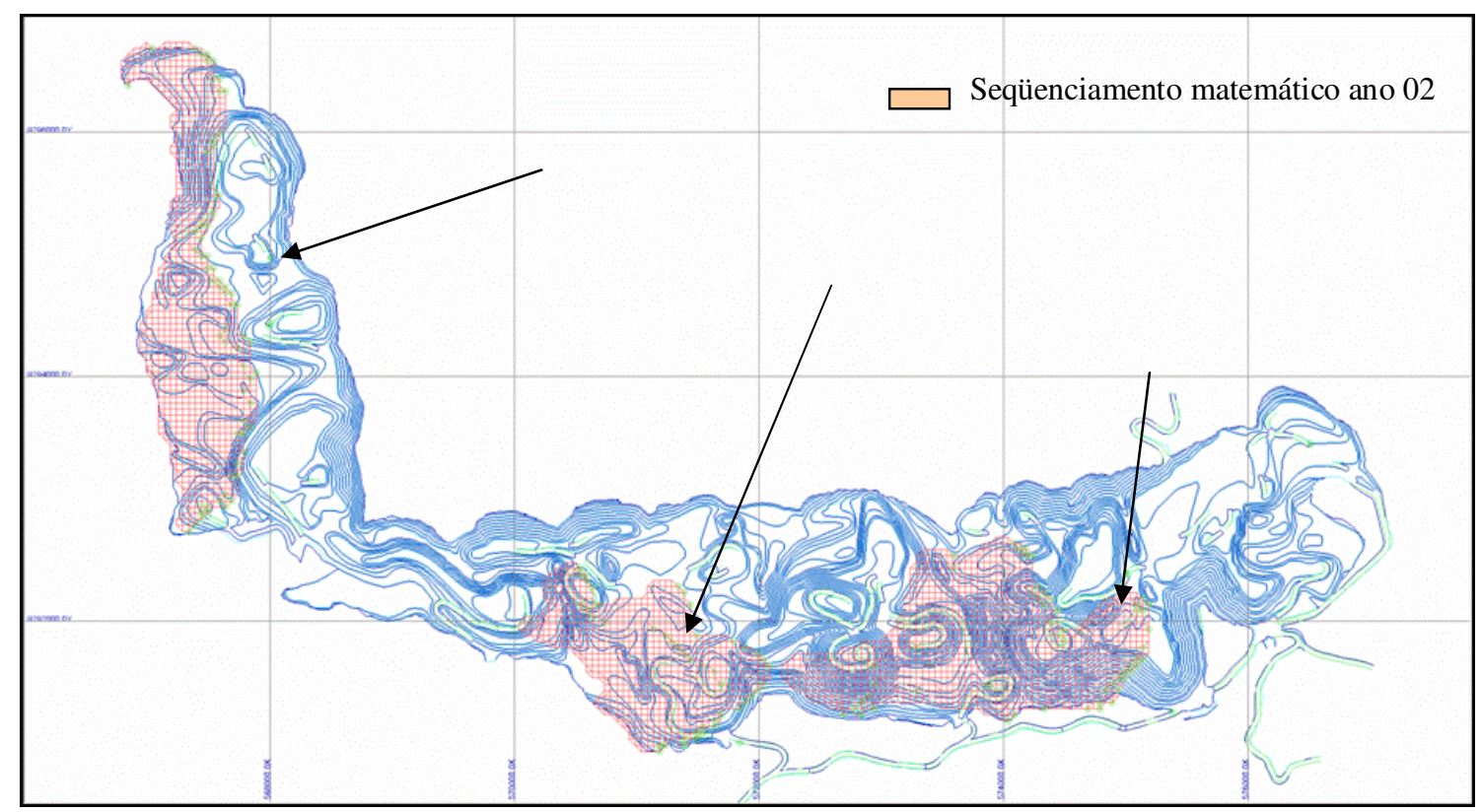

Figura 19 - Croqui sem escal do seqüenciamento matemático ano 02 Fonte - Carvalho e De Tomi, 2009

É importante ressaltar que o seqüenciamento matemático levou em conta a maximização do Valor Presente Líquido e com isso não houve a estacionarização das variáveis no decorrer dos anos, principalmente da sílica, como pode ser visto na Figura 20.

O alto teor de ferro in natura do minério do sistema norte, faz com que haja um diferencial no sistema que é o pagamento de um prêmio pelos produtos vendidos aos clientes e com isso é de extrema importância a estacionarização dos teores nos produtos ao longo dos anos para que esse prêmio continue, podendo ser cobrado dos clientes. 


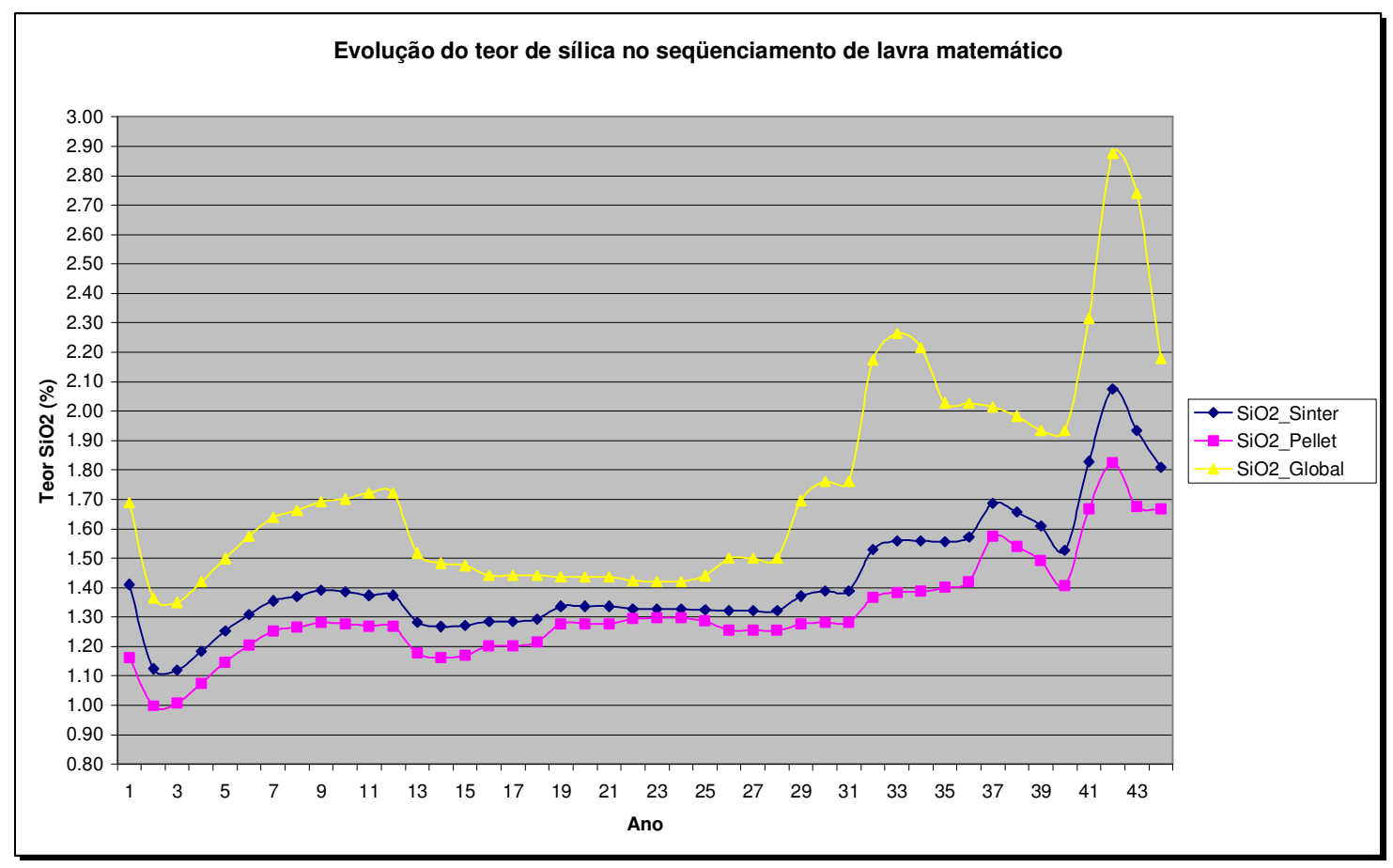

Figura 20 - Gráfico da evolução da SiO2 no seqüenciamento matemático Fonte - Carvalho e De Tomi, 2009

Devido ao exposto acima e ao foco do estudo, o seqüenciamento matemático não atendeu às premissas principais, que são exaurir de uma forma ordenada áreas da mina para a disposição de estéril considerando os parâmetros técnicos e econômicos, isso quer dizer também levar em conta a estacionarização das variáveis no decorrer dos anos.

Todo o seqüenciamento de lavra foi revisado manualmente conforme metodologia específica descrita no Capítulo 3.

A partir da revisão do seqüenciamento de lavra, a responsabilidade passou a ser exclusivo da Diretoria de Ferrosos Longo Prazo (DIPF), essa revisão é datada de julho/2007. 


\subsubsection{Análise da geologia local}

A geologia de Serra Sul possue corpos extensos e rasos, dessa forma viabiliza positivamente a metodologia descrita nesse trabalho, conforme Figuras 21 e 22, pois não se corre o risco de dispor estéril em cima de potencial reserva futura.

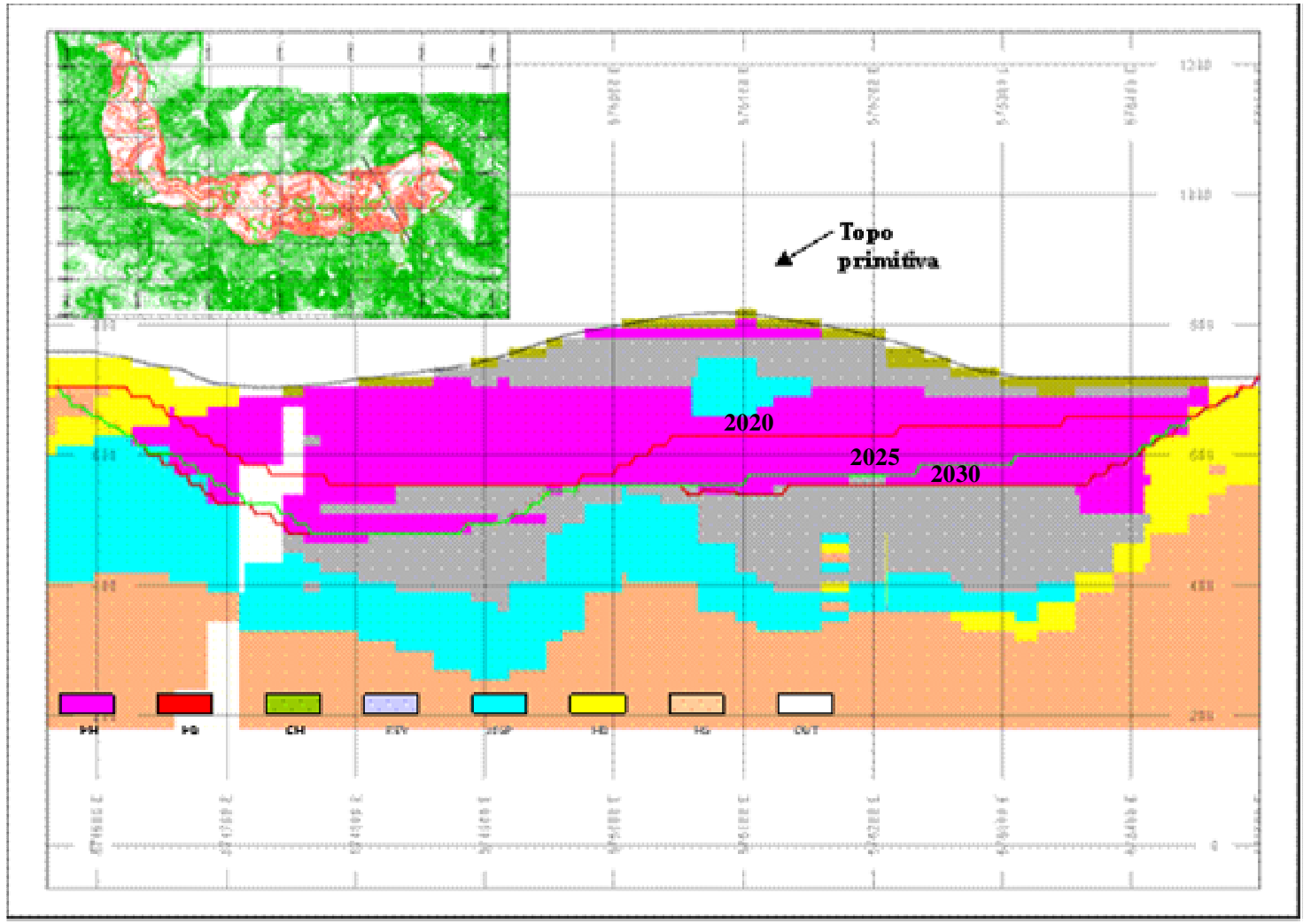

Figura 21 - Seção vertical típica de Serra Sul

Fonte - Relatório Serra Sul Fel 3 - Relatório interno Vale, Mar/2008

Em função da paralização das sondagens por falta de licenciamento ambiental, a informação geológica disponível foi à mesma utilizada no modelo geológico de maio de 2007. Oportunamente, com a retomada da campanha de sondagem, os refinamentos no modelo geológico-geotécnico demandarão revisão do planejamento de lavra e do dimensionamento de frota. 


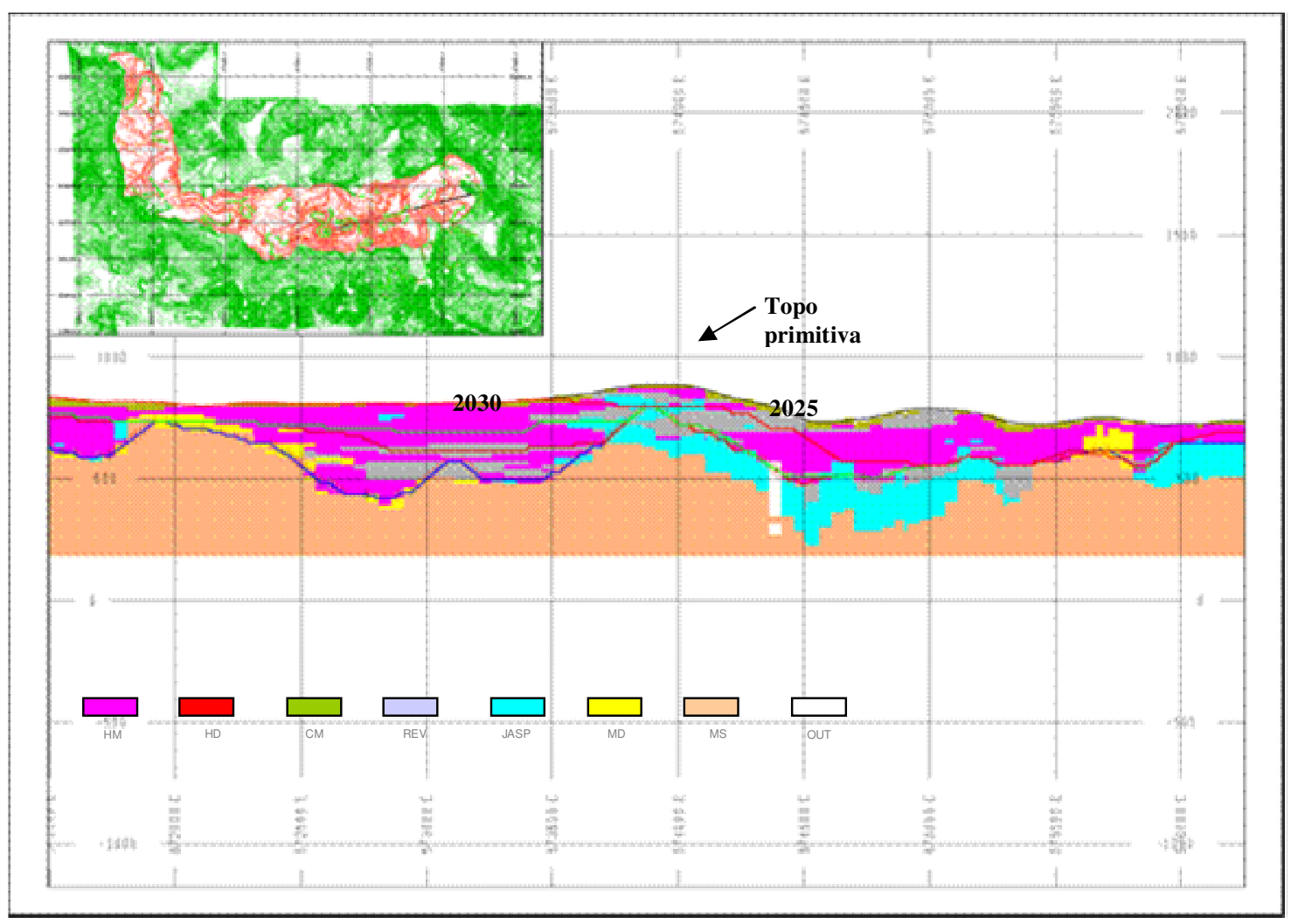

Figura 22 - Seção vertical típica de Serra Sul

Fonte - Relatório Serra Sul Fel 3 - Relatório interno Vale, Mar/2008

\subsubsection{Análise da malha de sondagem}

Análise da malha de sondagem da região, verificando se a área de interesse do ínicio da lavra possui um nível de informação apropriado ou se existe um tempo disponível para fechar a malha de sondagem até o ínicio das operações da mina, viabilizando, dessa forma, uma maior segurança na lavra do minério da região e também na disposição de estéril futura, minimizando o risco de dispor estéril em áreas potenciais de minério. 


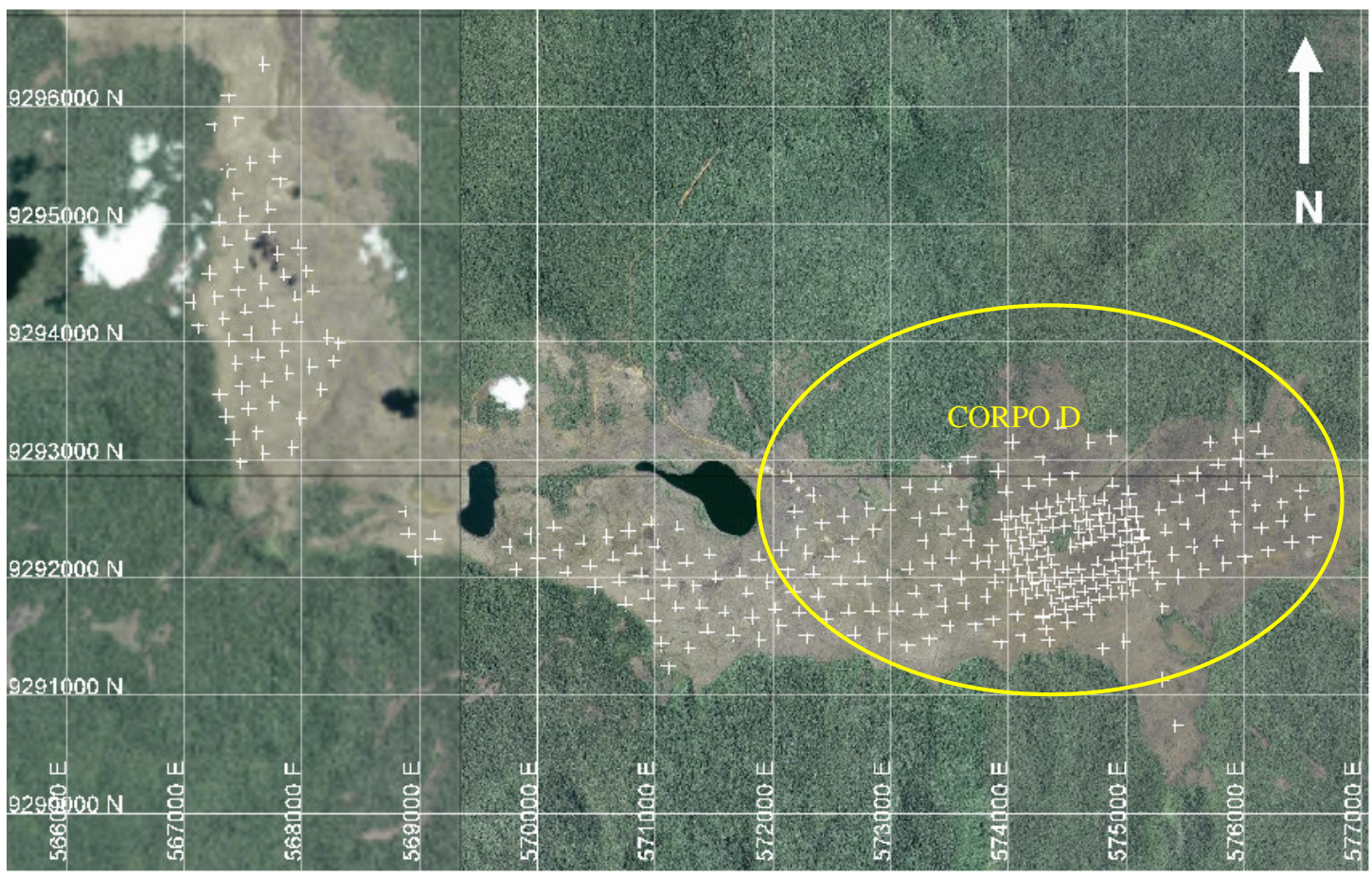

Figura 23 - Malha de sondagem nos corpos C e D do alvo S11

Fonte - Relatório de Avaliação de Recursos de Serra Sul, Relatório interno Vale, Set/2008

Até o ano de 2008, a jazida de serra sul tem as informações de malha de sondagem descrita na Figura 23 acima.

A malha de sondagem no corpo D é de $200 \times 200$ m e $100 \times 100 m$ enquanto que no corpo C é $200 \times 200 \mathrm{~m}$.

Inicialmente, nesse estudo, a lavra de Serra Sul estava programada para o ano de 2011, esse é um tempo também para ser concedido o licenciamento ambiental para pesquisa e continuar a sondagem na região.

\subsubsection{Estudo geotécnico}

Para a avaliação dos possíveis ângulos de talude da cava, tanto final quanto operacional, deverão ser realizados estudos geomecânicos detalhados dos diferentes tipos de materiais existentes. Tais estudos compreendem, entre outros, a 
determinação das principais estruturas geológicas, conhecimento hidrogeológico da região e ensaios geotécnicos. Partindo destas informações, o modelo poderá ser criado, indicando os ângulos de talude médios, conforme as características geotécnicas de cada setor da mina.

A princípio, o ângulo de estabilidade considerado para determinação da cava preliminar concebida para esta mina foi correlacionado ao tipo de material (minério ou estéril). Adotou-se serem os mesmos utilizados da mina N4E, ora em lavra em Carajás. Os setores podem ser vistos na Figura 24 a seguir.

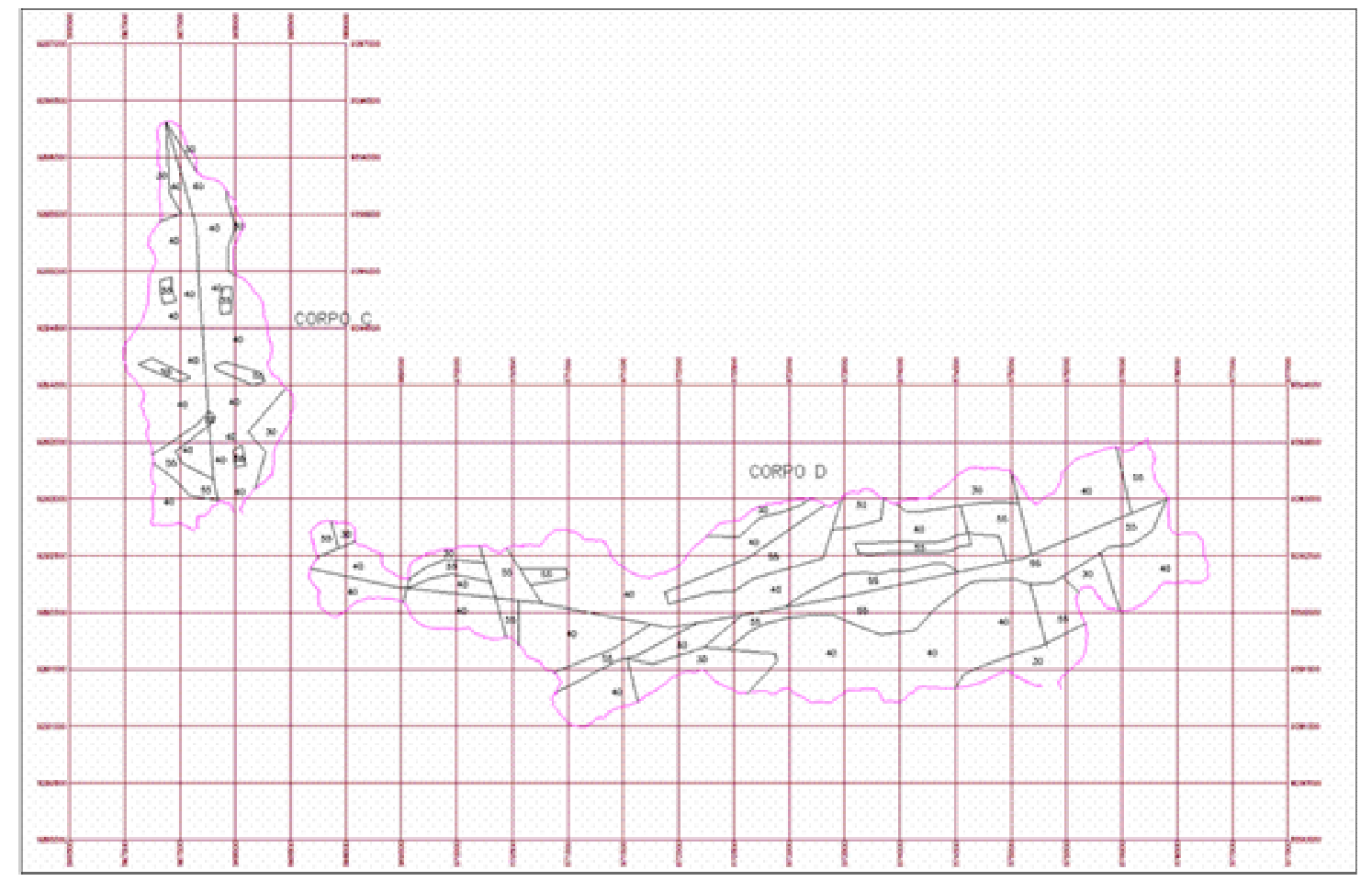

Figura 24 - Croqui sem escala dos setores geotécnicos de Serra Sul Fonte - Carvalho e De Tomi, 2009

Regra geral é de extrema importância o estudo geotécnico das áreas onde será efetuada a disposição do estéril lavrado. Tal estudo garante a segurança dos bancos que ficarão na encosta. Não é o caso desta seqüencia de lavra, pois, todo o estéril nessa revisão foi considerado confinado dentro da cava. 


\subsubsection{Avaliação por área da cava}

Avaliação por área da cava para o conhecimento da qualidade e da relação estéril minério por região da mina. Em minas com o tipo de minério homogêneo há uma segurança maior na adaptação da metodologia, pois não se prejudica a estacionarização da qualidade nos anos correntes.

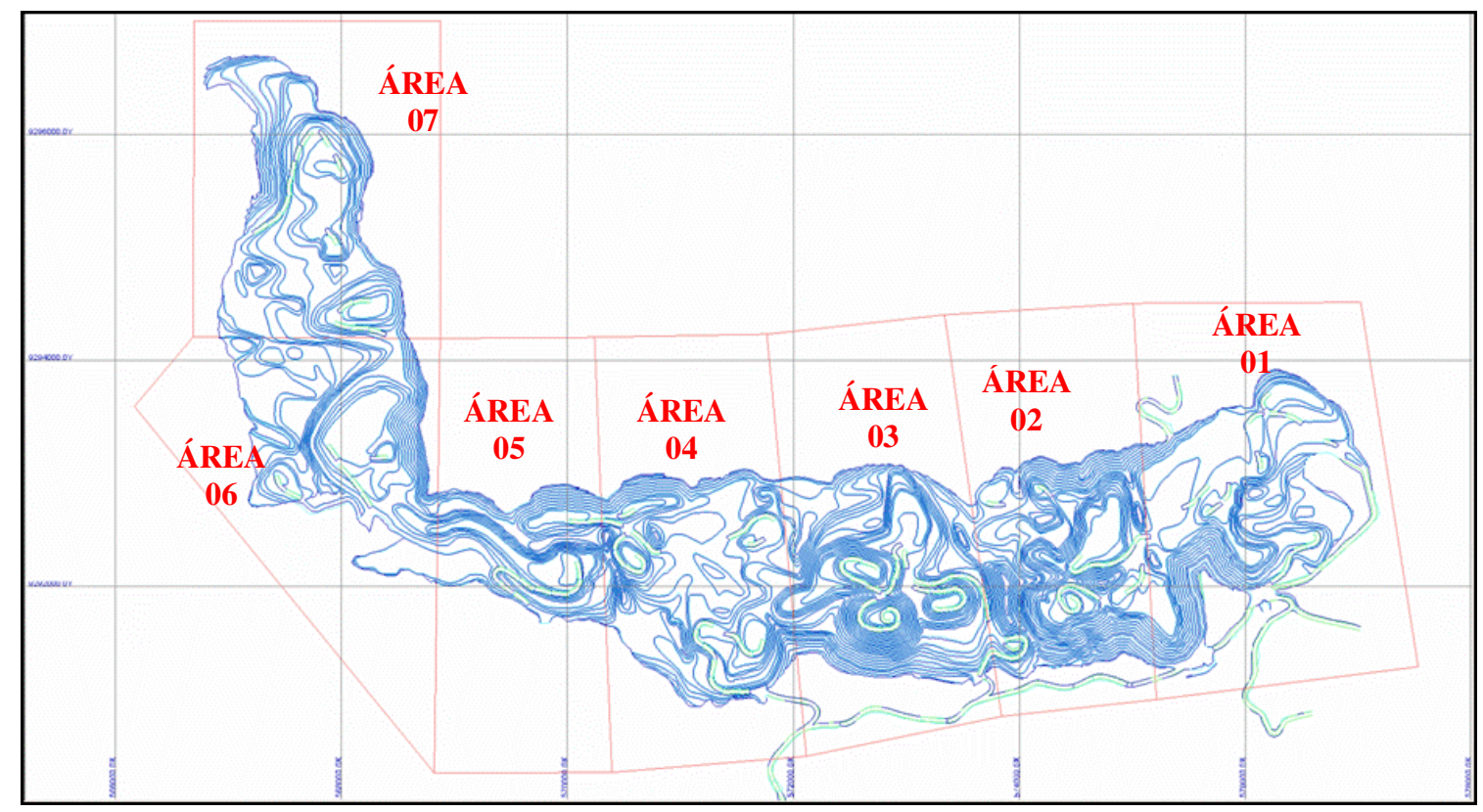

Figura 25 - Cava de Serra Sul dividida por áreas Fonte - Carvalho e De Tomi, 2009

De acordo com a análise realizada por área da mina, conforme a Figura 25, a qualidade do minério é homogêneo, com áreas de maior (1.34) e menor Relação Estéril/Minério (0.54).

Foi constatado que a Área 01 é uma das regiões de menor RE/M de Serra Sul, onde poderá ser o ínicio da lavra com o intuito de exauri-la objetivando dispor estéril concomitantemente à lavra futura. 


\subsubsection{Seqüenciamento de lavra ordenado}

Com as análises preliminares descritas e realizadas anteriormente, temos 0 embasamento necessário para realizar o seqüenciamento de lavra ordenado, iniciando a lavra pela extremidade do corpo.

Como premissa para o seqüenciamento de lavra, adotou-se a estratégia de iniciar a lavra pela extremidade leste do corpo $\mathrm{D}$ e dar seguimento da lavra na direção oeste, de forma a criar condições para a colocação de estéril dentro da cava nos anos posteriores, ou seja, se propõe uma lavra no sentido leste-oeste, de forma ordenada. Observar a Figura 26 que mostra o ínicio da lavra de Serra Sul.

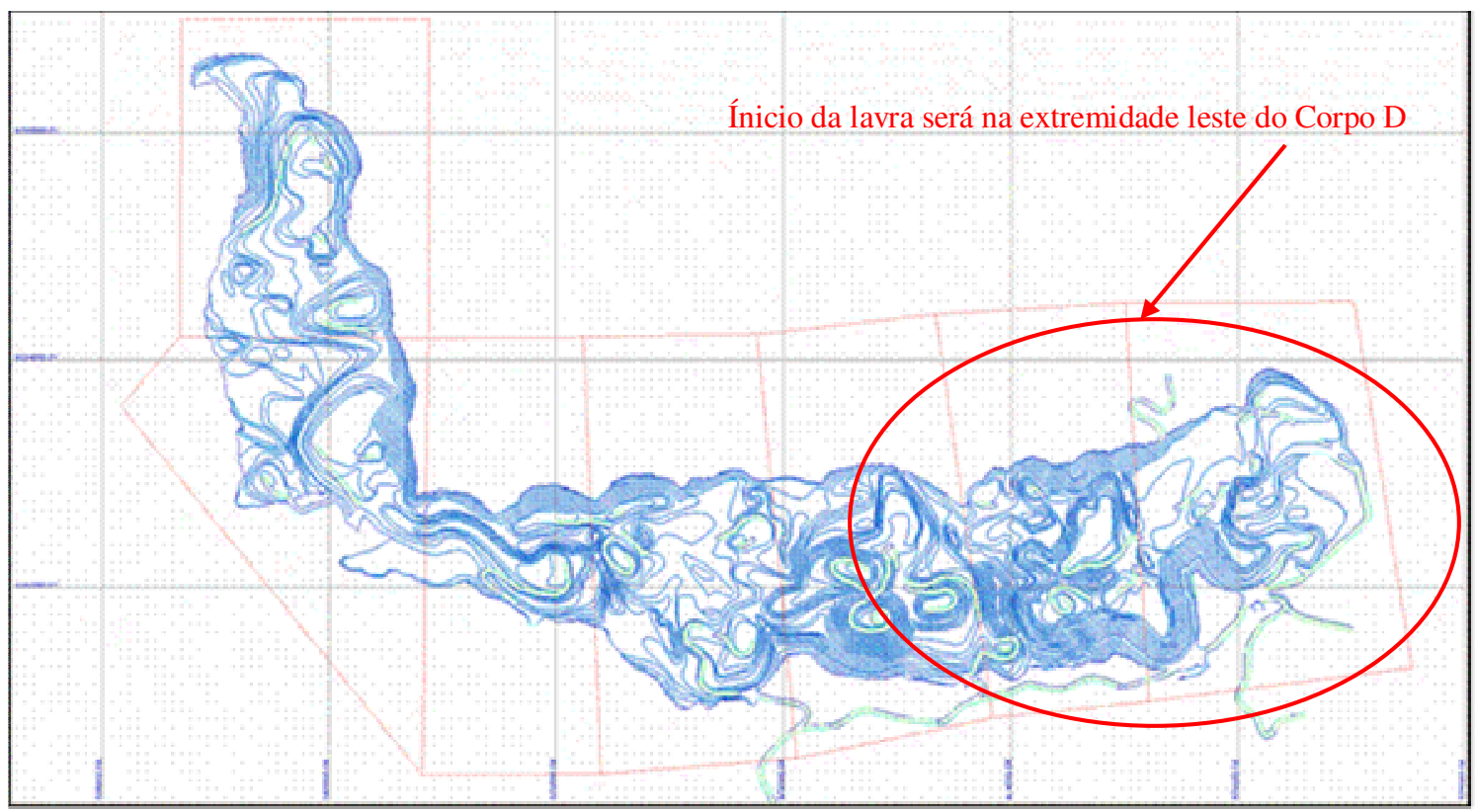

Figura 26 - Croqui sem escala do indicativo de onde será o ínicio da lavra de Serra Sul Fonte - Carvalho e De Tomi, 2009

O corpo $\mathrm{D}$ também é onde se encontra a malha de sondagem mais adensada, isto é, a área onde há maior precisão no modelamento geológico e estimativa de teores.

A lavra do corpo D será iniciada em locais com menor incidência de feições sujeitas a restrições ambientais como grutas e lagoas. 
Nesse primeiro momento, a lavra do minério de Serra Sul é uma operação convencional, em bancadas de 15 metros de altura, começando em meia encosta e passando para uma lavra em cava com a evolução dos trabalhos mineiros. A rampa máxima praticada foi de 10\%, com a largura dos acessos de $35 \mathrm{~m}$. Estão sendo feitos outros estudos, nessa mina, para a implementação de sistema contínuo de lavra (correias).

Quanto aos equipamentos principais de lavra, foram gerados dois cenários para o dimensionamento dos equipamentos de carga e transporte, baseados em caminhões de $240 t$ e 363t, tendo sido escolhido o cenário com caminhões de 363t.

Optou-se, no dimensionamento, por um equilíbrio nos equipamentos de carga entre escavadeiras a cabo, hidráulicas e as carregadeiras frontais sobre pneus, buscando maior agilidade na frota selecionada.

As geometrias que estão representadas pela crista em vermelho significam que tais bancos estão encostando no limite final da cava no ano de referência.

O Ano 07 (2017) já apresenta a disposição de estéril dentro da cava (crista em laranja), mas, é no Ano 15 (2025), conforme Figura 27 e 28, que inicia a disposição de estéril dentro da mina de forma mais acentuada. Todo o seqüenciamento de lavra pode ser visto com mais detalhes no Anexo 03. 


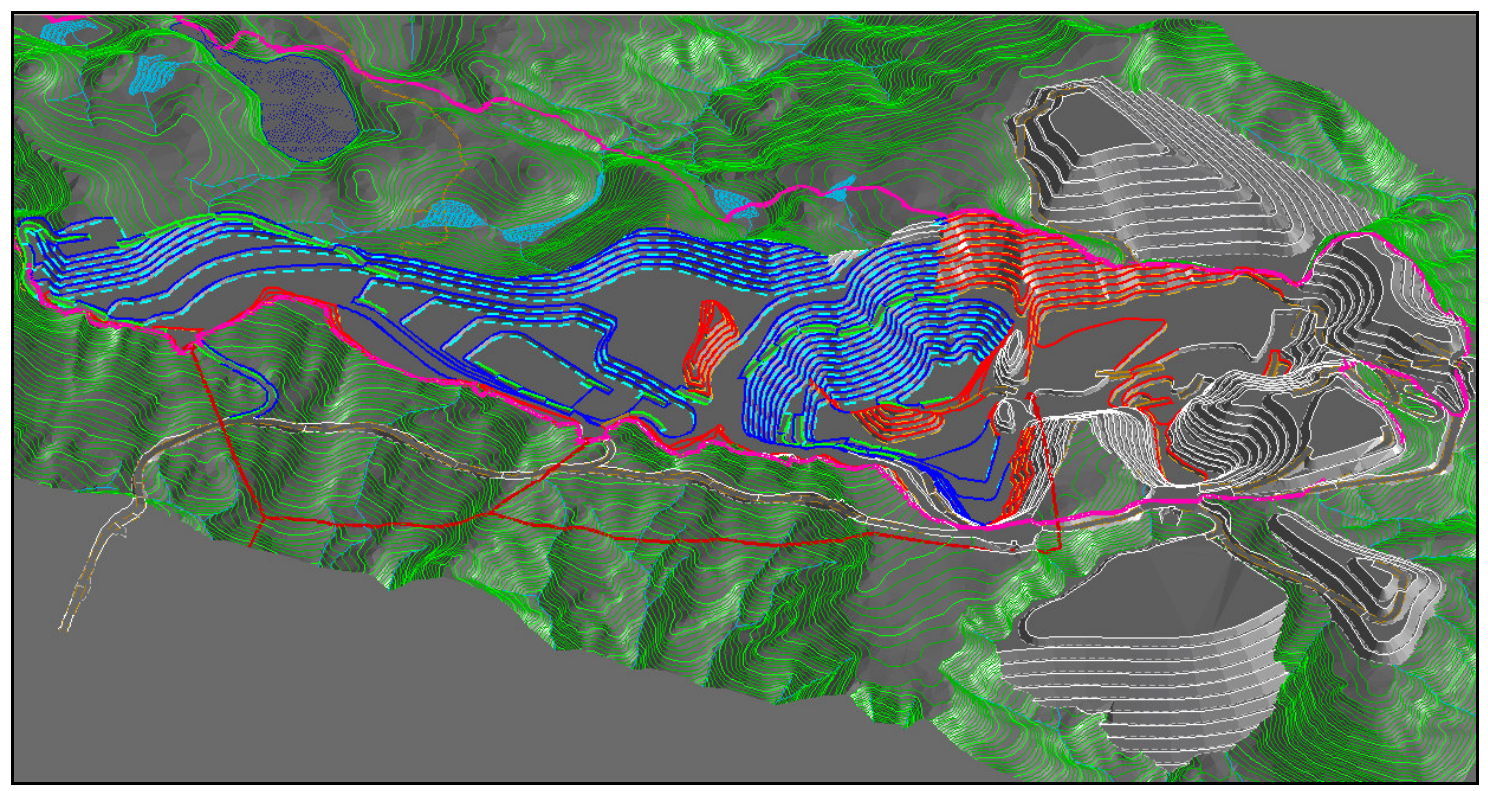

Figura 27 - Croqui sem escala do plano de lavra ano 15

Fonte - Relatório Serra Sul Fel 3 - Relatório interno Vale, Mar/2008

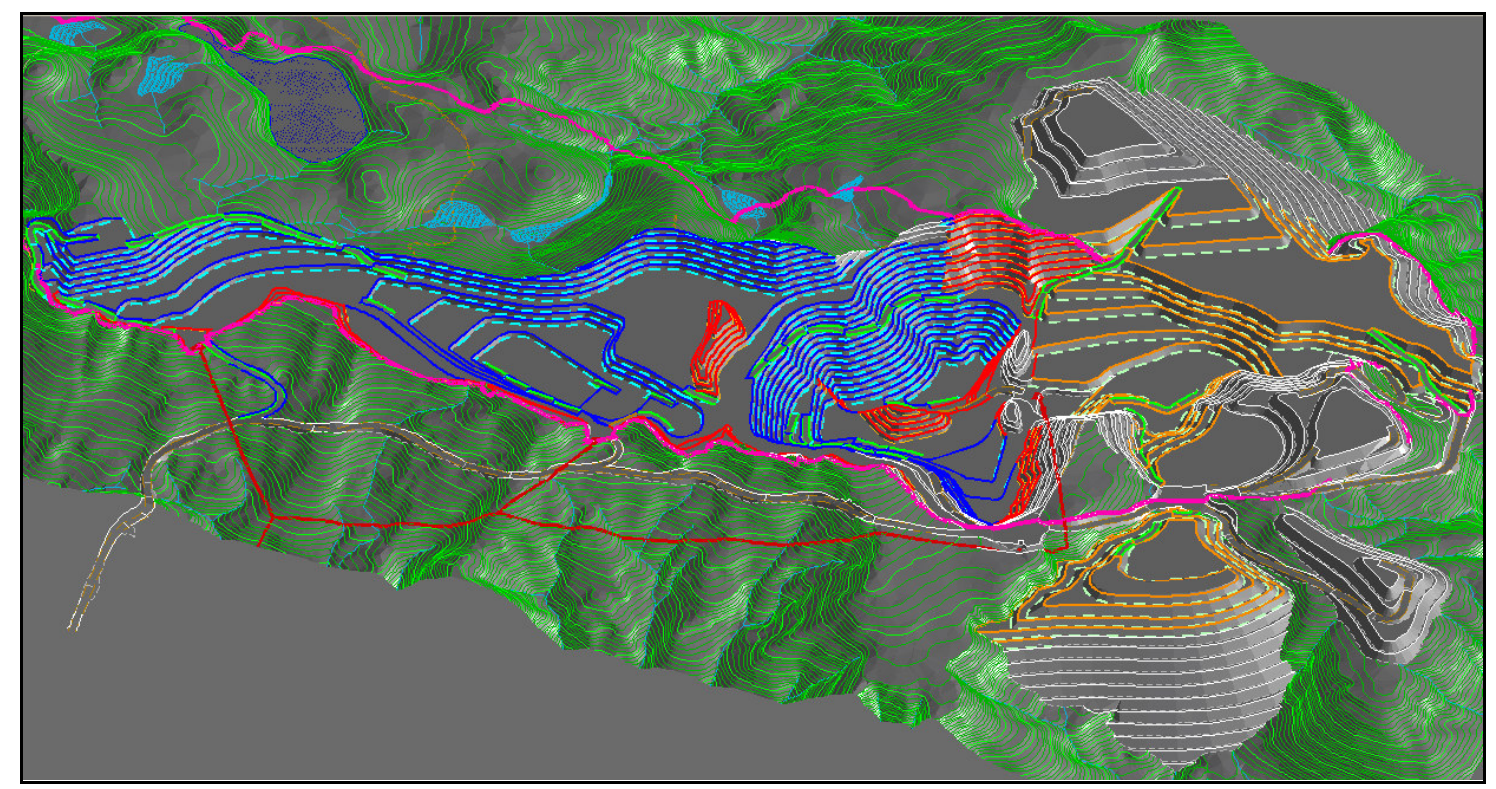

Figura 28 - Croqui sem escala do plano de lavra e disposição de estéril ano 15 Fonte - Relatório Serra Sul Fel 3 - Relatório interno Vale, Mar/2008 
Tabela 3 - Plano de produção da lavra

Fonte - Relatório Serra Sul Fel 3 - Relatório interno Vale, Mar/2008

\begin{tabular}{|c|c|c|c|c|c|c|c|c|c|c|c|}
\hline \multirow{3}{*}{ Ano } & \multicolumn{9}{|c|}{ Minério } & \multirow{3}{*}{$\begin{array}{c}\text { Estéril } \\
\text { (Mt) }\end{array}$} & \multirow{3}{*}{$\begin{array}{c}\text { Mov. } \\
\text { Total } \\
(\mathrm{Mt})\end{array}$} \\
\hline & \multirow{2}{*}{ Litologia } & \multirow{2}{*}{$\begin{array}{c}\text { Massas } \\
(\mathrm{Mt})\end{array}$} & \multicolumn{7}{|c|}{ Teores Médios ( \% ) } & & \\
\hline & & & $\mathrm{Fe}_{2} \mathrm{O}_{3}$ & $\mathrm{SiO}_{2}$ & $\mathrm{P}$ & $\mathrm{Al}_{2} \mathrm{O}_{3}$ & $\mathrm{Mn}$ & $\mathrm{Mg}$ & PPC & & \\
\hline \multirow{3}{*}{ Ano 0} & $\mathrm{HM}$ & 2.87 & 66.12 & 1.81 & 0.033 & 0.66 & 0.24 & 0.042 & 2.40 & \multirow{3}{*}{23.50} & \multirow{3}{*}{26.37} \\
\hline & $\mathrm{HD}$ & & & & & & & & & & \\
\hline & Total & 2.87 & 66.12 & 1.81 & 0.033 & 0.66 & 0.24 & 0.042 & 2.40 & & \\
\hline \multirow{3}{*}{ Ano 1} & $\mathrm{HM}$ & 58.39 & 65.83 & 1.20 & 0.042 & 0.92 & 0.12 & 0.043 & 2.75 & \multirow{3}{*}{30.16} & \multirow{3}{*}{88.55} \\
\hline & $\mathrm{HD}$ & & & & & & & & & & \\
\hline & Total & 58.39 & 65.83 & 1.20 & 0.042 & 0.92 & 0.12 & 0.043 & 2.75 & & \\
\hline \multirow{3}{*}{ Ano 2} & $\mathrm{HM}$ & 84.49 & 65.94 & 1.38 & 0.036 & 0.77 & 0.11 & 0.044 & 2.70 & \multirow{3}{*}{38.09} & \multirow{3}{*}{122.57} \\
\hline & $\mathrm{HD}$ & & & & & & & & & & \\
\hline & Total & 84.49 & 65.94 & 1.38 & 0.036 & 0.77 & 0.11 & 0.044 & 2.70 & & \\
\hline \multirow{3}{*}{ Ano 3} & $\mathrm{HM}$ & 109.58 & 66.07 & 1.12 & 0.039 & 0.65 & 0.15 & 0.044 & 2.49 & \multirow{3}{*}{48.60} & \multirow{3}{*}{158.18} \\
\hline & $\mathrm{HD}$ & & & & & & & & & & \\
\hline & Total & 109.58 & 66.07 & 1.12 & 0.039 & 0.65 & 0.15 & 0.044 & 2.49 & & \\
\hline \multirow{3}{*}{$\begin{array}{c}\text { Ano } 4 \text { a } \\
\text { Ano } 5\end{array}$} & $\mathrm{HM}$ & 218.88 & 65.96 & 1.03 & 0.041 & 0.65 & 0.15 & 0.045 & 2.43 & \multirow{3}{*}{94.25} & \multirow{3}{*}{313.84} \\
\hline & $\mathrm{HD}$ & 0.71 & 63.90 & 1.97 & 0.068 & 1.62 & 0.05 & 0.040 & 3.01 & & \\
\hline & Total & 219.59 & 65.95 & 1.03 & 0.041 & 0.65 & 0.15 & 0.045 & 2.43 & & \\
\hline \multirow{3}{*}{$\begin{array}{c}\text { Ano } 6 \text { a } \\
\text { Ano } 7\end{array}$} & $\mathrm{HM}$ & 219.87 & 65.97 & 1.21 & 0.039 & 0.69 & 0.26 & 0.044 & 2.40 & \multirow{3}{*}{112.80} & \multirow{3}{*}{332.67} \\
\hline & $\mathrm{HD}$ & & & & & & & & & & \\
\hline & Total & 219.87 & 65.97 & 1.21 & 0.039 & 0.69 & 0.26 & 0.044 & 2.40 & & \\
\hline & $\mathrm{HM}$ & 324.18 & 65.80 & 1.26 & 0.039 & 0.97 & 0.14 & 0.044 & 2.77 & & \\
\hline Ano 8 a & $\mathrm{HD}$ & 1.21 & 65.69 & 1.30 & 0.092 & 0.78 & 0.04 & 0.033 & 3.85 & 200.74 & 526.12 \\
\hline & Total & 325.39 & 65.80 & 1.26 & 0.039 & 0.97 & 0.14 & 0.044 & 2.78 & & \\
\hline & $\mathrm{HM}$ & 541.39 & 65.97 & 1.27 & 0.040 & 0.88 & 0.11 & 0.040 & 2.41 & & \\
\hline $\begin{array}{c}\text { Ano } 11 \text { a } \\
\text { Ano } 15\end{array}$ & $\mathrm{HD}$ & 1.41 & 64.60 & 1.90 & 0.088 & 1.24 & 0.05 & 0.036 & 4.20 & 339.02 & 881.81 \\
\hline & Total & 542.80 & 65.97 & 1.27 & 0.040 & 0.88 & 0.11 & 0.040 & 2.42 & & \\
\hline & $\mathrm{HM}$ & 546.20 & 65.61 & 1.51 & 0.042 & 1.03 & 0.08 & 0.039 & 2.72 & & \\
\hline $\begin{array}{c}\text { Ano } 16 \text { a } \\
\text { Ano } 20\end{array}$ & $\mathrm{HD}$ & 0.08 & 63.47 & 2.33 & 0.093 & 1.69 & 0.05 & 0.040 & 4.49 & 253.01 & 799.29 \\
\hline & Total & 546.28 & 65.61 & 1.51 & 0.042 & 1.03 & 0.08 & 0.039 & 2.72 & & \\
\hline & $\mathrm{HM}$ & $2,613.95$ & 66.26 & 1.48 & 0.035 & 0.66 & 0.16 & 0.046 & 2.20 & & \\
\hline $\begin{array}{l}\text { Ano } 21 \text { a } \\
\text { Final }\end{array}$ & $\mathrm{HD}$ & 15.34 & 64.05 & 1.89 & 0.069 & 1.17 & 0.05 & 0.038 & 4.01 & 953.15 & $3,582.44$ \\
\hline & Total & $2,629.28$ & 66.24 & 1.48 & 0.035 & 0.66 & 0.16 & 0.046 & 2.21 & & \\
\hline & $\mathrm{HM}$ & $4,719.80$ & 66.08 & 1.40 & 0.038 & 0.75 & 0.15 & 0.044 & 2.37 & & \\
\hline TOTAL ${ }^{(1)}$ & $\mathrm{HD}$ & 18.74 & 64.19 & 1.85 & 0.072 & 1.17 & 0.05 & 0.038 & 3.98 & $2,093.32$ & $6,831.85$ \\
\hline & Total & $4,738.54$ & 66.07 & 1.40 & 0.038 & 0.75 & 0.15 & 0.044 & 2.37 & & \\
\hline
\end{tabular}

A tabela acima demonstra a produção por ano programada para a mina, sendo que a partir do ano 15 (2025) que existe uma disposição maior do material estéril lavrado dentro da mina. 


\subsection{DEPÓSITO DE ESTÉRIL}

\subsubsection{Depósito de estéril convencional}

Originalmente, foram programados 03 depósitos de estéril para Serra Sul e também nesse estudo de caso nos primeiros anos para a lavra da mina ainda é necessário preparar áreas de depósito de estéril fora da cava, visando receber o material a ser lavrado.

A litologia predominante de estéril é a canga de minério, tal tipo de material pode ser aproveitado esporadicamente na usina.

As posições dos depósitos foram definidas pela área de lavra, compondo 03 pilhas de estéril no lado sul da Serra. As geometrias avaliadas e propostas não levam em consideração volumes de minério ou de estéril, que não foram fornecidos pela lavra no início dos trabalhos. As geometrias foram estabelecidas para se conhecer qual volume de estocagem poderiam garantir. Com base nestes volumes, e nas posições das pilhas, a lavra irá avaliar nas próximas fases quais são as pilhas mais adequadas para o empreendimento e que volumes destas pilhas serão utilizados.

Para cada uma das opções foi determinado o volume de armazenamento das mesmas. Não se considerou um volume de material e se buscou um depósito com o volume requerido.

Esta premissa resulta na constatação de que uma vez definido o volume requerido, podem ser efetuadas alterações na geometria da pilha para sua otimização, seja em termos de área de ocupação do terreno seja em termos de altura.

A pilha de estéril 01 situa-se no lado sul da Serra, na sua parte oeste. A sua área de implantação mostra a topografia com pequenos vales, de modo que a sua geometria pode ser classificada como pilha de encosta, não havendo encostas laterais que 
possam restringir sua expansão. Com isto, esta pilha poderá no futuro, se houver demanda de volume para esta área, ser ampliada lateralmente, de preferência no sentido oeste, pois para leste há outras drenagens, o que implica em maiores custos com obras de drenagem interna.

Os vales de drenagem têm seu fluxo direcionado para o lado oeste, no sentido da bacia do rio Itacaiúnas, que está cerca de $11 \mathrm{~km}$ de distância.

A pilha de estéril 02 poderá ser também implantada em vale de menor expressão, tendo o seu lado leste representado por encosta natural e o seu lado oeste como depósito de encosta, apoiando-se apenas no lado sul. A sua expansão para o lado oeste, com objetivo de aumento de volume de armazenamento, levará sua geometria a ser semelhante à da pilha de estéril 01 .

O vale onde está instalada a pilha 02 também drena para o rio Itacaiúnas, estando um pouco mais distante do que no caso da pilha 01 , da ordem de $14 \mathrm{~km}$. Esta pilha está posicionada também no lado sul de Serra Sul, mais para leste em relação à pilha 01 e aproximadamente na parte central de Serra Sul.

A pilha de estéril 03 também se localiza ao sul da Serra, no seu extremo leste. $O$ vale drena no sentido oposto ao do rio Itacaiúnas havendo, pois um divisor de águas entre os vales desta pilha e aqueles das pilhas 01 e 02.

Considerando a geração estimada de estéril de $163 \mathrm{Mm}^{3}$, definida ao fim destes estudos, existe suficiente capacidade de estocagem na área para todo estéril a ser gerado.

O estéril a ser escavado na mina constituir-se-á basicamente de solo - de rocha máfica decomposta - e subordinadamente jaspilito, os quais serão dispostos em conjunto. Assim sendo, a favor da segurança, entende-se que o comportamento das pilhas será ditado pelo comportamento do solo, de menor resistência.

Não há ensaios geotécnicos disponíveis dos materiais e, portanto, para uma avaliação da estabilidade dos depósitos adotam-se parâmetros de outros projetos de 
disposição de estéril, tanto publicados na literatura nacional como de nossa experiência em projetos semelhantes.

A Figura 29 mostra a geometria das pilhas de estéril 01, 02 e 03.

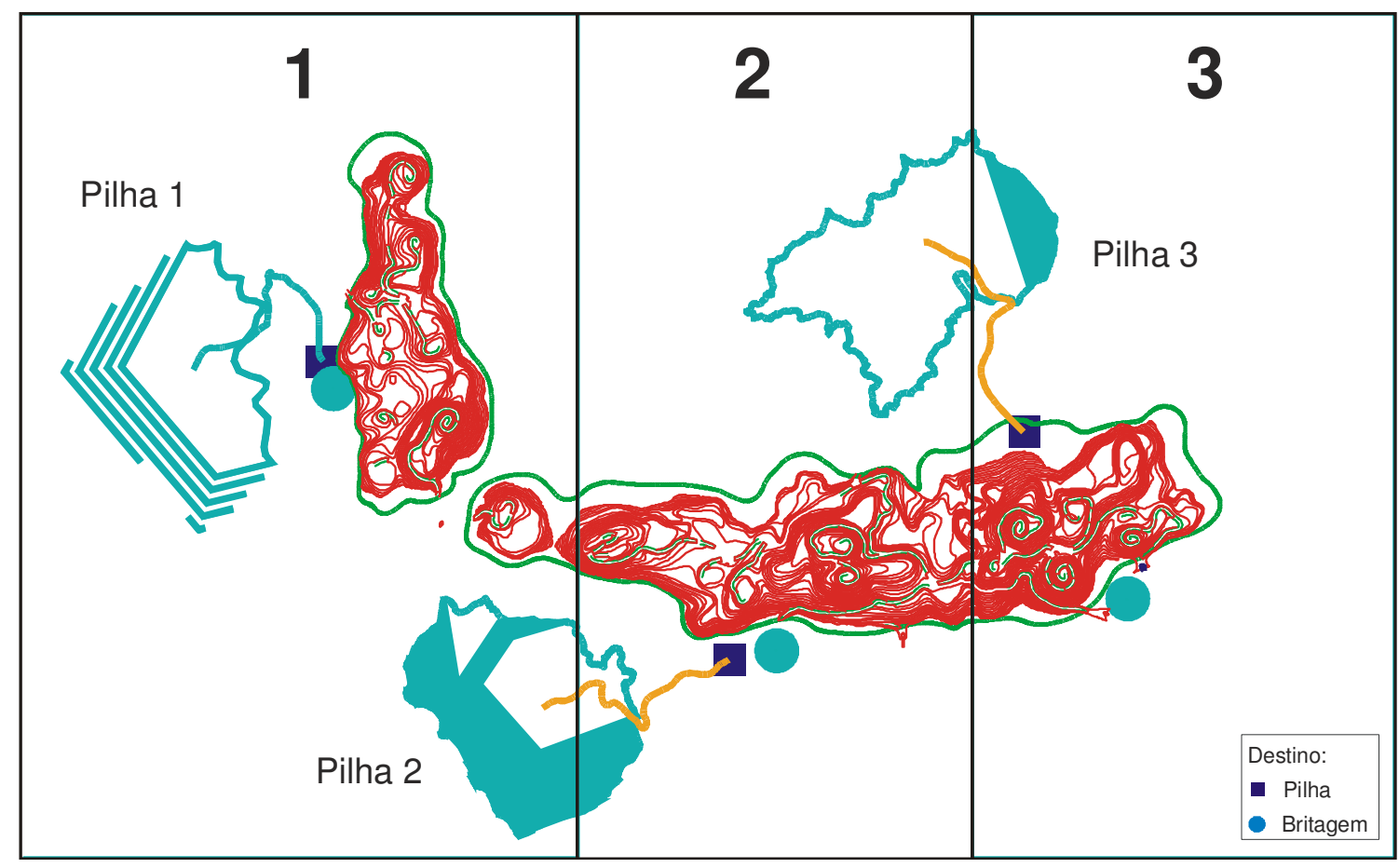

Figura 29 - Croqui sem escala da geometria dos depósitos de estéril 01, 02 e 03 Fonte - Relatório Serra Sul Fel 3 - Relatório interno Vale, Mar/2008

O arranjo geral dos depósitos e sua geometria básica e a geometria dos bancos foi definida a partir da recomendação da norma ABNT NBR 13029, de julho/1993, quanto à largura das bermas $(6 \mathrm{~m})$ e quanto à altura dos bancos $(10 \mathrm{~m})$. A altura total é superior em alguns casos àquela recomendada na norma, de $200 \mathrm{~m}$, tendo em vista que na avaliação da estabilidade os depósitos se mostram com coeficientes de segurança ainda adequados, mesmo para as alturas maiores que foram projetadas, de até $275 \mathrm{~m}$.

É necessário observar que estas geometrias são preliminares, tendo sido definidas sem investigações geotécnicas tanto dos materiais estéreis e minérios como do terreno de fundação. 
Para as alturas avaliadas, os coeficientes de segurança situam-se em torno de 1,4 a 1,5 , considerados adequados para o tipo de depósito que se pretende implantar.

Os bancos individuais serão construídos por basculamento em ponta de aterro, em camadas com $10 \mathrm{~m}$ de altura. Do ponto de vista de estabilidade o ideal seria formar o depósito em camadas de espessuras menores, o que teria também um benefício adicional de resultar em aterro com densidade maior e, portanto, melhor taxa de ocupação do terreno.

Como o material basculado em geral mostra um ângulo de talude da ordem de $34^{\circ}$ (variando de 33 a $37^{\circ}$ ), que é o próprio ângulo de repouso natural, o mesmo deverá ser abrandado para o valor de 26을 recomendado pela norma NBR 13029.

As pilhas serão construídas em camadas, de no máximo $10 \mathrm{~m}$ de espessura, em ponta de aterro ou espalhadas, no sentido ascendente do vale, ou seja, de baixo para cima.

Assim, à medida que cada banco de $10 \mathrm{~m}$ é completado, procede-se ao acerto do talude, revestindo-o em seguida com vegetação rasteira, tais como gramíneas, para proteção contra erosão e para melhorar o aspecto visual.

À medida em que se progride com a construção da pilha, serão instalados instrumentos na mesma, (piezômetros e indicadores de nível de água), que permitam monitorar o nível de água no interior do depósito, além de, marcos de superfície. Também serão instalados marcos de concreto, para controle topográfico de possíveis movimentações. Logo à jusante da saída do dreno de fundo, será instalado um medidor de vazão triangular, para monitorar o funcionamento do dreno e o comportamento das vazões ao longo do tempo. Além da vazão, será também monitorada a qualidade físico-química do efluente final da pilha.

Foi considerada a construção de diques de contenção nas áreas das pilhas cuja função é a contenção dos sólidos erodidos, tanto na etapa de preparo do terreno de fundação, como na etapa construtiva da pilha. Por isto, estes diques são localizados 
a jusante do pé das pilhas, em posição tal que receba a drenagem do canal periférico e não inunde a saída do dreno de fundo da pilha.

\subsubsection{Depósito de estéril dentro da cava}

O Projeto de Serra Sul tem como objetivo o seqüenciamento de lavra e disposição de estéril simultâneo e ordenado, para que seja viabilizada a disposição de estéril em áreas estratégicas dentro da mina que estejam em limite final de escavação

Essa disposição já pode ser percebida a partir do Ano 07 (2017), mas, com ênfase no seqüenciamento de lavra a partir dos anos 15 (2025) e 20 (2030), observar Figura 30 e 31.

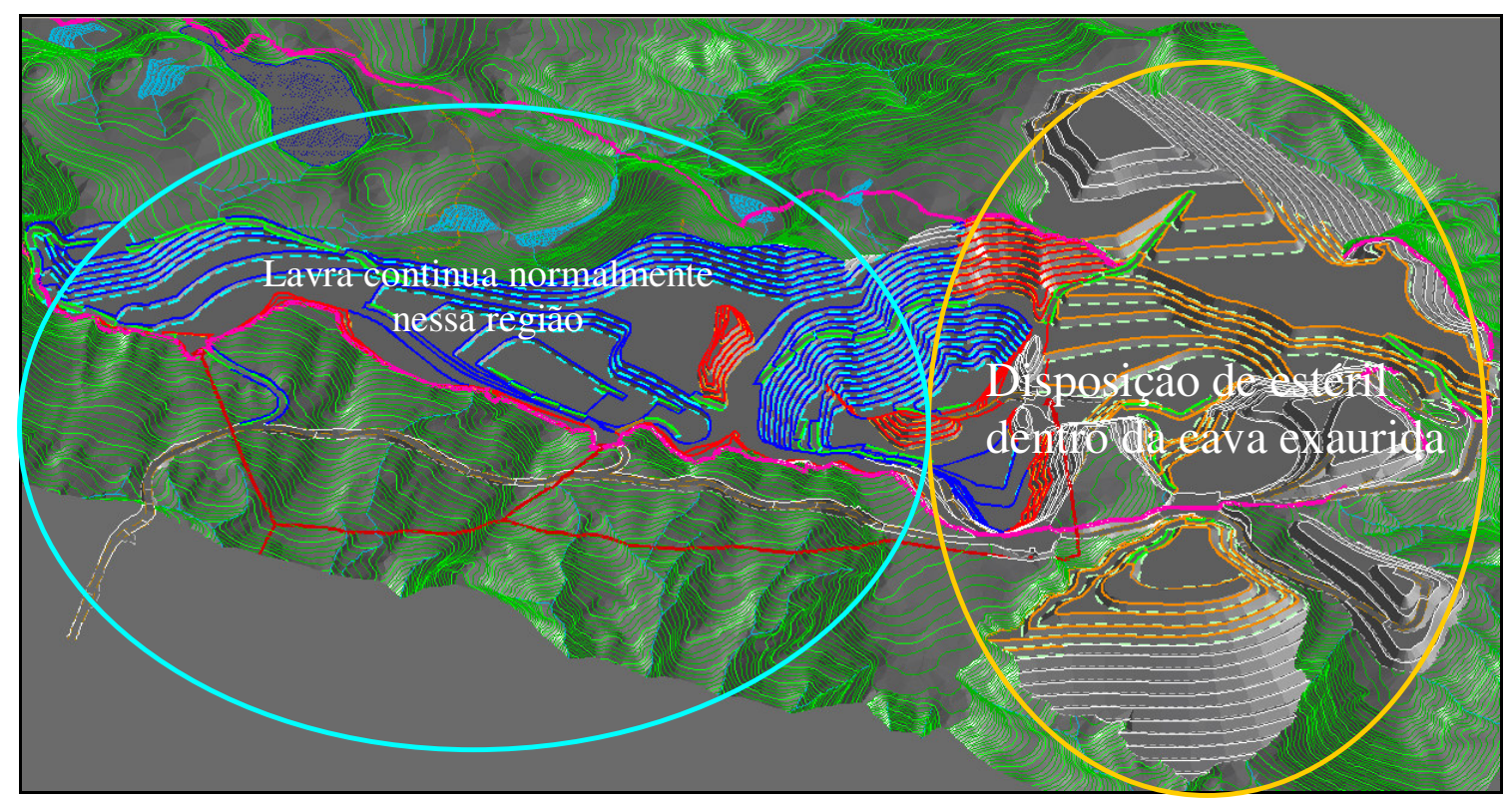

Figura 30 - Croqui sem escala ano 15 (2025) lavra concomitante com a disposição de estéril dentro da mina

Fonte - Relatório Serra Sul Fel 3 - Relatório interno Vale, Mar/2008 


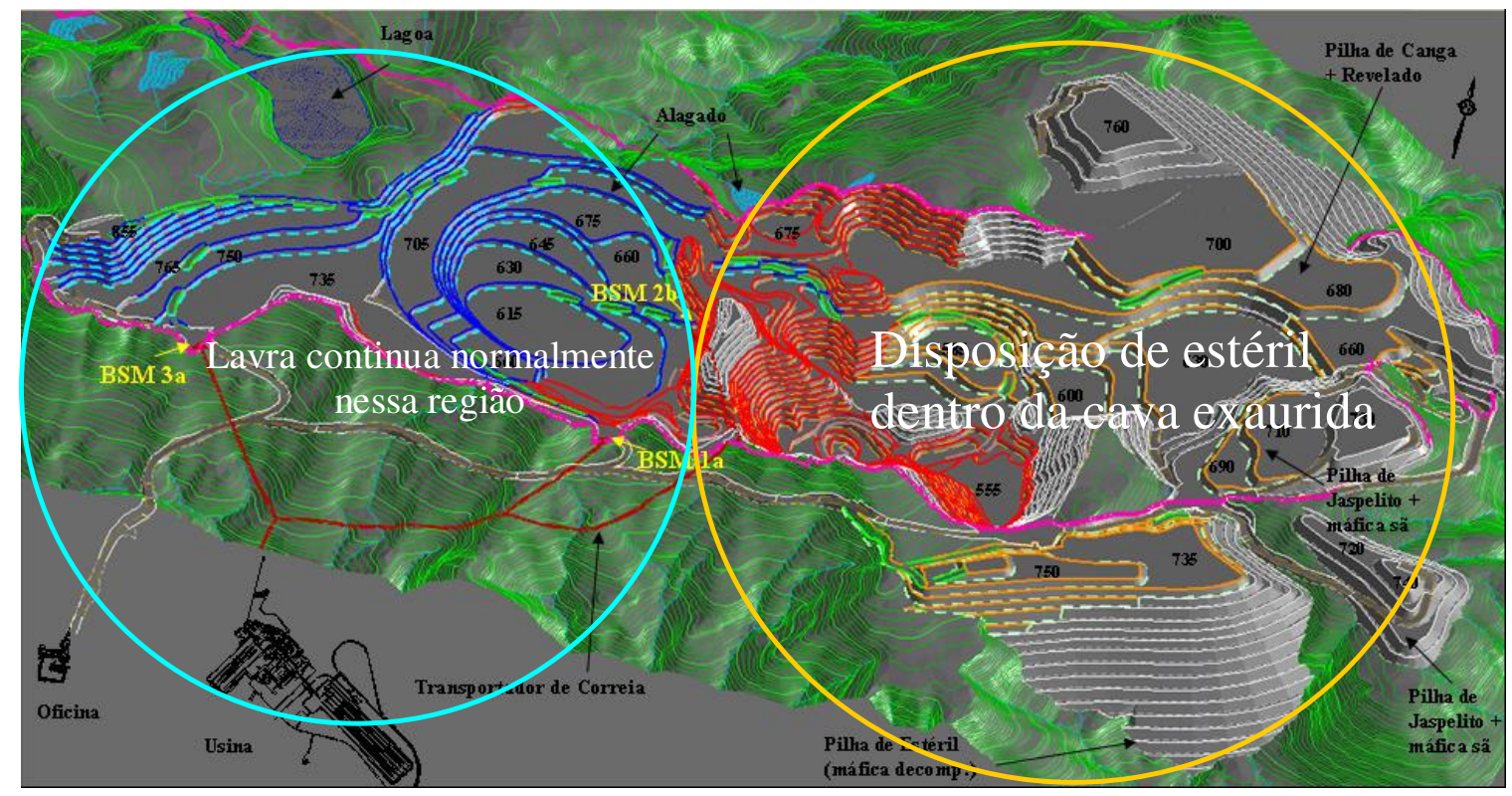

Figura 31 - Croqui sem escala ano 20 (2030) lavra concomitante com a disposição de estéril dentro da mina

Fonte - Relatório Serra Sul Fel 3 - Relatório interno Vale, Mar/2008

Esse método de disposição, tipicamente, dispõe o material estéril dentro de uma cava exaurida de uma mina e dispensa a construção de diques e drenos de fundo (Ritcey, 1989). Pela afirmação acima pode-se concluir que fica facilitada a disposição do estéril nessa condição, pois dispensa a construção de dreno pela inexistência de água perene no fundo da cava como ocorre no caso de vales utilizados para esse fim, que podem apresentar pequenas nascentes ou águas que fluem durante um certo período como, por exemplo, as águas armazenadas na época das chuvas pela canga ferrífera de cobertura.

Outra vantagem da disposição do estéril em cava é a não necessidade de um sistema de drenagem interno e superficial, pois, o sistema de drenagem superficial precisa ser constituído por canais de drenagem periférica ao longo dos contatos da pilha com o terreno natural, descidas de água em degraus de gabião para descarte logo a jusante do pé da pilha, onde são implantadas bacias de dissipação para a redução do potencial erosivo do fluxo hidráulico, e isso acarreta custos adicionais para a empresa. 
Essa metodologia também descarta o plano de monitoramento da pilha que prevê a verificação visual, ou seja, inspeção local da pilha e estruturas acessórias (dique de contenção, estruturas hidráulicas etc.) e a utilização de instrumentos, tais como:

-Medidores de nível d'água: determinação do nível de água no maciço da pilha; -Medidores de vazão afluente a jusante do pé da pilha: determinação das vazões afluentes ao dreno de fundo;

-Marcos topográfico: verificação de eventuais deformações na estrutura do maciço da pilha. 


\section{RESULTADOS}

Quanto ao aspecto ambiental, tem-se uma característica muito apreciada ambientalmente, pois se evita a necessidade de degradação de áreas para a disposição de estéril, confinando na cava esse material gerado.

A indústria de minério de ferro é responsável por parte considerável do superávit comercial do país, a Vale, maior produtora mundial de minério de ferro, é a empresa responsável individualmente pelo maior superávit líquido (diferença entre exportações e importações da corporação) do País, portanto, uma melhoria nas suas operações implicaria em aumento deste mesmo superávit.

A título de ilustração, segundo o Relatório Anual da Vale de 2004, o EBITDA (ganhos antes de imposto de renda, amortizações e depreciações) gerado pela área de ferrosos da empresa (minério de ferro, pelotas, manganês e ferro-liga) em 2003 foi de 5,36 bilhões de Reais, com uma margem de $46,1 \%$, o que mostra que mesmo com pequenos benefícios percentuais as quantias em valores absolutos podem ser significativas.

Como descrito na introdução, tem-se os seguintes ganhos tangíveis e intangíveis:

- Reabilitação mais fácil da área degradada da mina;

- Diminuição considerável da área degradada na Flonaca, com redução significativa dos impactos ambientais na região;

- Disposição do estéril removido de uma mina próxima, ou de um outro setor da mesma mina, na cava da mina exaurida, ou em parte dela, com redução significativa das DMT'S (Distância Média de Transporte) e, conseqüentemente, com aumento da produtividade;

- Não degradação de uma área virgem com a colocação de estéril, quase sempre em vales com densa vegetação e nascentes, com isso, menores custos de descomissionamento;

- Possibilidade de melhor relacionamento com os órgãos ambientais;

- Pode ser considerada uma atividade de reabilitação da área degradada. 
- Dispensa a construção de diques e drenos de fundo, obras bastante caras;

- Como o material estéril depositado ficará confinado entre as paredes da mina não há risco de ruptura dos taludes.

\subsection{QUANTITATIVO DA REDUÇÃO EM HECTARES DA ÁREA DEGRADADA}

A partir do Ano 07 (2017) a geometria da cava permite a disposição do estéril dentro da mina. Isso possibilita a redução no desmatamento da região. Segue abaixo os cálculos realizados para a obtenção desse quantitativo.

Foi calculada a area da geometria até o ano 20 (2030) para disposição de estéril somente da região na qual o estéril foi depositado dentro da cava até esse ano. A Figura 32 e 33 mostra a área calculada.

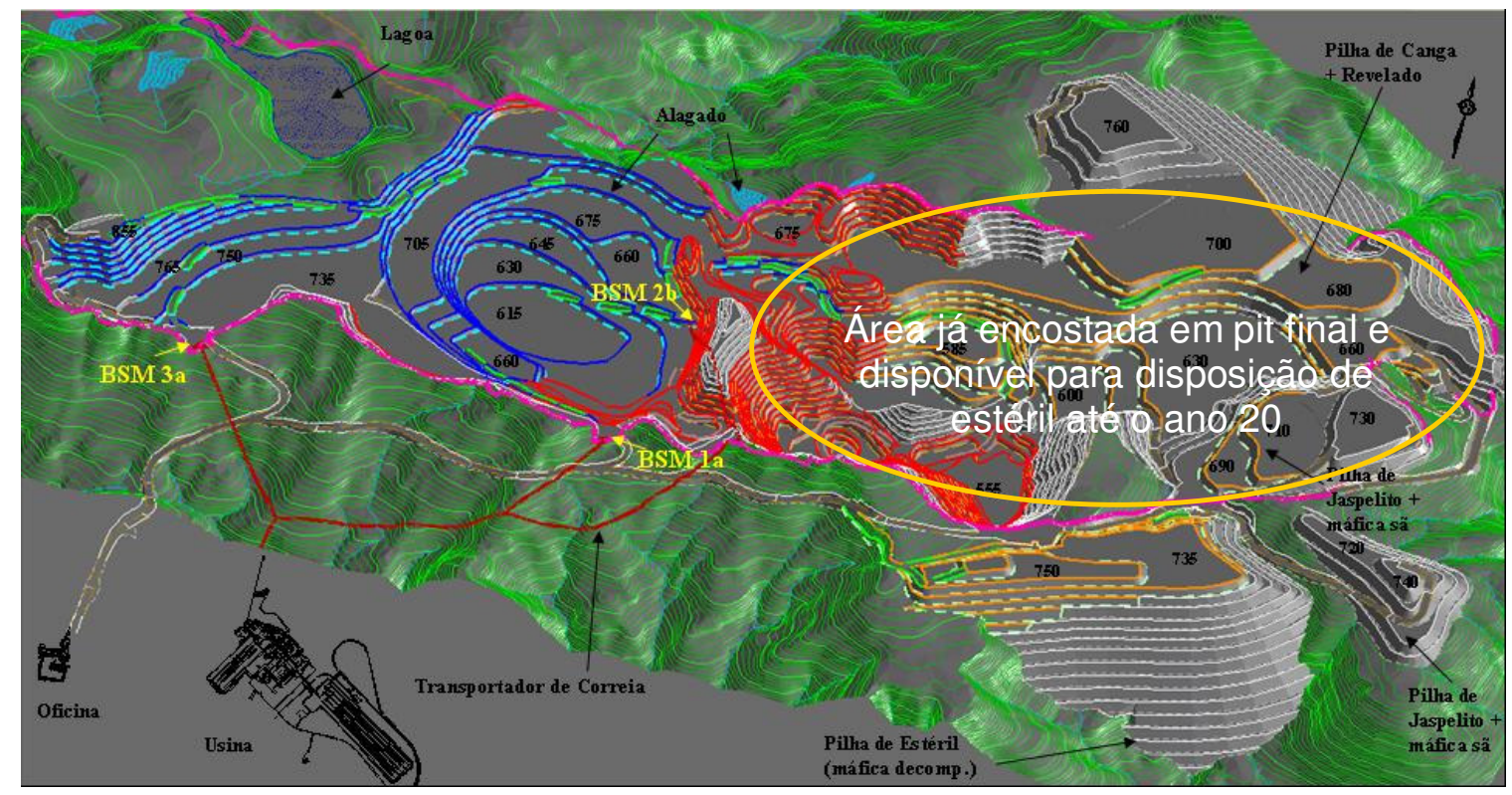

Figura 32 - Croqui sem escala da área calculada em hectares para disposição de estéril Fonte - Relatório Serra Sul Fel 3 - Relatório interno Vale, Mar/2008 


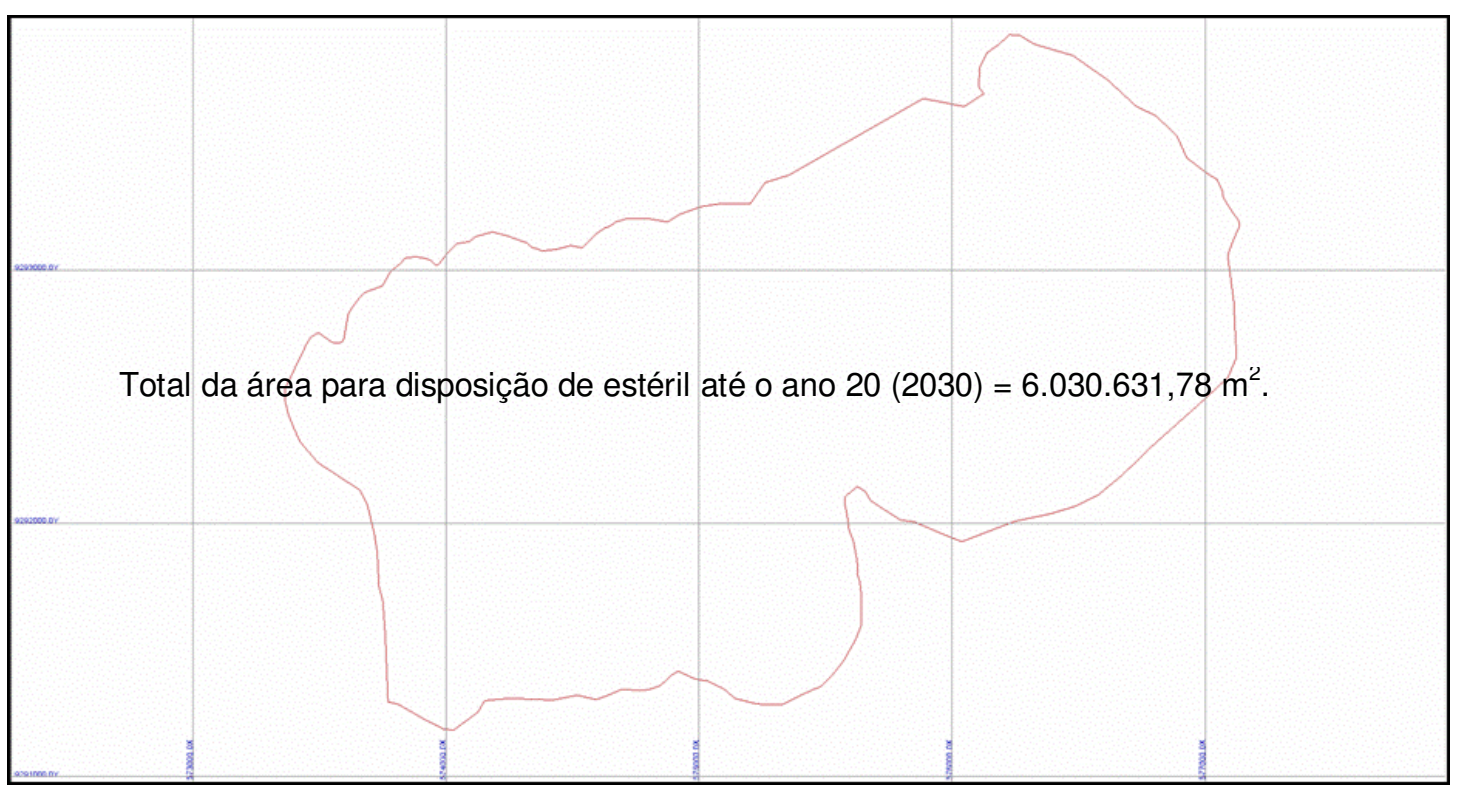

Figura 33 - Croqui sem escala do polígono da área calculado para dispor estéril dentro da cava Fonte - Carvalho e De Tomi, 2009

Total da área para disposição de estéril até o ano $20(2030)=6.030 .631,78 \mathrm{~m}^{2}$.

$1 \mathrm{Ha}=10000 \mathrm{~m}^{2}$

$6.030 .631,78 \mathrm{~m}^{2}=603,06 \mathrm{Ha}$

Portanto, há uma estimativa de redução inicial de 603,06 Hectares de

desmatamento, com diminuições futuras maiores, pois, a geometria considerando a disposição de estéril dentro da cava foi projetada somente até o ano 20 (2030). 


\section{CONCLUSÕES}

Pelo exposto nos resultados descritos e realizados anteriormente, a metodologia sugerida, sendo realizada como rotina em outras minas com contexto operacional similar ao da mina do estudo de caso, levará a ganhos significativos, quais sejam: ambientais, evitando a degradação de grandes áreas para disposição de estéril; e econômicos, devido à redução das distâncias de transportes e também a redução progressiva do passivo ambiental, componente chave no fechamento de mina.

As contribuições específicas da presente pesquisa incluem:

1. Análise da disposição de estéril dentro do contexto de seqüenciamento de lavra, permitindo o aperfeiçoamento do processo de reabilitação de áreas degradas na mina;

2. Gerenciamento da disposição do estéril dentro da cava, diminuindo a área degradada nos entornos da operação, com redução significativa dos impactos ambientais na região, redução inicial em torno de 603,06 hectares de desmatamento, conforme descrito no Capítulo 5.

\subsection{RECOMENDAÇÕES DE CONTINUIDADE DO TEMA DE PESQUISA}

1. Estudo da metodologia da atual dissertação associada ao método de corte e enchimento (Lage, 2001) para quantificar de forma objetiva o ganho de reserva antes de dispor o estéril na cava;

2. Pesquisa de desenvolvimento de um simulador de lavra, para simular a execução do planejamento, e compará-lo com outras alternativas de disposição;

3. Estudo de identificação de KPls ambientais associadas ao seqüenciamento de lavra para avaliar objetivamente as vantagens ambientais e econômicas da 
presente metodologia sobre as metodologias tradicioais orientadas à maximização econômica da lavra;

4. Desenvolvimento de um algoritmo para automatizar a presente metodologia, e torná-la uma opção incorporada às técnicas tradicionais de seqüenciamento, possibilitando que os planejadores de lavra possam estudar também alternativas de seqüenciamento que minimiza o impacto ambiental ao mesmo tempo em que maximiza o valor econômico do empreendimento. 


\section{REFERÊNCIAS BIBLIOGRÁFICAS}

ASSOCIAÇÃO BRASILEIRA DE NORMAS TÉCNICAS. NBR 13029: coletânea de normas de mineração e meio ambiente: ed. gráfica polar Itda. Rio de Janeiro, 1993. $58 \mathrm{p}$.

ASSOCIAÇÃO BRASILEIRA DE NORMAS TÉCNICAS. NBR 13029: elaboração e apresentação de projeto de disposição de estéril em pilha. Rio de Janeiro, 2006. 5 p. Disponível em: <http://www.abnt.org.br.. . Acesso em: 02 fev. 2009.

Apostila sobre formação de depósito de estéril e rejeito - Relatório interno Vale $-2000$.

Avaliação de Recursos de Minério de Ferro Jazida de Serra Sul - Alvo S11 Corpos C e D - Relatório interno Vale - Setembro, 2008.

BONGARÇON, D. F.; GUIBAL, D. Parameterization of Optimal Designs of an Open Pit - Beggining of a New Phase of Research. Trans, SME, AIME, Vol. 274, 1984, p. 1801-1805.

BONGARÇON, D. F. Myth and reality: a status report on computer open pit optimization algorithms in the 90's. Disponível em :

$<$ http://pws.prserv.net/Goodsampling.com/4D.pdf,1993.>. Acesso em: 15 jan. 2005.

Carajás Update - Relatório interno Vale - 2006.

CARVALHO, M. G. A; DE TOMI, G. Estratégia Ambiental Pró-ativa:

Seqüenciamento de Lavra concomitante com a disposição de estéril dentro da mina. Artigo submetido à Revista REM, 2009.

COLEOU, T. Technical Parameterization of Reserves for Open Pit Design and MinePlanning. Proc, 21st APCOM, 1988. p. 485-494.

CHAUSSON, D. S.; DE TOMI, G.; AZEVEDO, R. C. Otimização do Seqüenciamento de Lavra. Brasil Mineral, Sao Paulo: v. 190, 2001, p. 30-33.

FERREIRA, M. F.; DE TOMI G. Optimizing ultimate open pit limits with quality constraints; Proceedings of APCOM'2001, Beijing, China, April 25-27, 2001. 
GATZWEILER, R. Cover Designe for radioactive and AMD-producing Mine Waste in the Ronneburg area, Eastern Thuringia, Waste Management, Alemanha, no 21 , p. $175-184.2001$.

GERSHON, M. E. A Linear Programming Approach to Mine Schedulling Optimizacion, Proc, 17th APCOM. , 1982, p. 483 - 493.

GIRODO, A. C.; CAMPOS, A. C. A., VALENTE, J. Otimização de Cavas ou Estacionarização de Parâmetros: Qual o Caminho a Seguir?. 2000.

HIGGINS, R. J. Environmental Management of New Mining Operations, In: Salomoms W \& Förstner.U. , Environments Management of Solid Waste, Springer-Verlag ed., NY, USA, 1988. $396 \mathrm{p}$.

KENNEDY, B. A. Surface Mining, 2nd Edition. Society for Mining, Metallurgy and Exploration, Inc. Littleton, CO, USA, 1990. p. 770-776.

KENTWELL, D. MineMAX Planner vs Whittle Four-X n Open Pit Otimisation Software Evaluation and Comparison; SRK Consulting, Brisbane Australia ;. Disponível em: <http://www.minemax.com/products/planner/MMPvsFourX.pdf,2002.> Acesso em: 18 out. 2004.

KUYUCAK, N. Acid Mine Drainage, Mining Environmental Management, p. 12-15, Canadá. 2001.

LAGE, E. R. Corte e enchimento na cava da mina de Alegria. 2001. Dissertação (Mestrado). Universidade Federal de Ouro Preto.

LERCHS, H.; GROSSMAN, L. Optimum Design of Open-Pit Mines. Trans. C.I. M Vol. LXVIII, 1965, p. 17- 24.

MATHERON, G. (1975a). Le Parametrage des Contours Optimaux, C.G.M.M., Fontainebleau, France, 1975.

MATHERON, G. (1975b). Le Parametrage Tecnhique dês Reserves, C.G.M.M., Fontainebleau, France, 1975. 
OLIVEIRA, J. B. Desativação de Empreendimentos Mineiros: Estratégias para diminuição do passivo ambiental. 2001. Tese (doutorado), Escola Politécnica da Universidade de São Paulo.

Relatório Anual 2003 - Vale. Disponível em:

$<$ http://www.cvrd.com.br/br extrafiles/infofin/ra2003/index.asp $>$. Acesso em: 10 jan. 2004.

Relatório Técnico Planejamento de Lavra - Projeto Serra Sul - Fel 3 - Relatório interno Vale - Março/2008.

Relatório Programa 130 Mta, Relatório interno Vale, 2007.

Relatório da Diretoria de Desenvolvimento de Projetos Minerais (DIPM) Relatório interno Vale - Jul/2007

RITCEY, G. M. Tailings Management, Problems and Solutions in the Mining Industry,Elsevier Sc. Pub. B.V, NY, USA. 1989. 970 p.

RIPLEY, E. A.; REDMAN, R. E.; CROWDER, A. A. Environmental Effects of Mining, St.Lucie Press, Florida. USA. 1996. 356 p.

SILVA, A. P. Metodologia para Determinação de Cava Final e Seqüenciamento de Lavra para a Mina de N5 Sul, Monografia MBA em Mineração, Programa de Educação Continuada em Engenharia USP e Vale, São Paulo, 2003.

WANG, Q.; SEVIM, H. Enhanced Production Planning in Open Pit Mining Through Intelligent Dynamic Search", Proc, 23rd APCOM, 1992. 461-471 p.

WRIGHT, E. A. Open Pit Mine Design Models, Alemanha, trans tech publications, 1990, V 1.

WHITTLE, J. The Facts and Fallacies of Open-Pit Design, Whittle Programming Pty Ltd, 1989.

YAMATOMI, J.; MOGI, G.; AKAIKE, A.; YAMAGUCHI, U. Selective Extraction Dynamic Cone Algorithm for Three-Dimensional Open Pit Desings, Technical Proc, APCOM XXV 1995, 1995. 


\section{ANEXO}




\section{ANEXO 01 - Aplicação Método dos Cones Flutuantes}

O conceito da técnica dos cones flutuantes é muito simples, sendo neste exemplo utilizada uma seção vertical de um modelo econômico de blocos (Figura 34), contendo o valor de cada bloco, com 5 linhas e 10 colunas $(5,10)$.

\begin{tabular}{|c|c|c|c|c|c|c|c|c|c|c|}
\hline & 1 & 2 & 3 & 4 & 5 & 6 & 7 & 8 & 9 & 10 \\
\hline 1 & -2 & -1 & -2 & 3 & -3 & -1 & -3 & -2 & -2 & -2 \\
\hline 2 & -2 & 1 & -2 & 7 & -2 & -3 & -2 & 2 & -3 & -1 \\
\hline 3 & -1 & -2 & 2 & 8 & 5 & -3 & 5 & -3 & -2 & -1 \\
\hline 4 & -4 & -3 & 2 & -3 & 0 & -3 & 2 & -1 & -3 & -2 \\
\hline 5 & -5 & -4 & -1 & 4 & 8 & -2 & -2 & -2 & -1 & -1 \\
\hline
\end{tabular}

Figura 34 - Seção com blocos do modelo econômico Fonte - Silva, 2003

Inicia-se a simulação da lavra na linha 1. O primeiro bloco positivo encontrado tem valor $3(1,4)$, não ocorrendo nenhum bloco acima dele. O bloco será lavrado e a nova configuração é representada na Figura 35, e o valor acumulado da cava é de 3.

\begin{tabular}{|c|c|c|c|c|c|c|c|c|c|c|}
\hline & 1 & 2 & 3 & 4 & 5 & 6 & 7 & 8 & 9 & 10 \\
\hline 1 & -2 & -1 & -2 & $\times$ & -3 & -1 & -3 & -2 & -2 & -2 \\
\hline 2 & -2 & 1 & -2 & 7 & -2 & -3 & -2 & 2 & -3 & -1 \\
\hline 3 & -1 & -2 & 2 & 8 & 5 & -3 & 5 & -3 & -2 & -1 \\
\hline 4 & -4 & -3 & 2 & -3 & 0 & -3 & 2 & -1 & -3 & -2 \\
\hline 5 & -5 & -4 & -1 & 4 & 8 & -2 & -2 & -2 & -1 & -1 \\
\hline
\end{tabular}

Figura 35 - Lavra do bloco $(1,4)$ Fonte - Silva, 2003 
Não existindo mais blocos positivos na linha 1, segue-se para a linha 2. O primeiro bloco positivo é de valor $1(2,2)$. A precedência de lavra determina que para lavrar este bloco é necessária a lavra dos blocos $(1,1),(1,2)$ e $(1,3)$. A somatória dos valores destes blocos é de -5 , tornando inviável a lavra do bloco $(2,2)$. Seguindo na linha 2, o próximo bloco positivo $(2,4)$ tem valor 7 . A precedência dos blocos determina a lavra dos blocos $(1,3)$ e $(1,5)$, sendo que o bloco $(1,4)$ já tendo sido lavrado não será incluído. O valor total dos blocos é de 2, sendo viável a lavra. A nova configuração é apresentada na Figura 36 e a cava total parcial apresenta valor de 5 .

\begin{tabular}{|c|c|c|c|c|c|c|c|c|c|c|}
\hline & 1 & 2 & 3 & 4 & 5 & 6 & 7 & 8 & 9 & 10 \\
\hline 1 & -2 & -1 & & & & -1 & -3 & -2 & -2 & -2 \\
\hline 2 & -2 & 1 & -2 & & -2 & -3 & -2 & 2 & -3 & -1 \\
\hline 3 & -1 & -2 & 2 & 8 & 5 & -3 & 5 & -3 & -2 & -1 \\
\hline 4 & -4 & -3 & 2 & -3 & 0 & -3 & 2 & -1 & -3 & -2 \\
\hline 5 & -5 & -4 & -1 & 4 & 8 & -2 & -2 & -2 & -1 & -1 \\
\hline
\end{tabular}

Figura 36 - Lavra do bloco $(2,4)$ Fonte - Silva, 2003

$\mathrm{Na}$ linha 2 o valor positivo $2(2,8)$ é inviável por apresentar blocos precedentes negativos de -7 .

$\mathrm{Na}$ terceira linha o bloco $(3,3)$ de valor 2 é inviável, pois deste bloco mais a dos blocos $(1,1),(1,2),(2,2)$ e $(2,3)$ determinam um valor total de -2 . O bloco de valor 8 $(3,4)$ será lavrado, pois os blocos precedentes apresentam somatória negativa de 6 , permitindo um saldo de 2. A nova geometria tem valor total de +7 , sendo representada na Figura 37. 


\begin{tabular}{|c|c|c|c|c|c|c|c|c|c|c|}
\hline & 1 & 2 & 3 & 4 & 5 & 6 & 7 & 8 & 9 & 10 \\
\hline 1 & -2 & & & & & & -3 & -2 & -2 & -2 \\
\hline 2 & -2 & 1 & & & & -3 & -2 & 2 & -3 & -1 \\
\hline 3 & -1 & -2 & 2 & & 5 & -3 & 5 & -3 & -2 & -1 \\
\hline 4 & -4 & -3 & 2 & -3 & 0 & -3 & 2 & -1 & -3 & -2 \\
\hline 5 & -5 & -4 & -1 & 4 & 8 & -2 & -2 & -2 & -1 & -1 \\
\hline
\end{tabular}

Figura 37 - Lavra do bloco $(3,4)$

Fonte - Silva, 2003

A lavra dos blocos $(3,5)$ e $(3,7)$ são inviáveis, pois seus cones de extração tem valor -1 e -3. Neste ponto é importante salientar a necessidade de que a cada atualização da geometria, ocorra um retorno da análise dos blocos positivos anteriormente não viáveis. Caso isto não seja feito, o bloco $(3,3)$ que foi definido como inviável na primeira passagem de sua linha, continuará sendo indicado como inviável, quando na verdade, após a lavra do bloco $(3,4)$, passou a ser viável. A nova geometria passa a ser a da Figura 38, com a cava apresentando valor total de 8.

\begin{tabular}{|l|l|l|l|l|l|l|l|l|l|l|}
\hline & 1 & 2 & 3 & 4 & 5 & 6 & 7 & 8 & 9 & 10 \\
\hline 1 & & &
\end{tabular}

Figura 38 - Lavra do bloco $(3,3)$ Fonte - Silva, 2003 
A simulação dos cones dos blocos positivos que restaram apresentam inviabilidade. Bloco $(4,3)$ com valor $-1,(4,7)$ com valor -14 , $(5,4)$ com valor -4 e bloco $(5,5)$, com valor -1 , determinando a cava final com valor 8 .

Ocorre que uma das imperfeições do método está ligada à combinação de blocos. $\mathrm{Na}$ linha 5 temos dois blocos adjacentes, $(5,4)$ e $(5,5)$ que não apresentaram viabilidade individualmente, mas a combinação destes dois blocos indicam um cone positivo de 1, devendo ser incluídos na representação da cava final, gerando um valor total de 9 .

A cava final real é apresentada na Figura 39.

\begin{tabular}{|c|c|c|c|c|c|c|c|c|c|c|}
\hline & 1 & 2 & 3 & 4 & 5 & 6 & 7 & 8 & 9 & 10 \\
\hline 1 & -2 & -1 & -2 & 3 & -3 & -1 & -3 & -2 & -2 & -2 \\
\hline 2 & -2 & 1 & -2 & 7 & -2 & -3 & -2 & 2 & -3 & -1 \\
\hline 3 & -1 & -2 & 2 & $\left(\begin{array}{c}\text { Valor } \\
-4\end{array}\right.$ & -3 & 5 & -3 & -2 & -1 \\
\hline 4 & -4 & -3 & 2 & $-\sqrt{-9}$ & -3 & 2 & -1 & -3 & -2 \\
\hline 5 & -5 & -4 & -1 & 4 & 8 & -2 & -2 & -2 & -1 & -1 \\
\hline
\end{tabular}

Figura 39 - Configuração Cava Final - Cones Flutuantes Fonte - Silva, 2003 


\section{ANEXO 02 - Aplicação do Algoritmo de Lerchs-Grossmann por Programação Dinâmica em Duas Dimensões}

Sobre o mesmo modelo de blocos do anexo 01 será realizada a exemplificação da determinação do contorno de cava final para a seção.

Inicialmente deverá ser realizada a acumulação dos valores das colunas e inserida uma linha com blocos de valor 0 antes do primeiro nível (Figura 40).

A fórmula de acumulação dos valores dos blocos é:

$$
\begin{gathered}
M i j=\sum m k j \\
K=1
\end{gathered}
$$

Onde Mij é o valor econômico da extração dos blocos da coluna, sendo o bloco (i, j) a base do cone e mkj é o valor do bloco $(k, j)$.

\begin{tabular}{|c|c|c|c|c|c|c|c|c|c|c|c|}
\hline & & 1 & 2 & 3 & 4 & 5 & 6 & 7 & 8 & 9 & 10 \\
\hline 0 & 0 & 0 & 0 & 0 & 0 & 0 & 0 & 0 & 0 & 0 & 0 \\
\hline 1 & - & -2 & -1 & -2 & 3 & -3 & -1 & -3 & -2 & -2 & -2 \\
\hline 2 & - & -4 & 0 & -4 & 10 & -5 & -4 & -5 & 0 & -5 & -3 \\
\hline 3 & - & -5 & -2 & -2 & 18 & 0 & -7 & 0 & -3 & -7 & -4 \\
\hline 4 & - & -9 & -5 & 0 & 15 & 0 & -10 & 2 & -4 & -10 & -6 \\
\hline 5 & - & -14 & -9 & -1 & 19 & 8 & -12 & 0 & -6 & -11 & -7 \\
\hline
\end{tabular}

Figura 40 - Acumulação dos valores econômicos dos blocos Fonte - Silva, 2003

O próximo passo do procedimento será a comparação entre os valores adjacentes à esquerda de cada bloco e a soma do maior valor ao do bloco analisado. Este novo 
valor do bloco é atualizado no modelo e passa-se ao bloco seguinte. Este procedimento é realizado na coluna, iniciando da coluna 1.

A fórmula que descreve este procedimento é:

$\mathrm{Pij}=$ Mij + Máximo $((\mathrm{Pi}-1, \mathrm{j}-1),(\mathrm{Pi}, \mathrm{j}-1),(\mathrm{Pi}+1, \mathrm{j}-1))$

Onde Pij é o novo valor do bloco (i,j), Mij é o valor do bloco analisado e Máximo((Pi $1, j-1),(P i, j-1),(P i+1, j-1))$ é o maior valor entre os blocos adjacentes á esquerda do bloco analisado.

Após análise do bloco é colocada uma seta ligando o bloco analisado ao bloco de maior valor.

Exemplificando (figura 26):

Para o bloco $(2,5)$, de valor -5 , teríamos os blocos adjacentes $(1,4),(2,4)$ e $(3,4)$. $O$ maior valor dentre estes blocos é 18 , do bloco $(3,4)$. O novo valor $P$ do bloco $(2,5)$ será 13.

\begin{tabular}{|c|c|c|}
\hline & 4 & 5 \\
\hline 1 & 3 & \\
\hline 2 & 10 & -5 \\
\hline 3 & 18 & \\
\hline
\end{tabular}

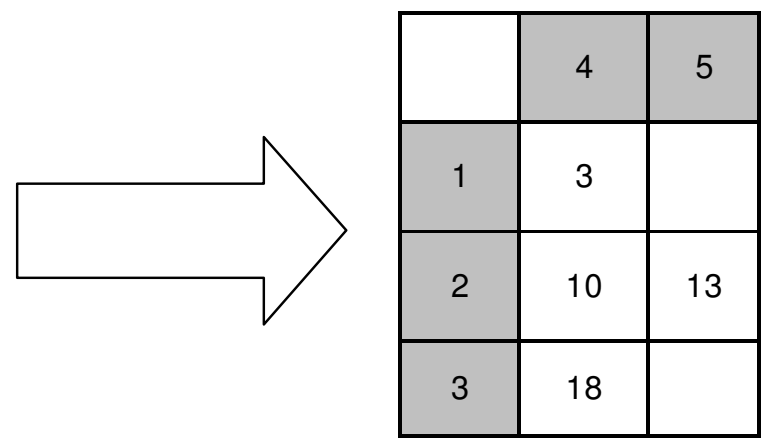

Figura 41 - Análise dos blocos adjacentes Fonte - Silva, 2003

A aplicação deste procedimento ao modelo acumulado da Figura 41 é apresentada na Figura 42. 


\begin{tabular}{|c|c|c|c|c|c|c|c|c|c|c|c|}
\hline & & 1 & 2 & 3 & 4 & 5 & 6 & 7 & 8 & 9 & 10 \\
\hline 0 & 0 & 0 & 0 & 0 & 0 & 0 & 0 & 0 & 0 & 0 & 0 \\
\hline 1 & - & -2 & -1 & -2 & 3 & 5 & 8 & 7 & 5 & 9 & 7 \\
\hline 2 & - & -4 & -2 & -5 & 8 & 9 & 10 & 5 & 1 & 6 & 6 \\
\hline 3 & - & -5 & -6 & -4 & 14 & -14 & 7 & 11 & 10 & 4 & 2 \\
\hline 4 & - & -9 & -10 & -6 & 11 & 14 & 11 & -13 & 9 & 0 & -2 \\
\hline 5 & - & -14 & -18 & -11 & 13 & 21 & 9 & 11 & 7 & -2 & \\
\hline
\end{tabular}

Figura 42 - Análise final Fonte - Silva, 2003

O limite da cava na seção será definido acompanhando o fluxo das setas a partir do bloco $(0,10)$. A Figura 28 apresenta este fluxo.

\begin{tabular}{|c|c|c|c|c|c|c|c|c|c|c|c|}
\hline & & 1 & 2 & 3 & 4 & 5 & 6 & 7 & 8 & 9 & 10 \\
\hline 0 & 0 & 0 & 0 & 0 & 0 & 0 & 0 & 0 & 0 & 0 & 0 \\
\hline 1 & - & -2 & -1 & -2 & 3 & 5 & 8 & 7 & 5 & 9 & 7 \\
\hline 2 & - & -4 & -2 & -5 & 8 & 9 & 10 & 5 & 11 & 6 & 6 \\
\hline 3 & - & -5 & -6 & -4 & 14 & 14 & 7 & 11 & 10 & 4 & 2 \\
\hline 4 & - & -9 & -10 & -6 & 11 & 14 & 11 & 13 & 9 & 0 & -2 \\
\hline 5 & - & -14 & -18 & -11 & 413 & 21 & 9 & 11 & 7 & -2 & \\
\hline
\end{tabular}

Figura 43 - Configuração da cava final - Lerchs Grossmann Fonte - Silva, 2003

Estes limites são os mesmos definidos no Anexo 01. 
ANEXO 03 


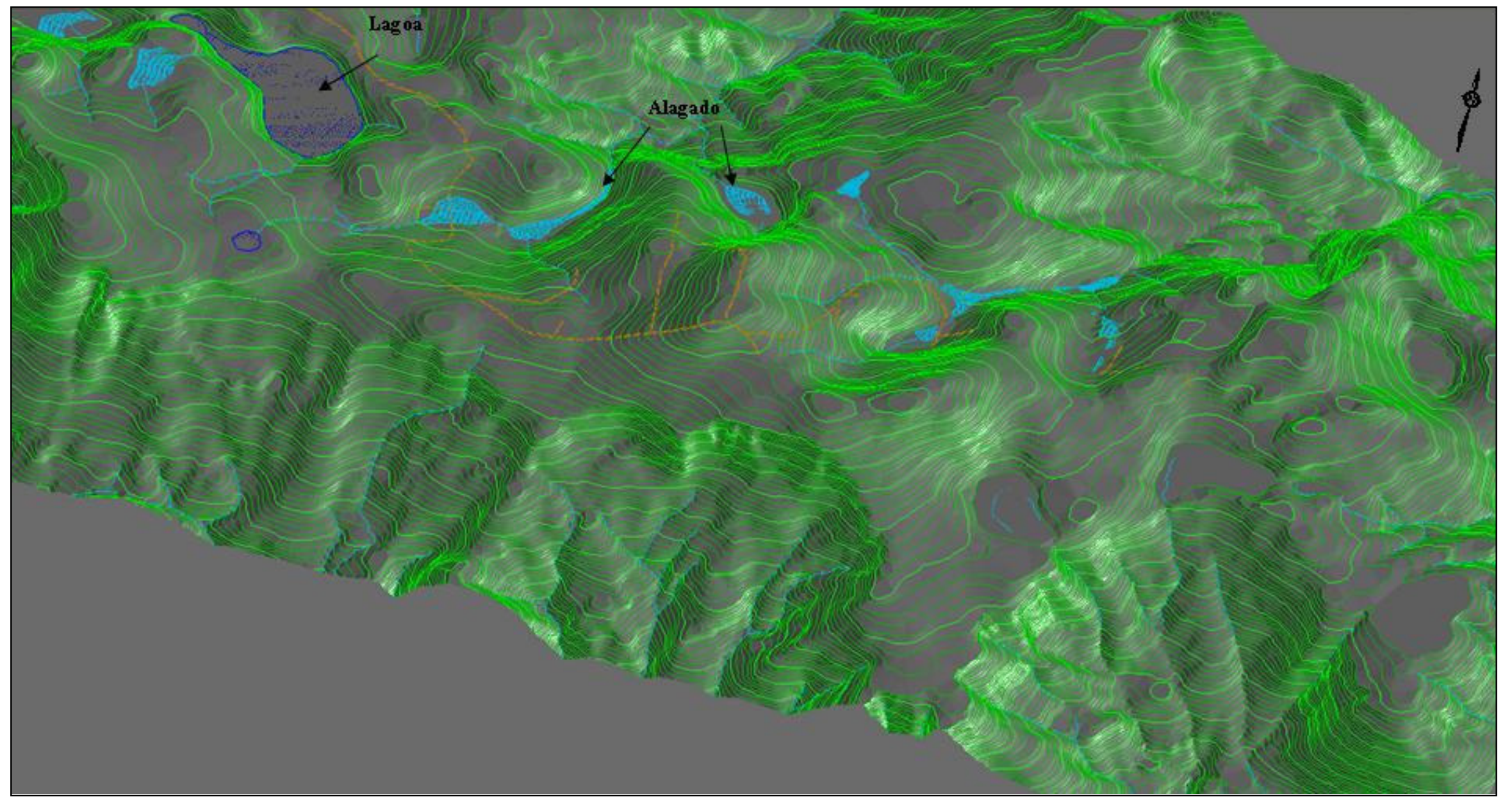

Figura 44 - Croqui sem escala da topo primitiva

Fonte - Relatório Serra Sul Fel 3 - Relatório interno Vale, Mar/2008 


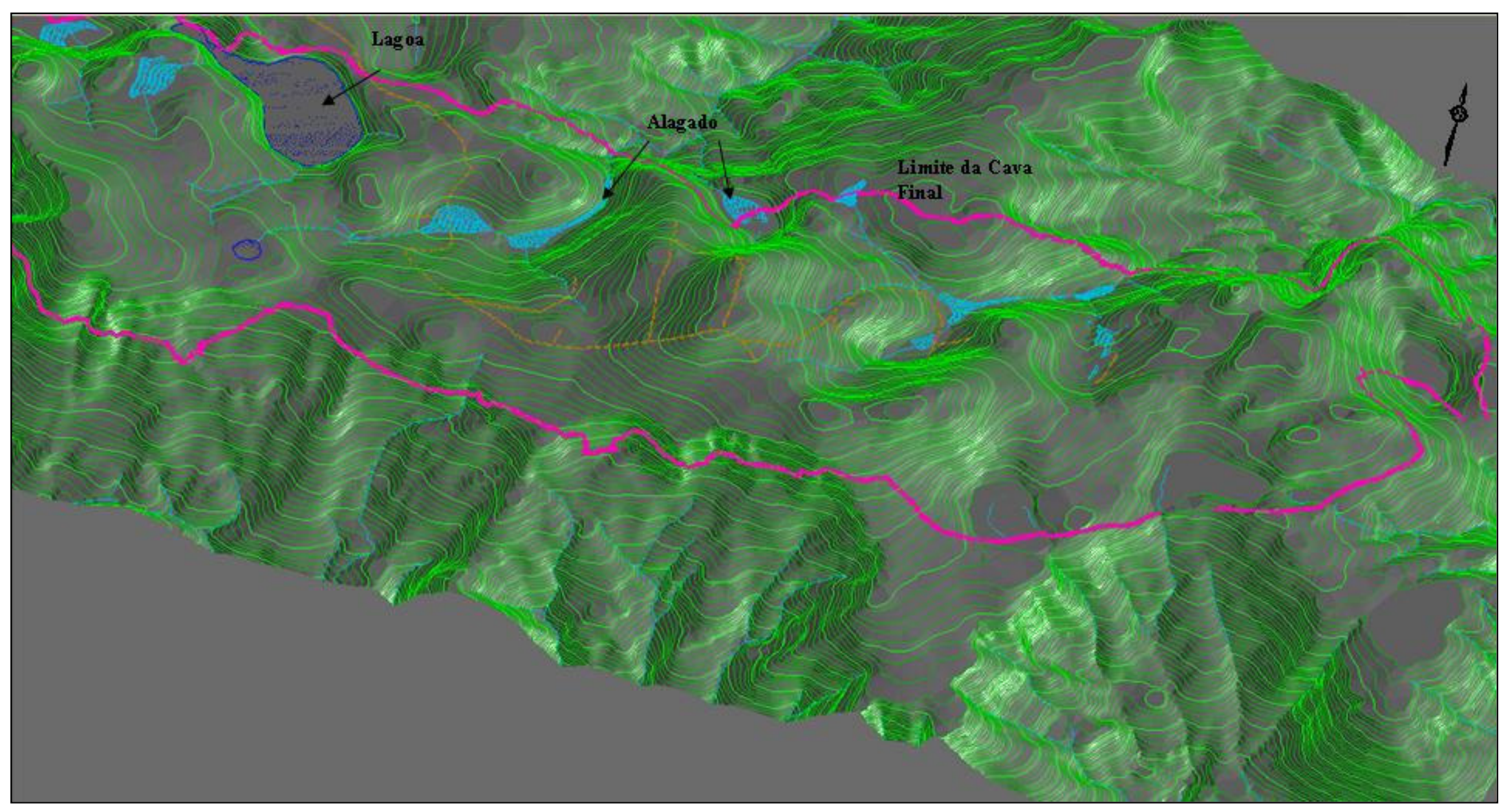

Figura 45 - Croqui sem escala da topo primitiva com limite da cava Fonte - Relatório Serra Sul Fel 3 - Relatório interno Vale, Mar/2008 


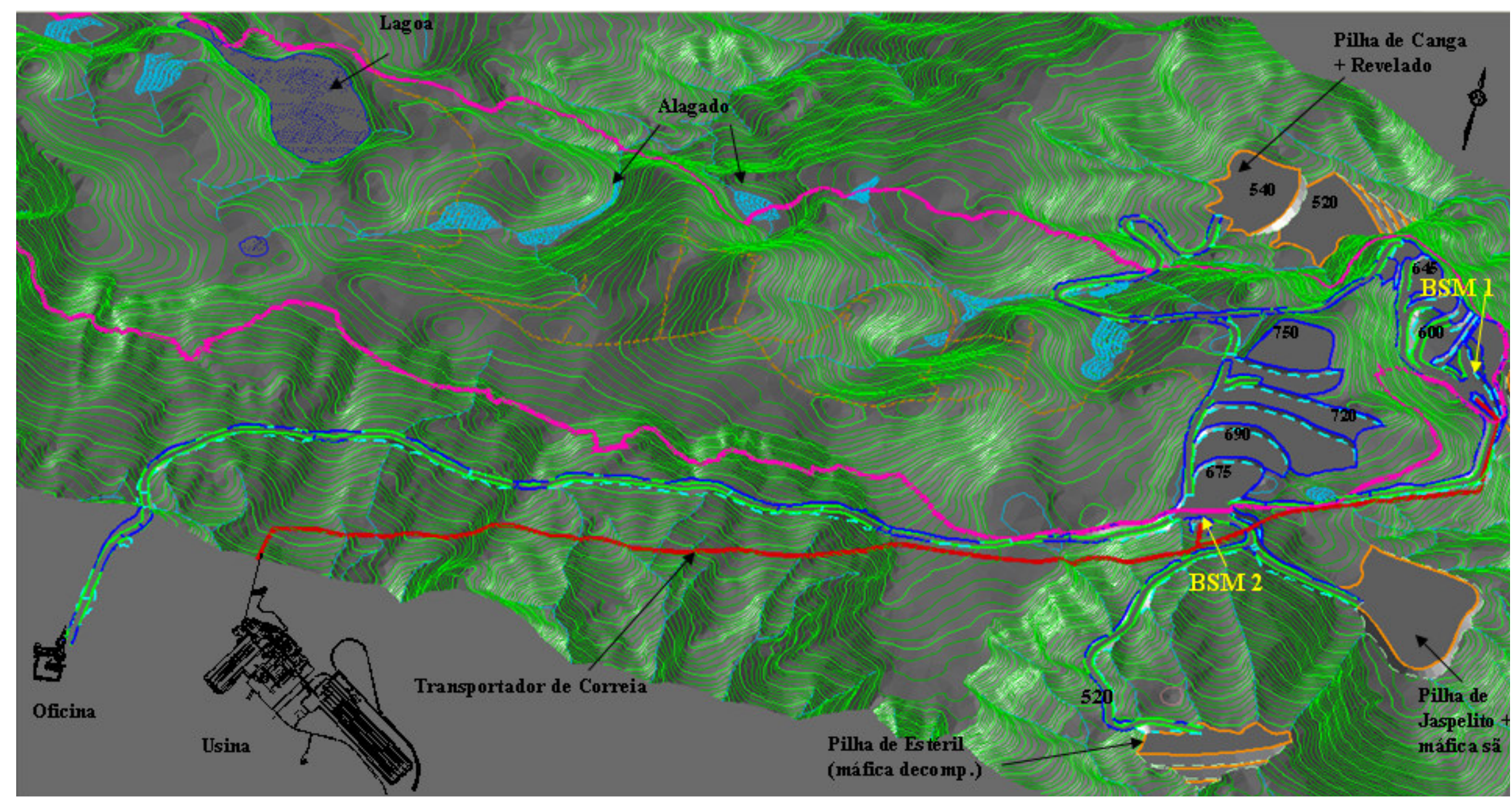

Figura 46 - Croqui sem escala do plano de preparação da lavra Fonte - Relatório Serra Sul Fel 3 - Relatório interno Vale, Mar/2008 


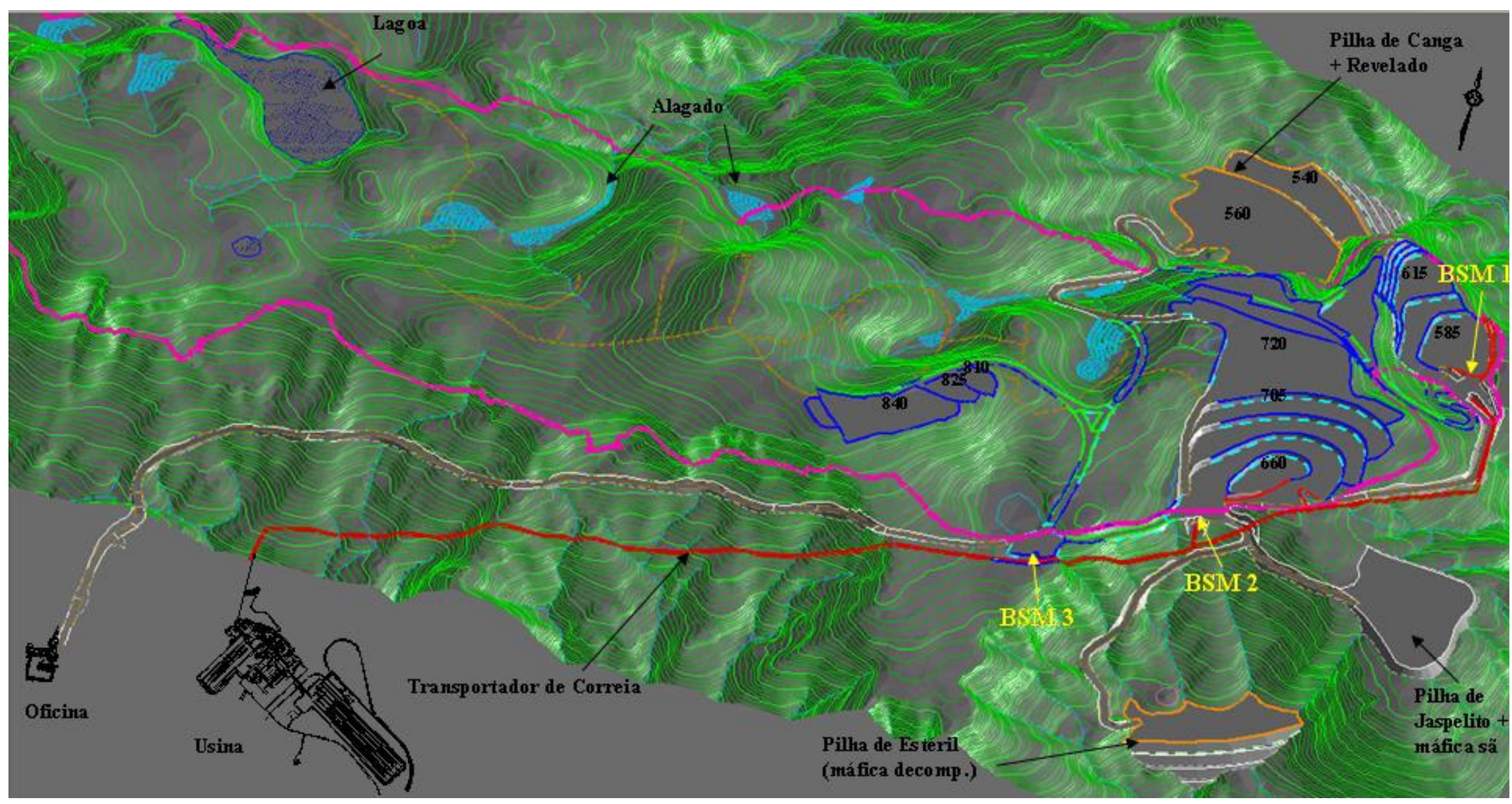

Figura 47 - Croqui sem escala do plano de lavra ano 01 (2011) Fonte - Relatório Serra Sul Fel 3 - Relatório interno Vale, Mar/2008 


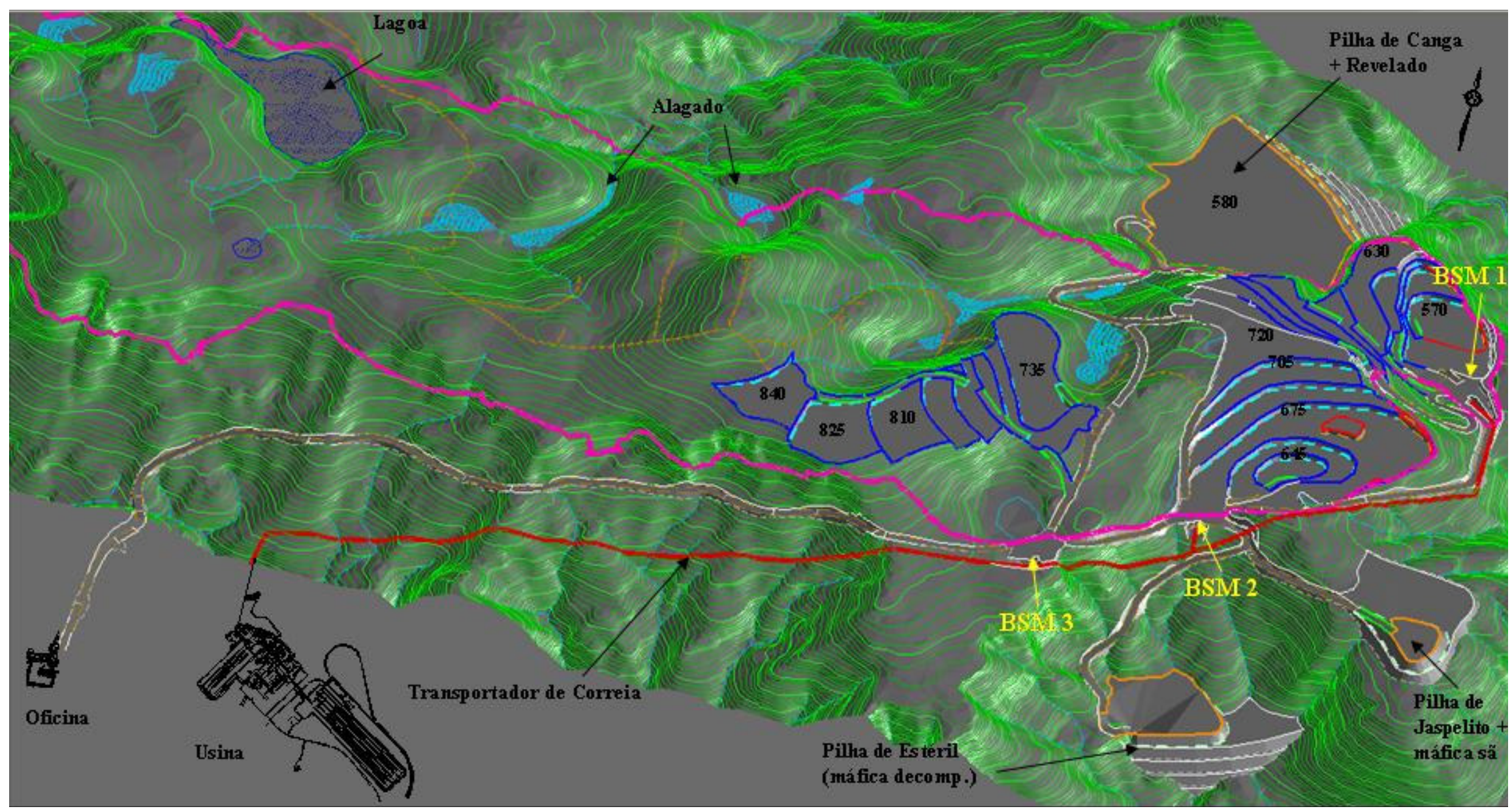

Figura 48 - Croqui sem escala do plano de lavra ano 02 (2012)

Fonte - Relatório Serra Sul Fel 3 - Relatório interno Vale, Mar/2008 


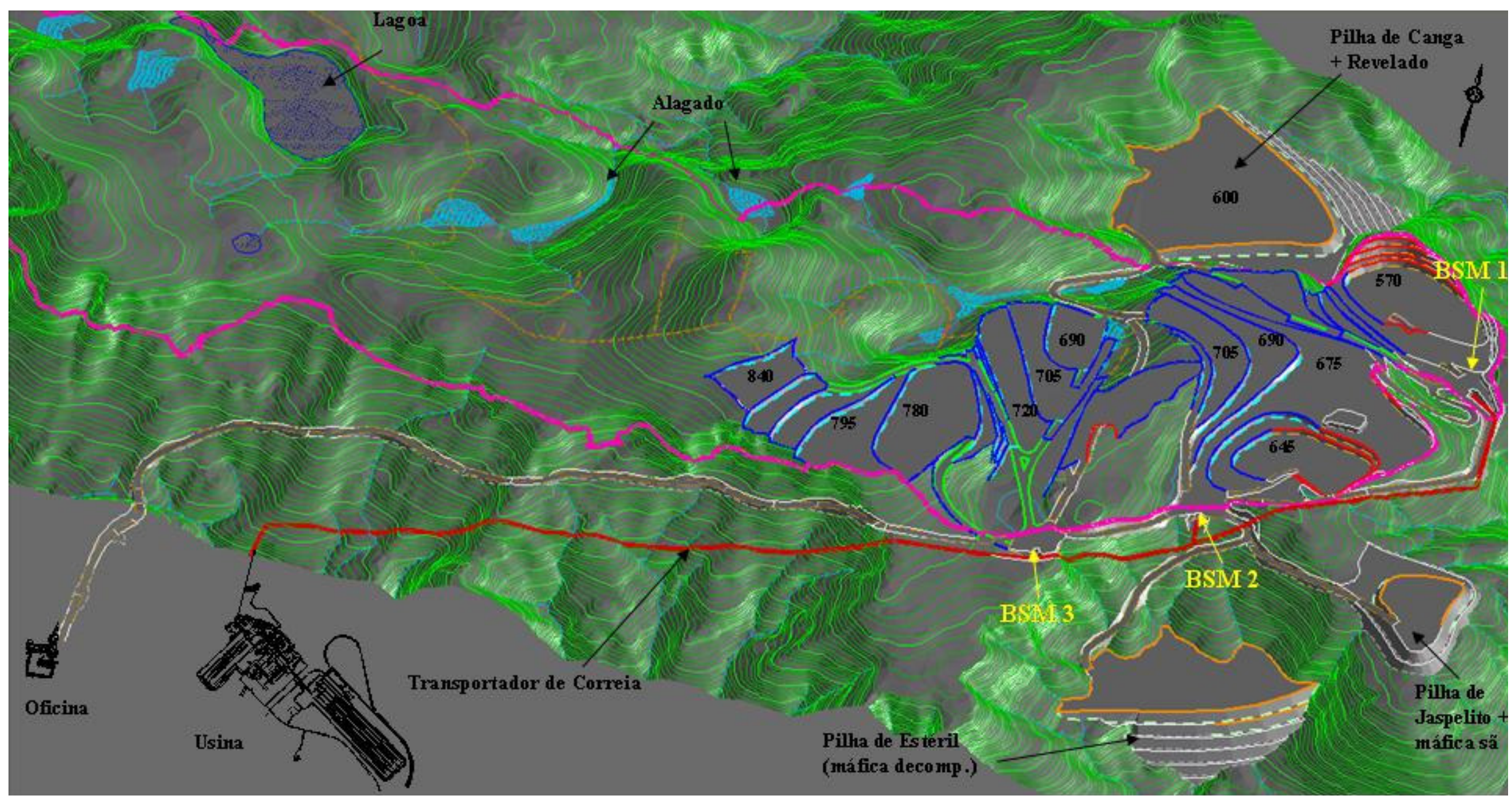

Figura 49 - Croqui sem escala do plano de lavra ano 03 (2013)

Fonte - Relatório Serra Sul Fel 3 - Relatório interno Vale, Mar/2008 


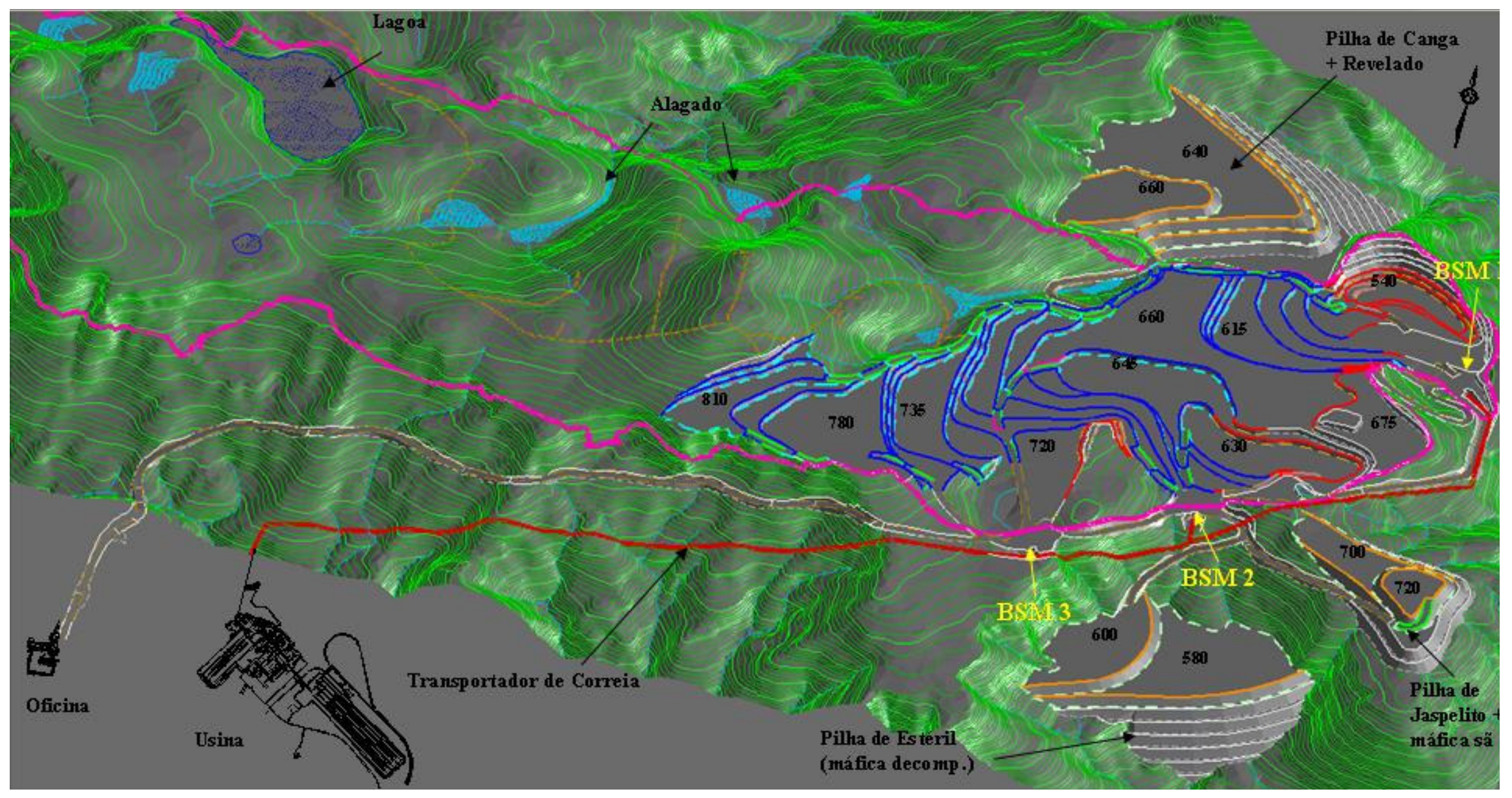

Figura 50 - Croqui sem escala do plano de lavra ano 05 (2015)

Fonte - Relatório Serra Sul Fel 3 - Relatório interno Vale, Mar/2008 


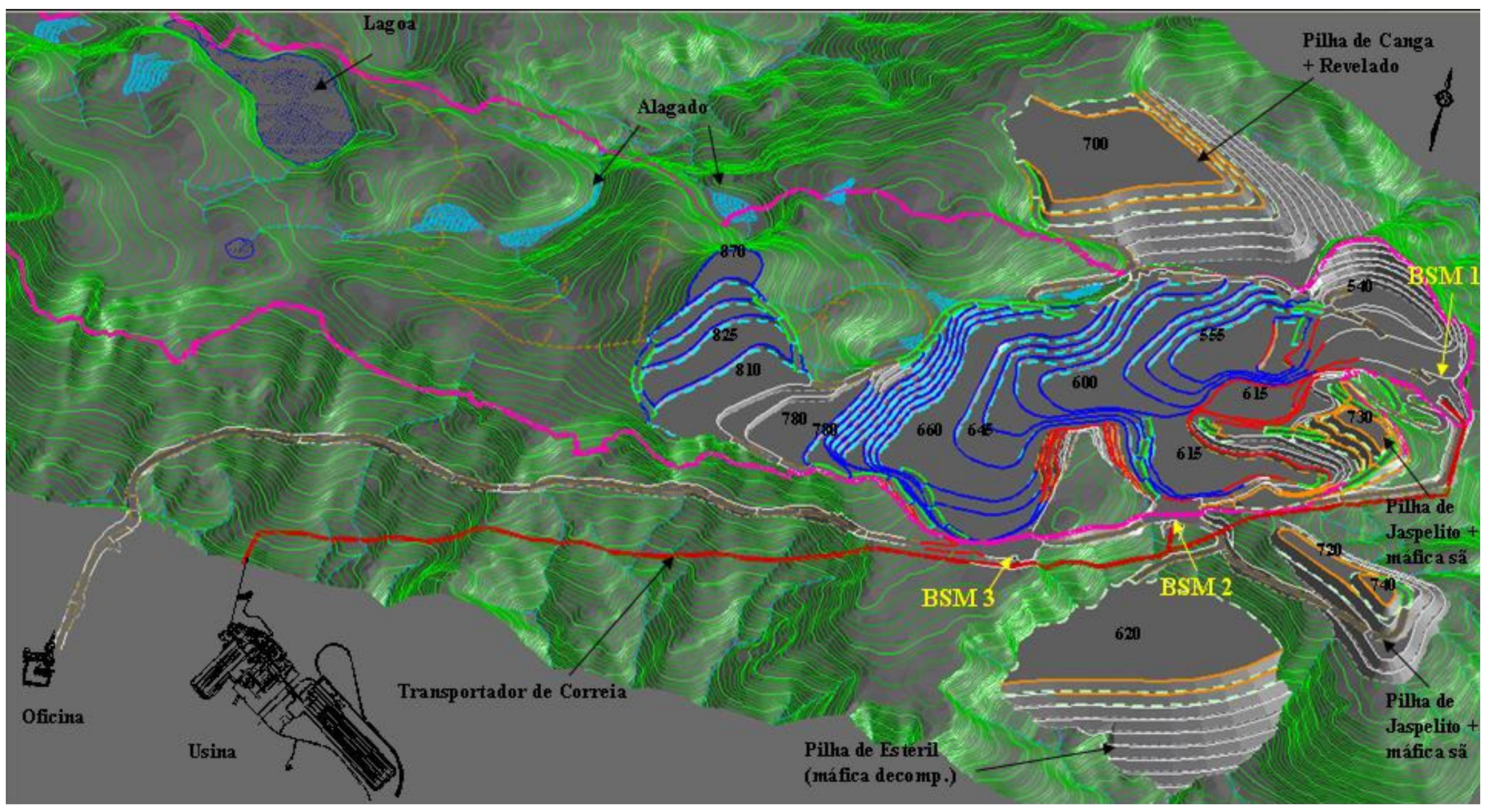

Figura 51 - Croqui sem escala do plano de lavra ano 07 (2017) Fonte - Relatório Serra Sul Fel 3 - Relatório interno Vale, Mar/2008 


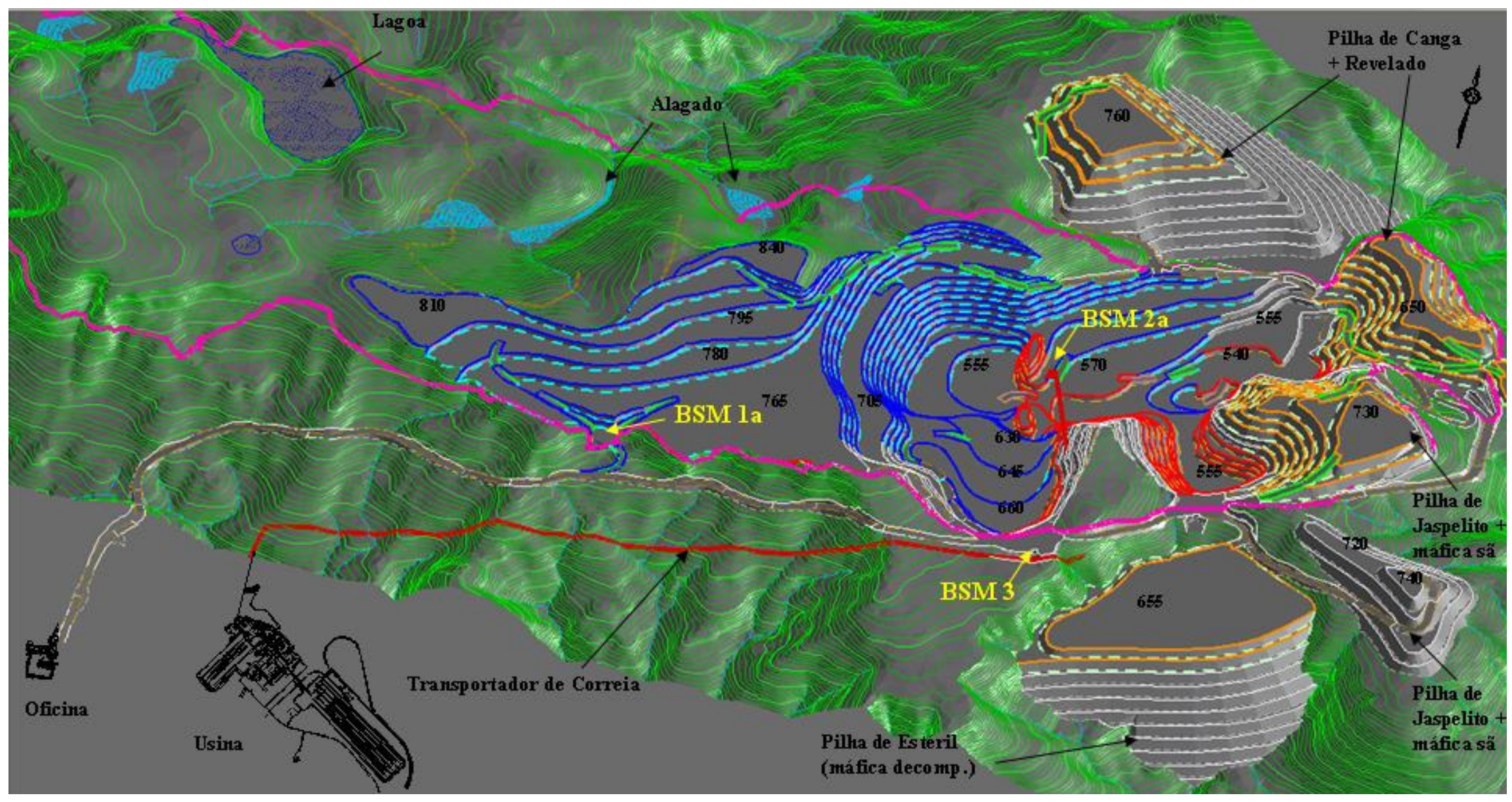

Figura 52 - Croqui sem escala do plano de lavra ano $10(2020)$ Fonte - Relatório Serra Sul Fel 3 - Relatório interno Vale, Mar/2008 


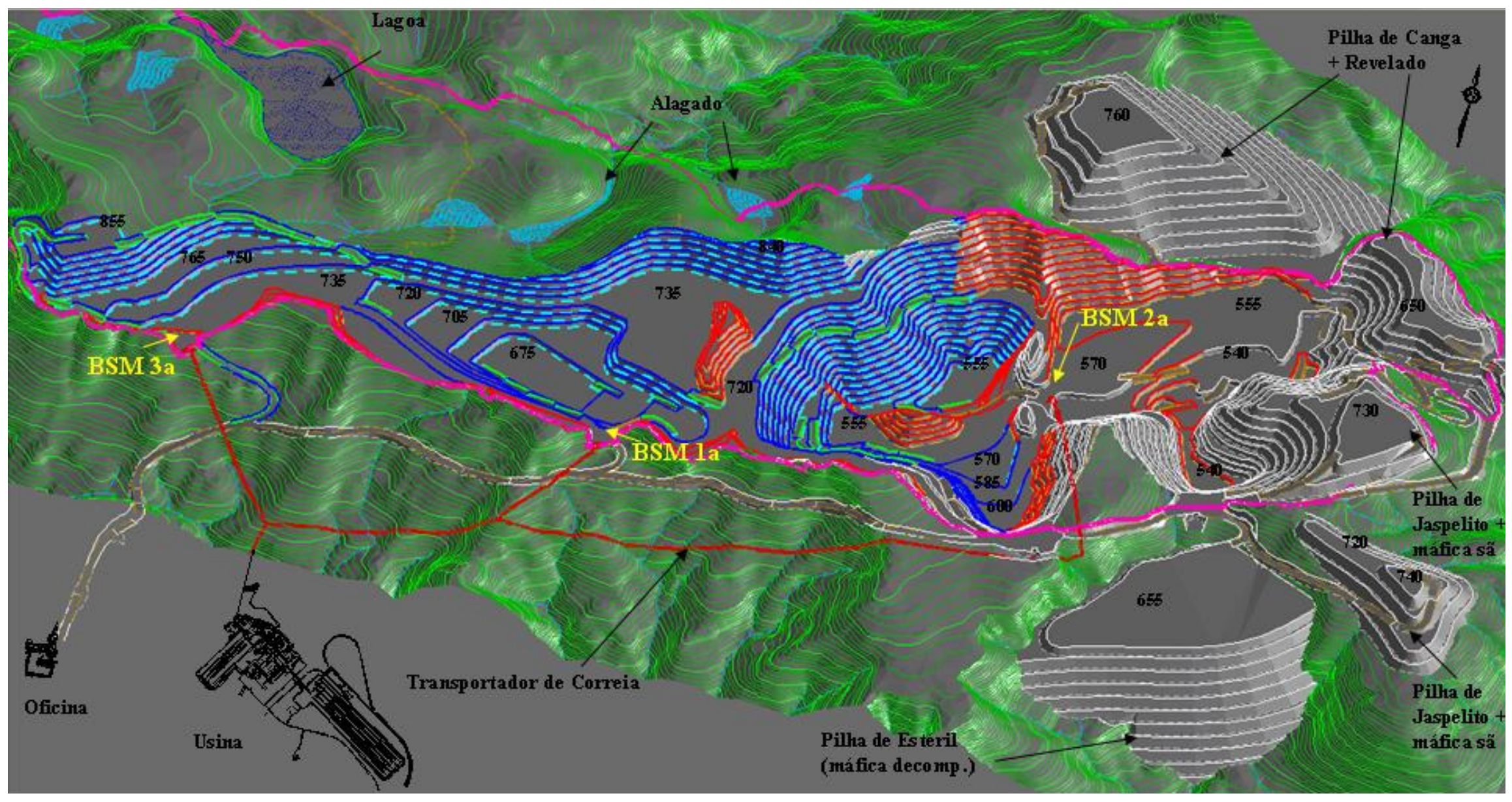

Figura 53 - Croqui sem escala do plano de lavra ano 15 (2025)

Fonte - Relatório Serra Sul Fel 3 - Relatório interno Vale, Mar/2008 


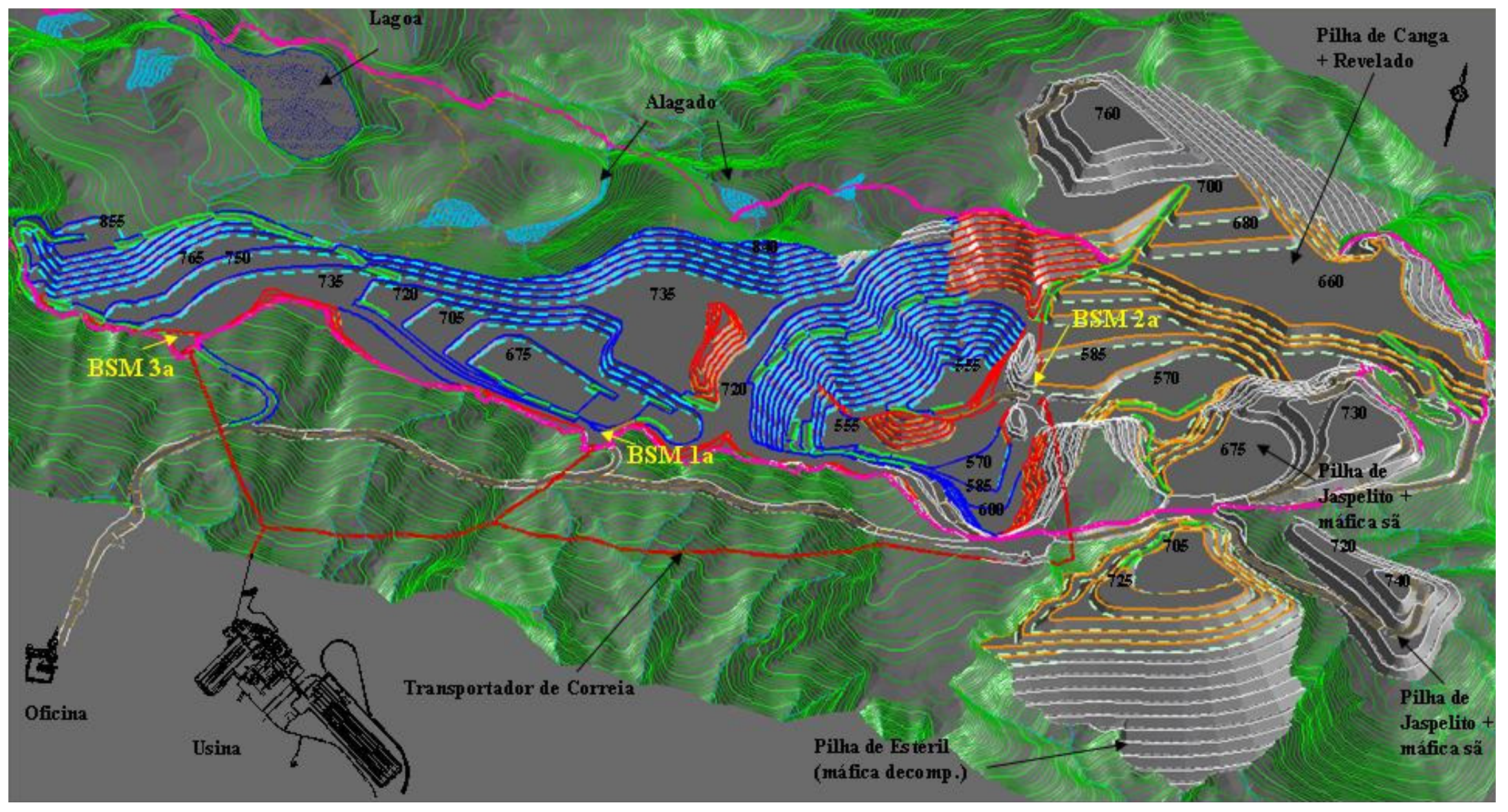

Figura 54 - Croqui sem escala do plano de lavra e disposição de estéril ano 15 (2025) Fonte - Relatório Serra Sul Fel 3 - Relatório interno Vale, Mar/2008 


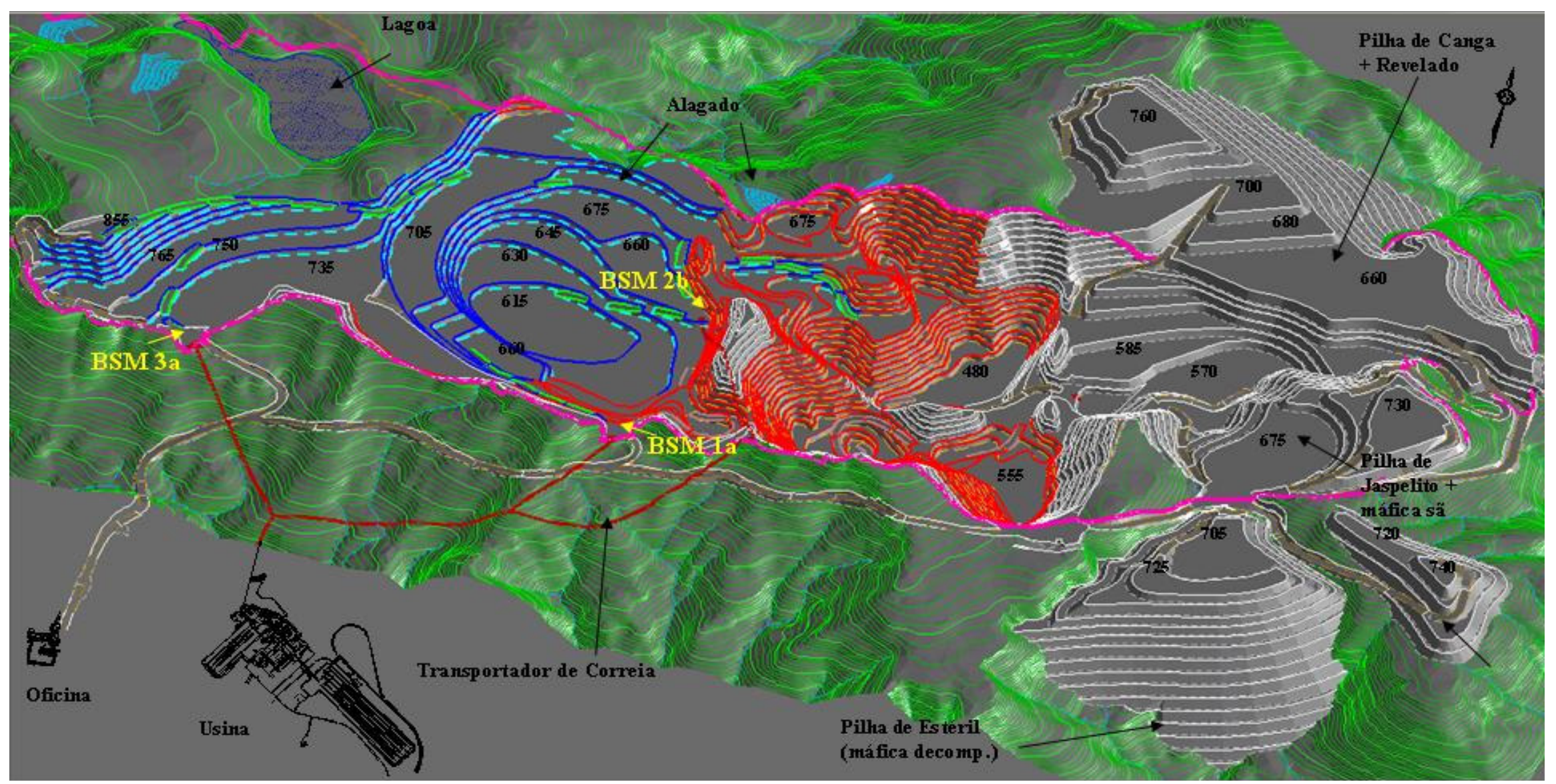

Figura 55 - Croqui sem escala do plano de lavra ano 20 (2030)

Fonte - Relatório Serra Sul Fel 3 - Relatório interno Vale, Mar/2008 


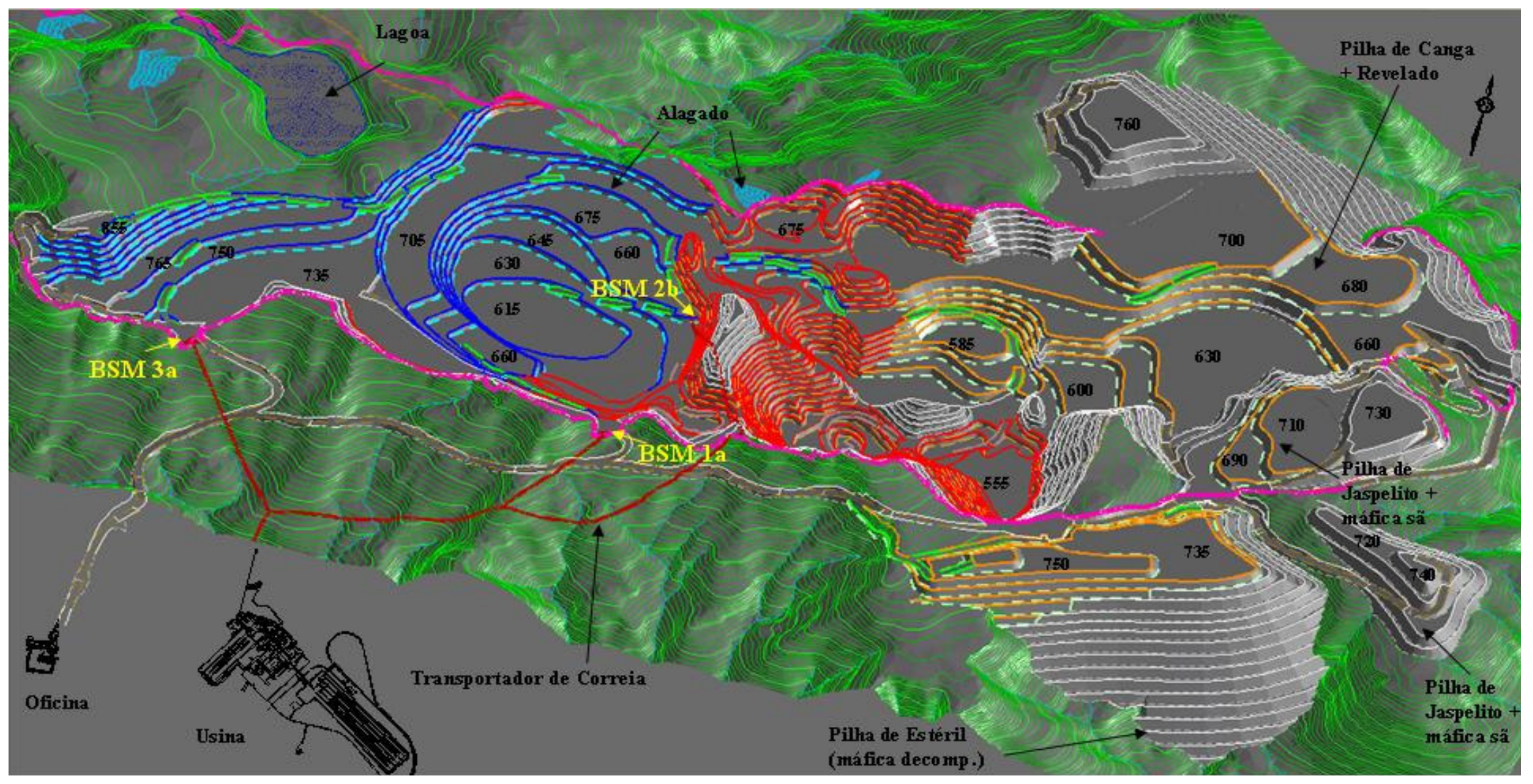

Figura 56 - Croqui sem escala do plano de lavra e disposição de estéril ano 20 (2030) Fonte - Relatório Serra Sul Fel 3 - Relatório interno Vale, Mar/2008 
